FACULDADE DE EDUCAÇÃO

UNIVERSIDADE DE SÃO PAULO

\title{
SABERES DOCENTES PEDAGÓGICOS \\ COMPUTACIONAIS E SUA ELABORAÇÃO NA PRÁTICA
}

(versão corrigida)

HELDER ANTONIO DE FREITAS

SÃO PAULO

2012 


\author{
FACULDADE DE EDUCAÇÃO \\ UNIVERSIDADE DE SÃO PAULO
}

\title{
SABERES DOCENTES PEDAGÓGICOS COMPUTACIONAIS E SUA ELABORAÇÃO NA PRÁTICA
}

\section{HELDER ANTONIO DE FREITAS}

\author{
Orientadora:
}

Prof. Dra. Maria Lucia Vital dos Santos Abib

Dissertação apresentada à Faculdade de Educação da Universidade de São Paulo, como exigência parcial para a obtenção do título de Mestre em educação em ensino de ciências. Área de concentração: Ensino de Ciências e Matemática.

\section{SÃO PAULO}


AUTORIZO A REPRODUÇÃO E DIVULGAÇÃO TOTAL OU PARCIAL DESTE TRABALHO, POR QUALQUER MEIO CONVENCIONAL OU ELETRÔNICO, PARA FINS DE ESTUDO E PESQUISA, DESDE QUE CITADA A FONTE.

Catalogação na Publicação

Serviço de Biblioteca e Documentação

Faculdade de Educação da Universidade de São Paulo

371.369 Freitas, Helder Antonio de

F866s Saberes docentes pedagógicos computacionais e sua elaboração na prática / Helder Antonio de Freitas; orientação Maria Lucia Vital dos Santos Abib. São Paulo: s.n., 2012.

116 p. ils.; tabs.; anexos

Dissertação (Mestrado - Programa de Pós-Graduação em Educação. Área de Concentração: Ensino de Ciências e Matemática) - - Faculdade de Educação da Universidade de São Paulo.

1. Tecnologia da informação 2. Tecnologia da comunicação 3. Formação de professores 4. Saberes do docente I. Abib, Maria Lucia Vital dos Santos, orient. 
Nome: Freitas, Helder Antonio de

Título: Saberes docentes pedagógicos computacionais e sua elaboração na prática.

Dissertação apresentada à Faculdade de Educação da Universidade de São Paulo com vistas à obtenção do título de Mestre em Educação.

Aprovado em:

\section{Banca Examinadora}

Prof. (a) $\operatorname{Dr}(\mathrm{a})$. : Instituição:

Julgamento: Assinatura:

Prof. (a) $\operatorname{Dr}(\mathrm{a})$ : Instituição:

Julgamento: Assinatura:

Prof. (a) Dr(a).: Instituição:

Julgamento: Assinatura: 
Dedicatória

Primeiramente a Deus.

Que me ilumina me guia e me protege pelas estradas tortuosas da vida.

Para meu pai Antonio, minha mãe Cícera e meu irmão Helber.

Pelo forte sentimento que nos une, com os quais iniciei meus estudos, aprendendo a amar os livros, a vida e ao próximo.

\section{À Graciele, pelo tempo que esteve ao meu lado.}

Com amor, admiração e gratidão por sua paciência, carinho, apoio e incentivo durante a elaboração deste trabalho, sempre presente, dividindo as dificuldades e alegrias da vida em comum.

Aos meus filhos, Thais, Bruno, Jessica e Thamires.

Pelo sentido que dão à minha vida.

Ao meu amigo Arnaldo.

Ao qual agradeço a confiança e contribuições prestadas, para a conquista da conclusão deste trabalho, na figura do qual agradeço a todos os outros que me apoiaram.

\section{Aos professores da Escola de Aplicação.}

Que me ajudaram com seus depoimentos para a elaboração deste trabalho. 
Agradecimentos

À Profa. Dra. Maria Lúcia Vital dos Santos Abib, minha professora orientadora, pela excelente orientação, por todo conhecimento compartilhado, pela confiança dedicada a mim e ao meu trabalho por todos esses anos, pelo incentivo, pelo apoio, pelas críticas, pelo cuidado, pelo compromisso, enfim, por tudo que tem me ensinado sobre a pesquisa e sobre a vida.

Aos colegas do Grupo de Pesquisa: Leonardo, Alexander, Nizete, Monica, Yara, Marta, Viviane, Rosana, Ariane e Beatriz; amigos-irmãos da jornada acadêmica, por tudo que compartilhamos e aprendemos juntos.

Aos professores da Escola de Aplicação da Universidade de São Paulo: Maíra, Fernanda, Lilian e Nelson, pelo tempo disponibilizado. 
Toda pessoa sempre é a marca de muitas, outras diferentes pessoas. E é tão bonito quando a gente sente que a gente é tanta gente onde quer que a gente vá. E é tão bonito quando a gente entende que nunca está sozinho por mais que pense estar. 


\section{RESUMO}

FREITAS, H. A. de. Saberes docentes pedagógicos computacionais e sua elaboração na prática. 2012. 116f. Dissertação (Mestrado) apresentada à "Faculdade de Educação da Universidade de São Paulo”, São Paulo, 2012.

A presente pesquisa está inserida no contexto de investigação da prática docente de professores de Ciências e Física e tem por objetivo verificar como os Artefatos Computacionais podem ajudar o professor no seu trabalho e, principalmente, como essa tecnologia pode auxiliá-lo a elaborar novos saberes sobre a docência. Para fundamentação do nosso estudo, recorremos às concepções de saberes desenvolvida por Tardif, às concepções de mediação de Vygotsky e trabalhos de diversos autores sobre o uso pedagógico do computador. Este trabalho desenvolveu-se na Escola de Aplicação da USP, cuja estrutura escolar muito contribuiu para a coleta dos dados verificados, por meio de entrevistas e observações das aulas dos professores de Física, Química, Biologia e Ciências, professores estes, com formação em Mestrado e Doutorado. Os resultados obtidos revelaram que os professores, fazendo uso de Artefatos Computacionais como recurso didático, ampliam os saberes que denominamos Saberes Docentes Pedagógicos Computacionais (SDPC) de natureza dos saberes Experienciais que, devido à sua abrangência, subcategorizamos em: do Uso dos Recursos, da Comunicação, da Busca Digital e do Compartilhamento Digital. Esses saberes identificados, categorizados e descritos por nós foram desenvolvidos e aprimorados pelos professores devido à prática pedagógica cotidiana que exercitam usando essa tecnologia, o que propicia interações entre professores e alunos e, de fato, conforme mostraram os dados, esses artefatos são utilizados como instrumento de mediação entre a ação pedagógica dos professores e o aprendizado dos alunos. Nesse processo de ensino, o sujeito principal é o professor e, por essa razão torna-se necessário investir no processo de formação inicial e continuada desse profissional, com o objetivo que não deve se limitar apenas à criação de condições para que o educador domine o uso dessa tecnologia, mas que ele seja capacitado para a utilização pedagógica dessa Ferramenta Cultura, proporcionando condições para que ele desenvolva saberes que possam ser aplicados na sua realidade de sala de aula, conforme as necessidades de seus alunos e os seus objetivos pedagógicos.

Palavras Chaves: Tecnologia da informação e comunicação, formação de professores, saberes docentes. 


\begin{abstract}
FREITAS, H. A. of. Teacher knowledge and providing a educational computing in practice. 2012. 116f. Thesis (Mestrado) presented to "Faculdade de Educação da Universidade de São Paulo”, São Paulo, 2012.

This research is research into the context of the teaching practice of teachers of physics and science and aims to verify how the Computer Artifacts can help the teacher in his work and especially how this technology can help you develop new knowledge about teaching. For reasons of our study, we use the concepts of knowledge developed by Tardif, the concepts of mediation of Vygotsky and works of various authors on the pedagogical use of the computer. This work was developed at the School of Application of USP, whose school structure has contributed to the collection of verified data, through interviews and observations of classroom teachers in Physics, Chemistry, Biology and Science, these teachers with training in Masters and $\mathrm{PhD}$. The results revealed that teachers, using Computational Artifacts as a teaching resource, expand the knowledge we call Teachers Pedagogical Knowledge Computing (TPKC) Experiential knowledge of nature which, because of its scope, in sub categorize: the Use of Resources, the Communication, Search Digital and Share Digital. This knowledge identified, categorized and described by us were developed and refined by teachers due to the daily practice that exercise using this technology, which facilitates interactions between teachers and students and, in fact, as shown by the data, these artifacts are used as instrument mediation between the pedagogical action of teachers and student learning. In the process of teaching, the main subject is the teacher and for that reason it becomes necessary to invest in the process of initial and continuing training of professionals, with the goal that should not be limited only to the creation of conditions for which the teacher dominates the Using this technology, but he is able to use this educational tool culture, providing conditions for it to develop knowledge that can be applied in their reality of the classroom, according to the needs of their students and their educational goals.
\end{abstract}

Keywords: Information technology and communication, teacher training, teacher knowledge. 


\section{SUMÁRIO}

Introdução

Capítulo I - Problemas atuais no ensino de Ciências

8

Capítulo II - Novas tecnologias no ensino de Ciências: Artefatos Computacionais, Professor e Aluno

2.1 Mediação: Professor - Artefatos Computacionais - Aprendizagem

2.2 Artefatos Computacionais: sua importância para o ensino-aprendizagem e as necessidades para a formação de professores

2.3 Modos de utilização dos Artefatos Computacionais

2.3.1 Uso da Modelagem Computacional

2.3.2 Uso da Multimídia Computacional

2.3.3 Uso da Internet

$2.4 \quad$ Objetos Virtuais de Aprendizagem …….................................................. 36

Capítulo III - Saberes Docentes e Formação de Professores ....................................... 39

Capítulo IV - Metodologia de pesquisa …................................................................ 49

4.1 Metodologia qualitativa

4.2 Sujeitos da pesquisa

4.3 Método de coleta de dados .................................................................... 55

4.4 Organização dos dados para análise ........................................................ 56

Capítulo V - Analise dos dados

5.1 Categorias de pesquisa

5.1.1 Saberes Docentes Pedagógicos Computacional de Formação Profissional

5.1.2 Saberes Docentes Pedagógicos Computacionais Disciplinares.

5.1.3 Saberes Docentes Pedagógicos Computacionais Curriculares ................ 61

5.1.4 Saberes Docentes Pedagógicos Computacionais Experienciais 
5.2 Saberes Docentes Pedagógicos Computacionais Experienciais do Uso dos Recursos

5.3 Saberes Docentes Pedagógicos Computacionais Experienciais da Comunicação... 72

5.4 Saberes Docentes Pedagógicos Computacionais Experienciais da Busca Digital... 73

5. Saberes Docentes Pedagógicos Computacionais Experienciais do Compartilhamento Digital .

Capítulo VI - Conclusões e considerações finais

Referências bibliográficas

Bibliografia consultada

Anexo 1 - Roteiro de Entrevista

Anexo 2 - Análise dos Dados das Quatro Entrevistas Realizadas e das Observações em Sala de Aula 


\section{Introdução}

Os conteúdos propostos para a disciplina de Ciências são considerados por professores e principalmente por alunos como sendo de difícil compreensão e os alunos, de certa forma, apresentam dificuldades no entendimento dos fenômenos físicos, dos modelos matemáticos e das fórmulas envolvidas. A excessiva valorização pela utilização direta de fórmulas na representação de fenômenos físicos, decorando-as sem a devida compreensão quanto a sua origem e/ou finalidade, pode trazer dificuldades para o aluno construir suas próprias hipóteses e conclusões acerca de determinados conteúdos. Por outro lado, existe a necessidade de formar cidadãos politicamente críticos e participativos em discussões públicas sobre assuntos importantes relacionados com a ciência e com a tecnologia, tornando-os potencialmente capazes para tomar decisões e compreender a natureza e o mundo tecnológico que os envolvem. Como afirma Cachapuz e outros:

A participação dos cidadãos na tomada de decisões é hoje um fator positivo, uma garantia de aplicação do princípio de precaução, que se apoia numa crescente sensibilidade social face às aplicações do desenvolvimento tecnocientífico que pode comportar riscos para as pessoas ou para o meio ambiente (CACHAPUZ, 2005, p.28).

Um dos recursos didáticos que pode ser utilizado como tentativa para amenizar estes problemas é a telemática ${ }^{1}$. Os diversos modos de utilização do computador podem contribuir para a diversificação de estratégias no ensino. O professor dispõe de novas possibilidades para favorecer a construção do conhecimento e apresentar aos alunos uma variedade de meios, utilizando uma ferramenta que atraia os jovens, principalmente aqueles que já têm contato com essa tecnologia em seu cotidiano.

Existem algumas pesquisas que enfocam o uso dos recursos computacionais como ferramenta educacional no ensino de Ciências, mas o que se vê em algumas escolas é que tais recursos não são utilizados e, quando o são, nem sempre se realizam de forma adequada, ou seja, não se direcionam à busca da construção do conhecimento e sim, como uma metodologia de ensino que não consegue ultrapassar os procedimentos tradicionais de pura transmissão de conhecimento. Muitas vezes, o computador é usado para simples transferência de conteúdos

${ }^{1}$ Telemática consiste num conjunto de tecnologias de informação e de comunicação resultante da junção entre os recursos das telecomunicações com os computacionais, possibilitando o processamento, a comprenssão, o armazenamento e a comunicação de grandes quantidades de dados, nos formatos texto, imagem e som, em curto prazo de tempo, entre usuários localizados em qualquer ponto do Planeta. 
de livros didáticos e de outras formas de utilização que não têm qualquer significado para o aluno e não lhe acrescenta nada.

O computador pode ser uma ferramenta que disponibiliza ao professor uma quantidade significativa de recursos e que também o auxilie no processo de ensino e aprendizagem. Na geração atual de alunos, por sua vez, entre aqueles que possuem a oportunidade de ter contato frequentemente com essa ferramenta, há os que o fazem apenas para interagir com outras pessoas e para procurar conhecimentos de seu interesse. Os recursos que a rede mundial de computadores oferece fazem com que os jovens naveguem na internet, comuniquem-se com amigos através de blogs, páginas de relacionamento e outros. Em geral, os alunos do Ensino Fundamental e Médio possuem uma grande facilidade para realizar atividades com o uso de computadores, podendo ser também utilizado para a busca da aprendizagem com a orientação do professor.

A riqueza dos recursos telemáticos não substitui a presença e a ação do professor, pois há a necessidade de orientação e de direcionamento do uso desses recursos para as atividades de ensino, de modo que leve os alunos à construção do conhecimento sem se dispersarem neste universo de informações. Nesse sentido, cabe ao professor ficar atento ao fato de que muitos dados e informações não significam necessariamente maior e melhor conhecimento, e seu desafio está em selecionar as informações verdadeiramente importantes entre tantas e torná-las significativas.

A presença e o uso do computador nas escolas podem levar alguns alunos à euforia e, por outro lado, observa-se a resistência de alguns professores, principalmente daqueles que, por não estarem familiarizados com essa ferramenta, não imaginam o quanto podem explorar desse recurso didático. A inclusão de computadores nas escolas com sua efetiva utilização para o aprendizado, não apenas centrado na transmissão de conhecimentos, como ocorre com transição de paradigma, pode gerar uma resistência devido à complexidade do seu uso como recurso pedagógico, o que requer dos professores uma formação específica, pois a maioria deles está acostumada a um método tradicional de ensino que vêm praticando ao longo dos anos. Há, entretanto, também professores que se preocupam com a aprendizagem na perspectiva da construção do conhecimento, estimulando a pesquisa, a investigação, a imaginação e a criatividade e não se opõem à inclusão didática dos computadores. Em relação a essas perspectivas, Cunegatti destaca que: 
Os alunos, quando têm aulas com auxílio do computador, se mostram eufóricos e não vêem a hora de chegar à esperada aula, sendo que neste dia a assiduidade é visivelmente maior por ser uma aula divertida para eles, levando-os a interagirem com seus colegas, não percebem o tempo passar e, com o decorrer das aulas, passam a realizar suas atividades de modo autônomo, assumindo o professor o papel de mediador. O universo escolar tende a ser mais prazeroso ao aluno, dependendo de cada circunstância e da perspectiva que cada um constrói em relação a este contexto. (CUNEGATTI, 2004, p.72)

Alguns professores tiveram sua formação, suas vivências e experiências baseadas numa pedagogia tradicional e estão acostumados a ela dominando-a muito bem. Desta forma, quando se embrenham numa área totalmente desconhecida é natural que ofereçam resistência ao novo. Para que uma proposta pedagógica seja significativa para o professor, ele precisa ter consciência da necessidade de mudanças e da inserção de novas tecnologias em suas práticas pedagógicas. É necessário ter consciência da potencialidade que existe tanto no computador como nele próprio sendo que essa máquina só será útil pedagogicamente, se contar com a orientação do professor.

Há os que pregam que com a introdução do computador nas escolas, a instituição de ensino estará fadada a ter seu fim decretado e o aluno será um estudante solitário. Mas a simples existência dessas novas tecnologias num processo didático-pedagógico não torna para o aprendiz o processo de ensino mais rico, estimulante, desafiador e significativo sem a orientação do professor. É a ação do professor que adequa o uso pedagógico destas novas tecnologias e, se assim não for, pode resultar na permanência na metodologia tradicional de ensino, mesmo utilizando essas novas tecnologias. Cabe ao professor mediar o processo de construção de conhecimentos, estimulando e promovendo desafios junto aos alunos. Transmitir informações, ou coisa semelhante, já não deve ser mais o papel único do professor, mas sobretudo construir ambientes de aprendizagem com os inúmeros meios didáticos que o computador oferece. Diante de informações acessadas pelos alunos nas redes de comunicação, cabe ao professor, pedagogicamente, enriquecê-las, atribuindo-lhes significados, relacionando-as com outros conteúdos, com a cultura dos discentes e com suas experiências de vida.

O universo dos recursos telemáticos está transformando rapidamente o mundo em que se vive e a escola necessita reorganizar-se e reinventar-se para que as novas tecnologias, mais especificamente o computador, tragam contribuições significativas para a aprendizagem. Além disso, a escola deve estar preparada para formar cidadãos capacitados para atuar neste mundo computacional. O uso do computador está presente em toda a sociedade e é natural 
que a escola venha a adotá-lo efetivamente nos processos de ensino e de aprendizagem. A razão para obterem-se resultados significativos pode estar na reinvenção da escola, deixando de ser o giz e a lousa o seu referencial, transformando a sala de aula em um espaço prazeroso de construção de conhecimentos que transcenda seus muros e neste intento, pode o computador e seus recursos computacionais ser de grande valia.

Dessa forma, no processo de aprendizagem, a construção individual ou coletiva de conhecimentos requer do professor muito mais do que conhecimentos teóricos e tecnológicos e de que seja ele um agente disseminador de informações, requer do professor que ele esteja receptivo deixando o aluno expor suas ideias e trilhar seus próprios caminhos. Como mediador do processo educacional, o professor deve estar atento para as vantagens, desvantagens, facilidades, dificuldades e possibilidades que esses recursos tecnológicos podem proporcionar ao processo educativo.

O uso pedagógico do computador pode contribuir com o professor para torná-lo parceiro de seus alunos no processo de aprendizagem, mudando o foco da ênfase no ensinar para a ênfase no aprender. Esse processo pode propiciar para aqueles docentes que só reproduzem os conhecimentos, uma oportunidade para que passem a abrir caminhos coletivos, tanto para os alunos quanto para ele professor na busca, investigação e produção do conhecimento. O aluno, por sua vez, pode passar a ser menos passivo, só escutando, lendo, decorando e repetindo fielmente os ensinamentos do professor, para tornar-se criativo, crítico e atuante na produção de seus conhecimentos pessoais.

Durante cinco anos lecionando a disciplina de Física em escolas públicas do Estado de São Paulo, pude observar que algumas dessas escolas possuíam laboratórios de informática, mas não eram utilizados devido ao fato de não haver professores capacitados para tal, e nas escolas que existiam esses docentes, eles o faziam com ênfase em ensinar os alunos apenas a manusearem a máquina sem pensar no processo educativo. Esse fato me leva a pensar que deva ser em uma minoria de escolas que esses dois fatores apareçam agregados, ou seja, que possuam computadores e professores que saibam utilizá-los com o escopo de construir conhecimentos.

Não basta introduzir equipamentos e recursos tecnológicos na escola sem que os professores reflitam e alterem suas práticas. É justamente o movimento oposto que precisa ocorrer: é necessário que os professores reflitam e revejam suas práticas e sentindo a necessidade, reclamem a introdução desses equipamentos. Além disso, é mais importante a 
maneira como a tecnologia é utilizada do que simplesmente ela estar disponível na sala de aula ou na escola, pois o valor da tecnologia na Educação é derivado inteiramente da sua aplicação (HEIDE e STILBORNE, 2000). Sobre esse aspecto, Nascimento (2001) afirma que: “... nada adianta ter escola informatizada se não existirem professores capazes de entender o grande desafio de pensar e agir sobre uma nova lógica”. (p. 60-61)"

Para que o uso do computador garanta o ensino e a aprendizagem, faz-se necessário que todos que façam parte da escola, alunos, professores e corpo administrativo, saibam adequadamente explorar os recursos existentes nesses equipamentos. Os computadores podem ser programados para serem utilizados com diversas finalidades, tais como: máquina de escrever, base de dados, tutor de estudos, meio de comunicação entre pessoas, além de outros. O limite de sua utilização está na criatividade humana e cabe à escola como um todo buscar a melhor adequação desses equipamentos, programando-os para atender aos objetivos pedagógicos. Para tanto, faz-se necessário conhecer métodos e processos relativos à atividade escolar para que o uso dessas máquinas seja otimizado no processo de educar. Cox, sobre esse aspecto, defende que:

[...] o número de formas de uso dos Computadores tem seu limite nas fronteiras da capacidade criadora do homem, ou seja, as várias formas de uso dos computadores no contexto escolar estão diretamente atreladas ao potencial criativo do ser humano tais como: a simulação, os jogos, a comunicação, o ensino à distância, os programas comerciais e os programas ou softwares, além da modelagem computacional e da Internet (COX, 2003, p. 35).

No ano de 2007, realizamos um trabalho de monografia intitulado "A Motivação do Aluno e as Novas Tecnologias Computacionais no Ensino de Física”. Nesse trabalho, o referencial teórico adotado trazia estudos sobre a motivação do aluno e sobre a utilização de meios computacionais como instrumento pedagógico. Trabalhamos com a motivação do aluno segundo o referencial de BORUCHOVITCH e BZUNECK (2001), que define três Metas de Realizações Motivacionais: Meta Aprender, Meta-Performance-Aproximação e MetaPerformance Evitação, sendo que esta sequência está numa escala decrescente, do mais motivado para o menos motivado.

Esta pesquisa teve como alicerce a hipótese de que as tecnologias computacionais, como um importante instrumento pedagógico e motivador, poderiam, em determinadas atividades no ensino de Física, mudar a percepção de um aluno orientado para a MetaPerformance-Evitação para, quem sabe, a Meta-Aprender. Após a aplicação de uma atividade 
com auxílio pedagógico do computador, verificou-se que o número de alunos orientados à Meta-Aprender aumentou de $41 \%$ para $63 \%$, os orientados à Meta-Performance Aproximação aumentou de $15 \%$ para $19 \%$ e os orientados à Meta-Performance Evitação caiu de $44 \%$ para $19 \%$, o que demonstra que, de uma forma geral, houve uma mudança positiva com os alunos quanto às Metas de Realização.

No final, foram pesquisados três alunos que indicavam ser orientados para a Meta-Performance Evitação e a atividade pedagógica proposta para eles, com a utilização do computador, realmente trouxe melhorias no perfil motivacional no momento de sua realização. O que não se pode afirmar é que o uso pedagógico exclusivo do computador seja o único meio didático existente que possa propiciar essa melhoria, mas sim que há a possibilidade de que qualquer outra atividade que fuja de aulas com metodologias tradicionais, expositivas, monótonas, sem participação dos discentes, em que o professor fala e o aluno escuta, possa vir a causar tal melhoria.

Os argumentos até aqui apresentados remeteram-nos ao presente trabalho de Mestrado com o objetivo de pesquisar professores da educação básica que utilizem o computador no seu trabalho docente e de verificar como eles desenvolvem seu trabalho com o uso desse equipamento, analisando as vantagens e desvantagens, os riscos e benefícios nos processos de ensino e aprendizagem. Desta forma, uma questão importante é investigar até que ponto a introdução dessa ferramenta pode auxiliar o professor a melhorar seu trabalho e, mais especificamente, em que medida pode auxiliar o professor a elaborar novos saberes sobre a docência, sendo que para tal, vamos procurar responder ao seguinte problema:

“Que saberes docentes, relativos ao uso dos Artefatos Computacionais, são elaborados pelos professores a partir de sua utilização em sua prática docente”?

Os dados foram analisados e interpretados sob uma perspectiva qualitativa e teve como alicerces referenciais teóricos os que discutem as questões dos saberes docentes, o uso pedagógico do computador e as relações de mediação. Nesse sentido foram adotados os pressupostos de Vygotsky com sua teoria de mediação, sendo que consideramos os Artefatos Computacionais como uma Ferramenta Cultural que é ao mesmo tempo, instrumento com signo e de Tardif (2002) com sua teoria de elaboração de saberes docentes que os classifica em conhecimentos profissional, disciplinar, curriculares e experienciais. A partir dessa classificação de saberes, criamos nossas categorias de análise dos Saberes Docentes Pedagógicos Computacionais (SDPC). Quanto ao uso pedagógico do computador, nos 
ancoramos em Fiolhais \& Trindade (2003), Nunes (2011) entre outros autores. Desses autores citados, criamos nossas categorias de modos de utilização dos artefatos computacionais como sendo as de Modelagem Computacional, Multimídia Computacional e Internet.

A presente pesquisa, além de buscar respostas para o problema que a norteia, procura ainda contribuir para entendermos até que ponto o uso de artefatos computacionais por professores em seu trabalho docente contribui para a elaboração de novos saberes pedagógicos e apontar a necessidade da introdução do computador nas escolas como ferramenta pedagógica. Dessa forma, a hipótese seria a de minimizar os efeitos de resistência a essa mudança de paradigma, ou seja, a mudança de uma escola que tenha como referência o giz e a lousa para uma que tenha o computador e seus recursos como alguns de seus ícones. A ideia é de que não pode falar em escola sem que a ela estejam atreladas novas tecnologias, formando no professor a consciência da necessidade de sua utilização e que ele entenda a sua importância e a reivindique como sendo, entre outros aspectos pedagógicos, de uma importância significativa para o seu trabalho docente de mediação e orientação, e não simplesmente de divulgação de conhecimento.

Desta forma, nosso trabalho está assim organizado: O primeiro capítulo discute os problemas atuais no ensino de Ciências. Já o segundo capítulo, discute o uso dos Artefatos Computacionais no ensino de Ciências, seus modos de utilização, as interações mediadas por essa Ferramenta Cultural, sua importância para o ensino, necessidades para a formação de professores e sobre os Objetos Virtuais de Aprendizagem. O terceiro capítulo, aborda as concepções de saberes segundo Tardif (2002). O quarto capítulo, explana metodologia de pesquisa, o problema da pesquisa, as categorias criadas, o processo de coleta de dados e instrumentos utilizados para organização dos dados, e posteriores análises no quinto capítulo. Por último, o sexto capítulo, discute os resultados da pesquisa, as conclusões e considerações finais. 


\section{Capítulo I - Problemas atuais no ensino de ciências}

$\mathrm{O}$ aluno ao ter seu primeiro contato na área das ciências, principalmente com a disciplina de Física, normalmente não é com satisfação que o faz. Apesar de fazer parte do cotidiano da vida das pessoas, este ramo das ciências parece permanecer longe da escola devido a dificuldades de compreensão dos alunos. Este é um problema que muitos pesquisadores tentam desvendar frente a estudantes, pais e professores que demonstram desagrado com essa área do conhecimento, por considerá-la abrangente, perfeita e totalmente desvendada e, desta forma, de difícil compreensão. As ciências são apresentadas por professores aos alunos como sendo constituídas por regras infalíveis e os métodos científicos apresentam-se como uma sequencia rígida e lógica de passos e dessa forma, as ciências se tornam para os alunos uma barreira para o conhecimento. Klajn a este respeito afirma:

[...] ao ensinar ciências como produto resultante de uma metodologia rígida, indiscutivelmente verdadeira e definitiva, leva-se os estudantes a considerar o aprendizado da física difícil. Isso porque, ao receberem dessa forma a física, ou seja, ao apenas terem de reafirmar verdades inquestionáveis, eles retêm conhecimentos, mas não o fazem com significação. (KLAJN, 2002, p.88)

Segundo o autor, o ensinamento teórico transmitido no Ensino Médio tem por objetivo preparar os alunos para o ensino superior, não preparando para o trabalho e para a vida os que não ingressam em uma faculdade. Qualquer reforma deveria se preocupar não apenas com conteúdos, mas em diversificar a estrutura do ensino e com a preparação para a vida cotidiana. $\mathrm{O}$ autor realizou um trabalho com 36 alunos do Ensino Médio, com o intuito de descobrir como os estudantes dependentes e reprovados em Física no Ensino Médio veem essa disciplina. Ele identificou seis categorias que representam um empecilho para os alunos alcançarem uma aprendizagem significativa. A primeira diz respeito ao relacionamento professor/estudante em que os alunos apontam a falta de afetividade entre eles e o professor, o que gera, por exemplo, medo de perguntar. A segunda categoria diz respeito à atitude do estudante na sala de aula como: concentração, frequência, interesse e atenção, as quais prejudicam a sua aprendizagem em Física. A terceira categoria diz respeito à abrangência do conhecimento da Física, que é considerada pelos alunos como sendo uma ciência cheia de símbolos matemáticos, de conceitos químicos e procedimentos biológicos, de conhecimentos históricos e posturas políticas. A quarta categoria diz respeito à linguagem da Física que, por ser específica e estar baseada em operações aritméticas, é de difícil compreensão para o aluno. A quinta categoria diz respeito à postura metodológica de ensino e ao processo avaliativo da aprendizagem adotados pelos professores que não motivam, dificultam o desempenho e não 
despertam o interesse pela disciplina, principalmente devido ao uso sistemático do livro didático, à resolução mecânica de exercícios, à cópia do livro, ás aulas teóricas expositivas e repetitivas, aos métodos avaliativos como prova bimestral, entre outros aspectos. A sexta e última categoria, diz respeito ao mito de a Física de ser considerada difícil, já que os alunos não aprendem no contexto das suas manifestações da vida diária, canalizando-se o ensino para o vestibular e bloqueando-se qualquer tentativa de maior compreensão, interpretação e apropriação dos fenômenos físicos.

Analisando essas categorias, pode-se ver que são vários os motivos que levam à dificuldade no ensino-aprendizagem de Física como a imagem social da disciplina, o professor, o sistema de avaliação, a metodologia de ensino, as dificuldades e limitações específicas da disciplina, o querer do estudante, entre outros. A escola pode desenvolver a atenção e o pensamento reflexivo no aluno levando-o a construir, a pensar e a resolver situações problemáticas, já que é por meio da ativação dos processos mentais que o aluno chega à autoestruturação de conhecimentos significativos (KLAJN, obra citada).

De modo geral, adota-se para o ensino de Ciências uma metodologia tradicionalista, de caráter conteudista, que não favorece os alunos a desenvolverem o raciocínio abstrato e o observador, inerentes a essas disciplinas. Muitas vezes, as aulas são norteadas por livros didáticos e o que se exige dos alunos é a memorização de fórmulas e sua aplicação em problemas que não possuem nenhum sentido para a realidade deles (CACHAPUZ et al, 2005).

Por meio dos relatos de professores e da vivência em sala de aula, verifica-se o alto grau de desinteresse e de dificuldade demonstrados por alguns alunos, que se tornam fatores prejudiciais ao desenvolvimento cognitivo e geram desinteresse dos alunos principalmente pela disciplina de Física. As causas destes sentimentos nos alunos para com o aprendizado de Física, nos vários níveis de ensino, não estão devidamente esclarecidas segundo Fiolhais e Trindade (2003).

A abordagem tradicionalista é uma prática educacional que persiste até os tempos atuais e privilegia a relação de subordinação do aluno, os modelos pré-estabelecidos de ensino. Nessa abordagem, a reprovação do aluno é necessária quando este não assimila o mínimo necessário do proposto para a série em que se encontra. A prova é a ferramenta para que se faça essa mensuração e o diploma é a patente que o posiciona hierarquicamente na sociedade. A escola, por sua vez, é o lugar por excelência onde se realiza a transmissão do 
conhecimento e a sala de aula é o lugar onde os alunos são instruídos e ensinados pelos professores que se preocupam com quantidade e variedade de conceitos e informações, em detrimento da formação do pensamento reflexivo, predominando o verbalismo do professor: o sujeito que detém o poder, e a memorização do aluno: o sujeito submisso (MIZUKAMI, 2000).

Nessa perspectiva de aprendizagem, o resultado das avaliações é questionável, visto que sua precisão e objetividade têm duplo sentido, devido à margem de incerteza, sendo que não se mensura o aprendizado e sim os erros e acertos. A função essencial da avaliação, nesse contexto, é medir a capacidade e o aproveitamento dos alunos, destinando-lhes notas que sirvam para suas promoções.

O desinteresse dos alunos pode ser constatado, observando-se o menor número de alunos que se matriculam em cursos de nível superior nas disciplinas de ciências em comparação às outras áreas. Os alunos questionam a importância do que estão aprendendo e o interessante para eles é entender o mundo onde estão inseridos, com um estudo de ciências centrado em seus problemas e não voltado para um olhar de cientista. Os alunos têm consciência da importância da ciência para a humanidade e ficam maravilhados com as novidades tecnológicas e médicas, mas esses pontos não são fundamentais para despertar o interesse por essa disciplina (FOUREZ, 2003).

Os professores, por sua vez, possuem uma formação voltada para torná-los técnicos ao invés de educadores e não conseguem mostrar aos seus alunos o sentido de aprenderem Ciências. Este é um fator importante que dificulta a inovação do ensino de Ciências e o trabalho investigativo do professor, impedindo-o de trilhar caminhos que levem seus alunos a construirem o conhecimento e que não seja ele professor, apenas um transmissor dos conteúdos dos livros didáticos, principalmente quando não dominam o conhecimento da matéria e possuem um pensamento de senso comum. Pensamento esse que pode ter sido herdado de suas experiências quando alunos, época em que eram expectadores de seus professores e seus mestres os detentores de todo o conhecimento, que era transmitido por aulas expositivas, e agora ele como professor repete essa prática. Esse ensino embasado em aulas expositivas funciona como estímulo para que se torne um professor habituado a transmitir o conhecimento ao invés de ajudar a construí-lo (FOUREZ, 2004).

O necessário é haver cidadãos alfabetizados cientificamente, ou seja, conscientes do significado que a ciência e a tecnologia têm para a sociedade e que sejam capazes de 
participar de decisões e de utilizar seus conhecimentos no dia-a-dia, melhorando as condições de vida individual e do coletivo, já que a ciência faz parte da cultura dos tempos atuais. A Educação Científica, na opinião de pesquisadores, é urgente por ser essencial para o desenvolvimento das pessoas e dos povos, tornando-os capazes de tomarem decisões que influenciem no plano individual ou coletivo, em questões de ciências, de tecnologias e para o conhecimento do mundo natural (FOUREZ, obra citada).

Um dos caminhos para tentar-se reverter esta crise no ensino de ciências é adotar uma postura voltada à Abordagem Cognitivista, que tem como seu principal representante, Jean Piaget que enfatiza a capacidade do aluno de integrar e processar informações. $\mathrm{O}$ conjunto do conhecimento dá-se por meio da interação entre homem e mundo e não existe conhecimento pronto e acabado, visto que o homem se encontra sempre em processo contínuo e sucessivo de reequilibração. O conhecimento é considerado como uma construção contínua e a passagem de um estado de desenvolvimento para o seguinte é sempre caracterizado pela formação de novas estruturas que não existiam anteriormente no indivíduo. (MIZUKAMI, obra citada).

Construir na teoria piagentiana implica tornar as estruturas do comportamento, motoras, verbais ou mentais, mais complexas, ou seja, realizar novas combinações. Ao se provocar situação de desequilíbrio, adequada ao nível de desenvolvimento em que se encontra o aluno, é possível a construção progressiva do conhecimento. O sistema escolar deve criar condições para que não haja coação sobre os alunos e que possibilite a autonomia e a prática de atividades em grupo com aspecto integrador, visto que cada membro possui suas realidades. Ao professor cabe criar situações, fazer desafios e propiciar condições que possam provocar desequilíbrios, assumindo um papel de investigador, pesquisador e orientador e levando o aluno a trabalhar o mais independentemente possível (MIZUKAMI, obra citada).

A RESOLUÇÃO CNE/CP n ${ }^{\circ}$ 1, de 18 de fevereiro de 2002, prevê que o ensino básico deva visar: à aprendizagem do aluno; ao acolhimento e ao trato da diversidade; ao exercício de atividades de enriquecimento cultural; ao aprimoramento em práticas investigativas; à elaboração e à execução de projetos de desenvolvimento dos conteúdos curriculares; ao uso de tecnologias da informação e da comunicação; metodologias, estratégias e materiais de apoio inovadores; ao desenvolvimento de hábitos de colaboração e de trabalho em equipe; entre outros. A presença da prática profissional na formação do professor, que não prescinde da observação e ação diretas, poderá ser enriquecida com 
tecnologias da informação, incluídos o computador e o vídeo, narrativas orais e escritas de professores, produções de alunos, situações simuladoras e estudo de casos (BRASIL. Resolução CNE/CP 1/2002).

As inovações didáticas juntamente com as concepções construtivistas não são suficientes para estruturar um currículo se os professores não souberem aplicá-lo. Este fato ocorre porque os professores de Ciências na sua formação desenvolvem uma imagem espontânea de ensino e o consideram como algo simples para o qual basta ter apenas o conhecimento da matéria, fato esse que deriva de uma formação inadequada e por não possuírem consciência de suas práticas que são embasadas apenas na transmissão pura do conhecimento, como já comentado anteriormente.

O desenvolvimento de trabalhos coletivos, tanto na formação inicial dos professores, quanto na formação continuada e também no trabalho do dia a dia nas escolas, pode contribuir para a mudança dessas concepções que foram herdas de sua formação desde os primeiros anos escolares. O desenvolvimento de trabalhos coletivos embasados em uma pesquisa dirigida, de reflexão sobre suas práticas, sobre a de seus companheiros de profissão e na troca de experiências, pode mudar essas suas concepções iniciais. Grupo de professores discutindo suas dificuldades e buscando nas pesquisas existentes respostas que os auxiliem em suas atividades docentes pode levá-los a encontrar respostas para suas questões e transformar sua prática.

Em síntese, a proposta seria a de elaboração de atividades problemáticas que levassem em consideração as destrezas, a visão de mundo e o cotidiano dos alunos e pudessem propiciar-lhes um interesse prévio pela disciplina de Ciências e contribuir para o desenvolvimento de habilidades e para a construção de conhecimento, sendo que, neste intento, defende-se a utilização dos artefatos computacionais como uma ferramenta pedagógica. 


\section{Capítulo II - Novas tecnologias no ensino de Ciências: Artefatos Computacionais, Professor e Aluno}

A criança terá direito à liberdade de expressão; este direito inclui a liberdade de procurar, receber e partilhar informação de todos os tipos, independentemente de fronteiras, seja oral, escrita ou impressa, na forma de arte ou através de qualquer outro meio de escolha da criança. (Convenção da ONU sobre os Direitos da Criança e do Adolescente, 1989).

Nessa perspectiva o uso pedagógico dos Artefatos Computacionais pode auxiliar a garantia desses direitos, visto que facilita a liberdade de expressão, a busca e o compartilhamento de informações. Quando nos referimos a "Artefatos Computacionais", estamos nos reportando a equipamentos como laptops, ipads, palmtops, tables, celulares e inúmeros outros recursos que possuem funções semelhantes e podem ser utilizados como instrumentos pedagógicos que facilitem e contribuam a aprendizagem. Esses equipamentos estão inseridos na atual sociedade e podem ser vistos como um recurso didático utilizado no processo de ensino e da aprendizagem e, estando a serviço da educação, podem transpor os muros das escolas sendo o seu alcance inimaginável.

Essa mudança no fazer pedagógico com a utilização desses artefatos computacionais requer do docente uma ação reflexiva sobre a sua prática, que se por ventura não esteve presente na sua formação inicial, hoje com certeza, de uma forma ou de outra, está presente na escola onde trabalha e no seu cotidiano.

Conceitualmente a palavra "artefato" provém do latim e significa, "arte factu": feito com arte. O Dicionário de Aurélio Buarque de Holanda, define artefato como sendo "qualquer objeto produzido industrialmente". Um artefato é o resultado tangível de um processo de produção. Um ou mais processos podem produzir ou alterar um artefato. Da mesma forma, um determinado processo pode necessitar de um ou mais artefatos para poder ser executado.

Desta forma, Artefato Cultural pode ser definido como sendo um objeto feito pela mão do homem que fornece informações sobre a cultura do seu criador e usuários, sendo que a classificação sobre quando, como e o porquê ele é usado pode mudar ao longo do tempo dependendo de novas descobertas. Nesse sentido, o computador que é um instrumento que podemos considerar como sendo criado pelo homem e que se desenvolve a cada dia na 
sociedade moderna e que também possui caracteristicas da natureza humana quando é usado individualmente ou coletivamente, pode ser considerado como um Artefato Cultural.

\subsection{Mediação: Professor - Artefatos computacionais - Aprendizagem}

Para a nossa pesquisa, nos limitamos às concepções de mediação propostas por Vygotsky que, apesar de ter vivido em uma época em que não se imaginava a existência de computadores, produziu uma obra que pode ser referência teórica para classificar os Artefatos Computacionais como instrumentos culturais com signos. Para ele, a relação do sujeito com o conhecimento não é uma relação direta, mas sim mediada pelo outro, por instrumentos e por signos, ou seja, agimos no mundo físico fundamentalmente de forma indireta ou mediada. Esse conceito é assim explicado:

Mediação, em termos genéricos, é o processo de Intervenção de um elemento intermediário numa relação; a relação deixa, então de ser direta e passa a ser mediada por esse elemento (OLIVEIRA, 2010, p. 28).

Para Vygotsky, é por meio do trabalho que o homem transforma a natureza, cria a cultura e a história humana; desenvolve atividades coletivas, estabelece relações sociais, cria as invenções e instrumentos. Segundo o autor, o homem não tem acesso direto aos objetos, mas um acesso mediado por outros sujeitos, por instrumentos elaborados para a realização da atividade humana e por signos, considerados instrumentos psicológicos que têm a função de auxiliar o homem nas suas atividades psíquicas.

O trabalho humano caracteriza-se pela atividade produtiva e comunicativa, sendo que com os animais, essas atividades são distintas e não se confundem. Para Vygotsky, habilidade humana de construir instrumentos e produzir signos marca o seu comportamento, bem como a sua cultura, o que foi possível graças à linguagem. Os chimpanzés, por exemplo, segundo o autor, não criam instrumentos para serem úteis a eles no dia a dia, por não possuírem linguagem e terem um poder imaginativo limitado.

O homem produz seus instrumentos para a realização de tarefas específicas e é capaz de conservá-los para uso posterior, de preservar e transmitir sua função aos membros de seu grupo, de aperfeiçoar antigos instrumentos e de criar novos. Com o auxílio dos signos, o homem pode controlar, voluntariamente, sua atividade psicológica e ampliar sua capacidade de atenção, memória e acúmulo de informações. 
Os instrumentos são elementos externos ao indivíduo e têm como função provocar mudanças nos objetos. Estão intercalados entre o trabalhador e o objeto do seu trabalho, sendo produzidos especificamente para uma determinada finalidade e possibilitando a transformação da natureza. Desta forma, os instrumentos têm características peculiares para cumprir as funções para o qual foram criados; características estas que se desenvolvem durante a história do trabalho coletivo, ou seja, os instrumentos são objetos sociais e mediadores das relações entre o sujeito e o mundo.

Os signos, por sua vez, são direcionados para o próprio sujeito e auxiliam nos processos psicológicos e não nas ações concretas com os instrumentos. São determinados símbolos, sinais, sons e outras marcações que são utilizados como instrumentos que auxiliam no desempenho de atividades psicológicas, melhorando as possibilidades de armazenamento de informações. A memória mediada por signos é mais eficiente do que uma não mediada. Durante a história da humanidade, verifica-se que os signos são compartilhados pelos membros dos grupos sociais, permitindo a comunicação, a interação e a organização dos seus integrantes, sendo a linguagem o sistema simbólico básico de todos os grupos humanos (OLIVEIRA, obra citada).

Vygotsky distinguiu instrumento de signo devido às suas funções mediadoras. Os instrumentos são externamente orientados pelo sujeito e tem a função de controle da natureza causando transformação nos objetos e, por conseguinte, no próprio sujeito que o opera. Já os signos são internamente orientados e têm a função de comunicação, controle e domínio do comportamento do próprio indivíduo.

Coadunando-se com essas concepções de Vygotsky, podemos considerar os Artefatos Computacionais como sendo exemplos de instrumentos com signos. Instrumento no sentido de ser uma máquina, que manipulada pelo ser humano, produz signos por meio de seus recursos computacionais os quais categorizamos como veremos adiante, em: Multimídia Computacional, modelagem Computacional e Internet.

Os Artefatos Computacionais são produções humanas que vêm se aprimorando a todo o momento, e dessa forma, podem ser considerados como produção cultural que se caracteriza por possuir componentes materiais e simbólicos. Sua criação é o resultado do esforço do homem para interferir na realidade em que vive. São objetos físicos e os seus recursos computacionais têm uma dimensão simbólica, visto que seu funcionamento depende de símbolos e seus programas são construídos a partir de uma linguagem binária. Para acioná- 
los temos de seguir instruções escritas na tela, movimentar o mouse entre diferentes ícones, usar o teclado com letras e números para redigir instruções e navegar na internet, interagindo com pessoas de qualquer parte do mundo.

O primeiro registro que se tem de um artefato construído para auxiliar o homem a resolver cálculos, que pode ser considerado como sendo o primeiro computador, data de aproximadamente sete mil anos atrás. Este artefato era o ábaco que foi a primeira calculadora da história a ser utilizada por povos antigos para a realização de cálculos do dia-a-dia utilizando um sistema simples, mas muito eficiente na resolução de problemas matemáticos. No decorrer da história, a humanidade foi sempre construindo e aprimorando instrumentos para facilitar a sua vida no cotidiano, e atualmente, temos o computador da forma que o conhecemos e que continua constantemente sendo aprimorado.

Segundo FREITAS (2009), os Artefatos Computacionais e seus recursos são, simultaneamente, instrumento material e simbólico e, aliado ao fato de ser construído pelo homem, pode ser uma Ferramenta Cultural de mediação da ação humana para a aprendizagem, facilitando a construção do conhecimento na relação com o outro, sendo que a relação do sujeito com o conhecimento não é direta mas mediada por esse artefato, que tem o sentido de efetuar mudança no objeto e, por conseguinte, no sujeito que o opera.

O Quadro 1, apresentado a seguir, demonstra este movimento de mediação realizado pelo computador entre o professor e a aprendizagem, o qual também pode ser realizado por outros recursos didáticos.

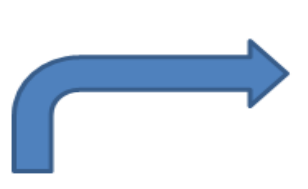

\section{OUTROS RECURSOS} DIDÁTICOS

PROFESSOR

APRENDIZAGEM

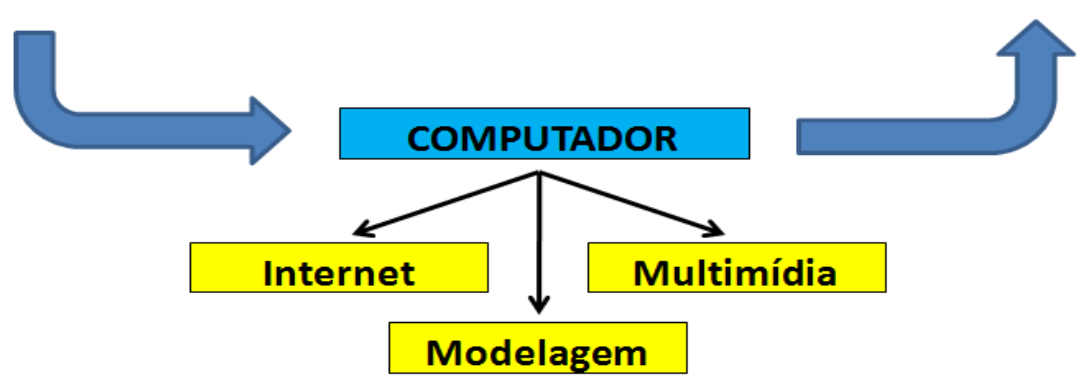

(Quadro 1 - Computador como instrumento para mediação do professor com a aprendizagem) 
Os Artefatos Computacionais e seus recursos propiciam uma interação com as informações, com o conhecimento e com outras pessoas o que reporta a uma concepção de aprendizagem em uma perspectiva histórico-cultural que se realiza por meio da interação, ou seja, propõe uma nova relação entre professor e aluno baseada no diálogo, nas ações em conjunto, na aprendizagem coletiva na qual o professor é um orientador.

Atualmente, os Artefatos Computacionais, de uma forma geral, são parte integrante em nossa vida de uma forma nunca vista anteriormente, basta nos reportamos há alguns anos atrás e comparar. Seja em casa, na escola, na faculdade, na empresa, ou em qualquer outro lugar, eles estão sempre presentes entre nós. Ao contrário do que parece, a computação não surgiu nos últimos anos ou décadas, mas sim há mais de sete mil anos como já citamos, desde o ábaco, passando pela máquina de pascal, lógica de Boole, computadores mainframes, Steve Jobs, Bill Gates, entre vários outros. Nesse contexto, a introdução de Artefatos Computacionais na aprendizagem é um desafio principalmente para as escolas que estejam centradas no paradigma da transmissão de conhecimentos.

\subsection{Artefatos Computacionais: sua importância para o ensino-aprendizagem e as necessidades para a formação de professores}

Seremos reconhecidos socialmente como sujeitos do conhecimento e
verdadeiros atores sociais quando começarmos a reconhecer-nos uns aos
outros como pessoas competentes, pares iguais que podem aprender uns com
os outros. Diante de outro professor, seja ele do pré-escolar ou da
universidade, nada tenho a mostrar ou a provar - mas posso aprender com
ele como realizar melhor nosso ofício comum. (TARDIF, 2002, p. 244).

Essa citação de Tardif refere-se à profissionalização do professor, que não deve contemplar divisões que gerem sensações de poder ou prestígio, visto que o único objetivo de todos os professores, que atuam em qualquer faixa etária, é o de educar. Os Artefatos Computacionais por sua vez, estão presentes em toda a sociedade e, por conseguinte também, na escola que é parte integrante daquela, sendo que a tecnologia pode auxiliar os profissionais da educação em qualquer etapa de atuação. Uma das razões para se obter resultados qualificados e duradouros pode estar em transformar a escola em um espaço prazeroso de construção de conhecimentos e os recursos telemáticos podem contribuir nesse sentido. $\mathrm{O}$ potencial tecnológico desenvolve-se de forma desenfreada e precisa ser viabilizado na perspectiva de enriquecer e direcionar a formação dos cidadãos que começa deste a mais tenra idade. 
Com a visão de que a tecnologia possa estar ou não a serviço do homem, os professores podem ser críticos para contemplar em sua prática pedagógica o uso da informática, oferecendo esse recurso inovador aos alunos. Os professores e os alunos podem utilizar as tecnologias da informação para estimular o acesso à informação e à pesquisa individual e coletiva, favorecendo o processo para aumentar a interação entre eles. Com o uso de Artefatos Computacionais, ao longo do tempo, o aluno pode deixar de ser receptor de informações para ser responsável pela construção do seu conhecimento, pois por meio da Internet é possível buscar e selecionar as informações significativas segundo o seu interesse. Cabe ao professor construir ambientes de aprendizagem desafiadores e direcionar para que a tecnologia ajude a promover o desenvolvimento cognitivo no aluno e o leve à construção do conhecimento (MORAN et al, 2000).

Desta forma, a utilização dessa tecnologia no contexto educacional pode reformular as relações entre professores e alunos em um espaço diversificado de construção de conhecimento, expandindo-o para além da sala de aula sem fronteiras que os impeçam de compartilhar ideais, experiências e opiniões com qualquer pessoa no mundo, fazendo surgir condições para que os alunos possam adquirir um conhecimento antes não propiciado pelas limitações da tecnologia do lápis, do papel, da lousa e do livro didático.

Muitas escolas investem na aquisição e utilizam computadores operados por técnicos sem a formação pedagógica necessária, apenas como marketing para atrair maior número de alunos, com o slogan de que "oferecem qualidade na educação”, por possuírem laboratórios de informática. Os professores dessas escolas, por sua vez, resistem à adoção de um trabalho pedagógico mediado pelo uso de recursos didáticos da telemática, principalmente por ignorarem a utilização dos equipamentos, sendo que não há melhoria real no processo educativo e essas escolas estão fazendo apenas uma propaganda enganosa.

A esse respeito, Freitas (2009) aponta que os professores mostram-se tímidos e inseguros, não conseguindo incluir o uso dessas tecnologias no cotidiano de suas aulas, colocando para fora da sala de aula o computador e seus recursos, sendo vistos apenas como um potencial tecnológico, que não é ser incluído no processo de aprendizagem como um elemento revolucionário das práticas pedagógicas.

Nesse sentido, não basta equipar as escolas com salas de informática e propiciar aos professores cursos de treinamento do uso desses equipamentos, sem um estudo mais profundo da utilização desses instrumentos e seus recursos, a fim de adequá-los às 
necessidades e aos objetivos educativos. O computador não pode ser visto como um intruso, como algo necessário para manter a escola modernizada visando marketing, sem se ter consciência da sua real necessidade de utilização pedagógica, sendo que a organização escolar deve ser repensada para a inclusão dessa tecnologia e para a mudança na grade curricular.

Vivemos no mundo da telemática, e ela pode propiciar a alunos e professores a oportunidade de entrar em contato com as mais novas e recentes informações, pesquisas e produções científicas do mundo todo e de todas as áreas, inclusive o acesso a bibliotecas, museus, pinacotecas e outros. Ela propicia a integração de movimento, luz, som, imagem, filme, vídeo e faz surgir novas formas de construir o conhecimento. As possibilidades de troca de informações são intensificadas, já que professores e alunos são colocados em contato fora dos horários de aulas e o processo de aprendizagem a distância pode ocorrer. Os alunos apossam-se das informações outrora ensinadas pelo professor em aulas expositivas e se tornam, então, mediadores (MORAN et al, 2000).

A esse respeito, vemos que o mundo globalizado da atualidade necessita de respostas rápidas e as pessoas envolvidas nesse processo não apreciam a demora. $\mathrm{O}$ acesso à Internet possibilita a busca das informações desejadas e representa uma nova ferramenta para o aprendizado, sendo que se faz necessária a seleção dos dados fornecidos, devido ao acúmulo de informações. Muitos dados e informações não significam necessariamente maior e melhor qualidade de conhecimento. O desafio para os educadores é o de conhecer e selecionar as informações verdadeiramente importantes entre tantas e torná-las significativas para o aluno.

Hoje em dia, os três "w" são intuitivamente ligados ao "ponto", o que faz as pessoas reconhecerem essa sequência como algum sítio da Internet, mesmo que nenhuma outra referência ao meio seja fornecida. Por isso, a presença do léxico da Internet em quase todo meio de comunicação oral e escrito pode ser considerado uma forte evidência de sua disseminação pelo mundo inteiro. (GIORDAN, 2008, p.239).

Os Artefatos Computacionais permitem pesquisar, simular situações, testar conhecimentos específicos, descobrir novos conceitos, lugares, ideias, produzir novos textos, avaliações e experiências. O professor pode, por meio de uma metodologia inovadora, criar possibilidades de encontros presenciais e virtuais que levem o aluno a acessar as informações disponíveis em todo o universo da Internet, motivando-o e sensibilizando-o sobre o valor da atividade que vai ser realizada e de sua importância nesse processo. A partir daí, o aluno participa e torna-se responsável pela qualidade e escolha das informações coletadas, sendo o professor o mediador desse processo de aprendizagem (MORAN et al, 2000). 
Como usuário da rede de informações, o aluno poderá ser iniciado como pesquisador e investigador para resolver problemas concretos que ocorrem no cotidiano de sua vida. A aprendizagem precisa ser significativa, desafiadora, problematizadora e instigante, a ponto de mobilizar o aluno e o grupo a buscarem soluções possíveis para serem discutidas. $\mathrm{O}$ aluno precisa ser instigado a buscar o conhecimento, a ter prazer em conhecer, a aprender a pensar, a elaborar as informações para que possam ser aplicadas à realidade em que está vivendo.

É observável que a Internet possibilita que os adolescentes escrevam mais e que também leiam mais, passando horas diante do computador, criando uma escrita teclada criativa, com códigos apropriados que facilitam e agilizam esse tipo de comunicação. Em contra partida, o que se vê entre os professores desses adolescentes é um desconhecimento desse novo cotexto, acompanhado de preconceitos linguísticos, sociais e culturais para com as relações, as práticas de escrita e as leituras que essa interação pela Internet propicia. Freitas, na obra já citada, define letramento digital como as práticas de leitura-escrita possibilitadas pelo computador e Internet:

[...] compreender que a introdução de novas práticas sociais de leitura-escrita propiciadas pelo computador e Internet permite a definição de letramento digital como o 'estado ou condição que adquirem os que se apropriam da nova tecnologia digital e exercem práticas de leitura e de escrita na tela, diferente do estado ou condição - do letramento - dos que exercem práticas de leitura e de escrita no papel (FREITAS, 2009, p. 59).

A Fundação Getúlio Vargas (FGV) divulgou dados estatísticos do Instituto Gallup e do Censo de 2010, no Mapa da Inclusão Digital (2012), indicando que 51,2\% da população pesquisada no Brasil têm acesso a celular, telefone fixo, computador e internet, em casa, enquanto a média global é de $49,1 \%$. Os dados ainda apontam que em comunidades carentes como, por exemplo, as favelas do Rio de Janeiro, entre elas as favela do Alemão, Jacarezinho, Maré e Rocinha, o percentual ultrapassa a média Global e a maioria a média do Brasil, variando entre $50,8 \%$ a $57,5 \%$.

Esses dados mostram que existe ainda uma parte da população que se encontra em estado de exclusão digital, mas o que se vê é que mesmo em comunidades carentes, alunos que não possuem computador em casa podem ter contato com essas máquinas em casa de amigos, lan house e em outros lugares. Dessa forma, o computador com seus recursos, principalmente o da Internet, possibilita que os alunos relacionem-se virtualmente, escrevendo mais, utilizando uma linguagem própria que facilita e agiliza a digitação. Essa linguagem, 
segundo Freitas (obra citada), é desconhecida e carregada de preconceitos por parte dos professores, fato que demonstra a necessidade de estudos sobre a relação do professor com a prática da leitura e da escrita digitais e sobre os processos de aprendizagem que se adéquam às inovações tecnológicas. Assim, os cursos de formação inicial e continuada devem contemplar essas dificuldades, apontando saídas reais que contribuam com a integração da aprendizagem com o computador e seus recursos. (FREITAS, obra citada).

Outro fator a ser considerado é que a presença de Artefatos Computacionais nas escolas, como acontece em toda transição de paradigma, pode gerar certo desconforto, principalmente em professores, devido à complexidade do seu uso como meio pedagógico que requer dos professores uma formação específica para a sua utilização. Há professores que se preocupam com a aprendizagem na perspectiva da construção do conhecimento, estimulando a pesquisa, a investigação, a imaginação e a criatividade. Outros, por sua vez, resistem ao novo e outros tantos já utilizam o computador, mas ainda centrados na transmissão de conhecimentos. Pode acontecer também de algumas dessas mudanças não serem bem aceitas por alunos, por estarem acostumados a serem apenas ouvintes, recebendo tudo pronto do professor e também por estarem acostumados a utilizarem o computador para outros fins.

A rigidez da estrutura curricular da escola, sua preocupação com "o que ensinar” e não com "o como ensinar" e a metodologia tradicionalista de ensino estão sendo postas em descrédito, devido à velocidade com que as informações são produzidas e ao impacto que as novas tecnologias ocasionam sobre as relações de trabalho, convívio social, aprendizagem etc, o que determina novas formas de aprender, fazendo-se necessário repensar o papel do professor, sua formação, capacitação e, sobretudo, a necessidade de mudanças da sua prática em sala de aula. Freitas esclarece que:

O computador e a Internet ainda estão colocados do lado de fora da sala de aula. São vistos apenas como mais um recurso tecnológico à sua disposição (professores), mas não reconhecem neles as suas reais potencialidades para serem incluídos como instrumento de aprendizagem que revolucionem a prática pedagógica. (FREITAS, 2009, p.70.)

Neste sentido, também Tardif (obra citada) propõe que se deva levar em consideração na formação de professores o fato de que eles possuem competência para atuar na sua própria formação; que o trabalho do professor exige conhecimentos específicos de sua profissão; e que as disciplinas devem ter relação entre si, com longa duração e que tragam 
impacto sobre o aluno, além de possuírem uma lógica profissional baseada na análise e na reflexão das práticas docentes. Para isso, tanto o professor formador quanto o que está sendo formado têm de sentir a necessidade de adequação dos cursos de formação às realidades tecnológicas em que vivem na contemporaneidade, ou seja, o profissional docente formador e o formando têm de sentir a necessidade da inclusão das tecnologias em sua prática docente e a importância que elas têm para a interação com a sociedade. A inclusão dos recursos computacionais nas escolas e sua utilização pedagógica podem ser facilitadas se houver na formação inicial e continuada de professores a preocupação com essa questão.

O atual contexto da sociedade da informação direciona para a necessidade de que se pense em cursos de formação de professores que aliem o uso das Tecnologias da Informação e da Comunicação (TIC) à teoria e às práticas educativas, uma vez que trabalhar com as TIC exige do professor uma nova postura na organização do currículo, nas metodologias implantadas em sala de aula e na condução das aprendizagens. O que se observa, entretanto, é a prioridade que está sendo dada para a introdução nas escolas de computadores e da Internet, como se isso, por si só, fosse resolver os problemas de ensino, não se dando a devida importância para a formação de professores capazes de assumirem o papel de orientadores e organizadores dos ambientes de aprendizagens em ambientes tecnológicos sejam eles presenciais ou a distância, com atividades práticas e reflexivas, sem as quais não é possível operar grandes mudanças nas práticas pedagógicas dos docentes (PONTE, 2000).

As novas condições de produção de conhecimentos levam a novos tipos de sociedade provenientes das relações entre as pessoas e os recursos tecnológicos, sendo que os impactos que as novas tecnologias trazem são percebidos na velocidade com a qual as informações são produzidas e transmitidas nas relações sociais. Esse fato abala a estrutura curricular das escolas onde a preocupação está nos produtos e não nos processos de produção do saber. A introdução paulatina das tecnologias na escola pode a vir a determinar novas formas de aprendizagem e, consequentemente, devem ser revistos o papel do professor, sua formação e capacitação. (FREITAS, obra citada).

Desta forma, as possibilidades educativas propiciadas pelos Artefatos Computacionais podem levar a se pensar em novos caminhos para a formação de professores que se adaptem aos novos ambientes digitais, à informática nas escolas, ao letramento digital e às mudanças nas práticas docentes. Também é necessário pensar em uma formação que 
desenvolva no professor a compreensão do processo de ensino e o desenvolvimento dos alunos frente às novas tecnologias, fazendo-os entenderem os fatores sociais, econômicos e políticos que os norteiam.

A utilização de artefatos computacionais na formação de professores não tem como objetivo apenas proporcionar o domínio dos recursos, mas principalmente desenvolver no professor uma prática pedagógica reflexiva, uma vez que apenas o uso dessas tecnologias não garante uma melhor qualidade do ensino. O que podemos concluir é que a formação de professores voltada para a utilização de artefatos computacionais na Educação pode contribuir para o aprimoramento da prática educativa se houver a compreensão das possibilidades e dos limites que esse instrumento tecnológico tem no papel educativo da escola, não só focado em como utilizá-los nas práticas educativas, mas também por que fazê-lo. A formação de professores capazes de utilizar artefatos computacionais como uma ferramenta nas práticas educativas exige uma capacitação técnica e uma prática reflexiva (VALENTE, 1997).

Além disso, os artefatos computacionais podem ser uma importante ferramenta na escola se houver uma formação adequada dos professores para o seu uso, uma formação que associe o domínio dos recursos tecnológicos a uma análise crítica das suas implicações na Educação e na Cultura, de modo a constituir professores que: procurem resolver os dilemas envolvidos em suas práticas de sala de aula; estejam alertas para as questões dos valores que conduzem sua prática pedagógica; estejam atentos para o contexto institucional e cultural no qual ensinam; tomem parte do desenvolvimento curricular e se envolvam efetivamente para a sua mudança; assumam a responsabilidade por seu desenvolvimento profissional; e procurem trabalhar em grupo, pois é nesse espaço que vão se fortalecer para desenvolver o trabalho docente (GERALDI, 1998).

Para finalizar, esclarecemos que a utilização de artefatos computacionais nas práticas educativas exige investimento no desenvolvimento profissional do professor, capacitando-o para entender por que e como integrar essa tecnologia à sua prática educativa, atendendo aos objetivos pedagógicos e às necessidades de seus alunos, sendo dessa forma, essencial a reflexão da sua própria prática. A participação do professor em cursos, congressos, estudos específicos, pesquisas na internet, a leitura de livros e de trabalhos acadêmicos também podem favorecer o processo de reflexão da prática pedagógica, bem como a capacitação técnica dos professores. 


\subsection{Modos de utilização dos Artefatos Computacionais}

O trabalho de monografia citado na Introdução dessa dissertação foi apresentado no XI Encontro de Pesquisa em Ensino de Física, em Curitiba, 2008 sob a forma de um artigo intitulado "Motivação do aluno e o uso do computador em aulas de Física". Nesse encontro, houve três outros trabalhos que lá foram apresentados que se reportavam ao assunto de Tecnologias Computacionais para o ensino de Física.

O primeiro, intitulado "Tecnologias Computacionais Aplicadas à Aprendizagem Cooperativa em Física" (MARTINS et al, 2008) tinha como objetivo a investigação da aplicação de uma metodologia de ensino que estimulava a aprendizagem cooperativa por meio de tecnologia cognitivo-computacional, propondo em um ambiente virtual de aprendizagem, a criação de situações de aprendizagem, estratégias e procedimentos de ensino com o intuito de oferecer oportunidades para os estudantes construírem conhecimento de maneira reflexiva, criativa e cooperativa. Foram utilizadas de forma integrada tecnologias computacionais como: softwares de simulação e de editoração de mapas conceituais, fóruns, chats, bases, wiki e internet, com o objetivo de envolver os estudantes em atividades interativas e desafiadoras que exigissem competências cognitivas de aprender com tecnologia e estimular o desenvolvimento da metacognição. Nesse estudo, foram investigados processos de ensino e aprendizagem de conceitos básicos de mecânica, direcionados a alunos da primeira série do Ensino Médio; aplicando-se uma abordagem do tema diferenciada do ensino tradicional. A conclusão foi que as tecnologias de informação e comunicação podem contribuir para a criação de metodologias de ensino inovadoras que estimulem a construção do conhecimento, a ação, a reflexão, a contextualização, a cooperação e a competência metacognitiva. No entanto, foi observado que essas tecnologias devem estar integradas em um sistema e não em separado.

O segundo, intitulado “A Utilização de Recursos Multimídias em Aulas de Física a partir do referencial teórico de Vygotsky" (MONTEIRO, 2008) tratava da utilização dos recursos de multimídia e de softwares, voltados para a educação, por professores que não conseguem ultrapassar os procedimentos tradicionais de transmissão de informação, os quais utilizam a tela do computador apenas para a simples transferência de páginas dos livros didáticos, por desconhecimento do funcionamento de tais equipamentos para desenvolver e dirigir atividades de ensino de uma maneira didático-pedagógica. Foi investigada a utilização de simulações mediadas pelo computador no contexto de uma aula de Física, segundo uma 
abordagem baseada na teoria sócio-histórica de Vygotsky, cujo objetivo foi analisar o papel do professor no processo de ensino que utiliza o recurso multimídia. Os resultados mostraram a importância do papel do professor e das interações sociais por ele desencadeadas no entendimento e na motivação dos alunos. A utilização de recursos multimídias em sala de aula mostrou-se de suma importância, pois é uma ferramenta poderosa à disposição do professor para auxiliar o processo de ensino e de aprendizagem, mas é fundamental que o professor disponha de uma competência pedagógica capaz de explorar todas as possibilidades que esses recursos podem oferecer.

O terceiro trabalho, intitulado "Uma Simulação de Computador como Ferramenta de Enculturação Científica"” (SILVA et al, 2008), propõe uma atividade de simulação no computador, denominada "O Problema da Pressão", com um grupo de dez crianças entre 9 e 11 anos de idade, de um bairro da Zona Sul da cidade de São Paulo. Por meio do registro daquela aula, pretendeu-se estudar o processo de Enculturação Científica naqueles alunos, buscando a ocorrência de indícios ou não dos indicadores da Enculturação Científica, normalmente observada numa aula convencional de Conhecimento Físico. As crianças não alcançaram o objetivo da atividade que era o de perceber a relação entre a coluna e o jato de água e também foram pouco observados os aspectos de Enculturação Científica estudados, entretanto notou-se uma série de erros do professor na condução de uma aula de conhecimento físico. Para chegar-se a uma conclusão se a simulação apresenta problemas de compreensão ou se não é adequada para aquele tipo de aula, o autor apontou que serão necessários outros testes em que não ocorram erros tão graves do professor, mas ficou a suspeita de que os alunos têm uma dificuldade maior em compreender o problema virtual do que o real, sendo necessários também novos testes para comprovar-se essa afirmação.

O XIII Encontro de Pesquisa em Ensino de Física, em Foz do Iguaçu, em 2011, foi o último ocorrido e dos trabalhos nele apresentados destacamos o artigo intitulado "Estudo Exploratório Sobre as Concepções dos Professores de Física Acerca dos Objetos Educacionais Digitais" (ARANTES et al, 2011). Esse trabalho teve por objetivo revelar as atuais concepções dos professores de Física acerca dos objetos educacionais digitais, dentre os quais foram incluídos simulações, animações e softwares educacionais. Os resultados indicaram que os objetos educacionais digitais ainda não faziam parte do cotidiano escolar dos profissionais

\footnotetext{
${ }^{2}$ Na perspectiva da Enculturação Científica esperam-se identificar três aspectos básicos: o entendimento das relações existentes entre ciência e sociedade, a compreensão da natureza da ciência e dos fatores éticos e políticos que circundam sua prática e a compreensão básica de termos e conceitos científicos fundamentais (Carvalho, 2008).
} 
que estavam atuando no ensino de Física, pela simples falta de conhecimento de fontes dessa ferramenta e, consequentemente, do conhecimento sobre como utilizá-los em aula. No entanto, constatou-se que ao tomar conhecimento dos objetos educacionais e de sua eficiência todos se tornaram bastante motivados para empregá-los em sua proposta pedagógica.

Outro trabalho que apontamos é a dissertação de TÓFOLI (2003), na qual o autor faz uma análise dos trabalhos apresentados nos Simpósios Nacionais de Ensino de Física (SNEF - 1993 a 2003), Revista Brasileira de Ensino de Física (RBEF - 1993 a 2002) e Caderno Catarinense de Ensino de Física (RBEF -1993 a 2002). Nesses trabalhos, o pesquisador identificou as diversas possibilidades que as tecnologias computacionais podem oferecer para contribuir com o ensino de Física, percebendo que a preocupação nos raros trabalhos ali apresentados estava na produção e utilização de softwares simuladores, e os professores, apesar de perceberem a importância e a potencialidade pedagógica dos Artefatos Computacionais, ainda não o utilizavam de forma expressiva em suas práticas docentes, analisando que a causa, estaria nas relações que os professores estabelecem possuem com essa tecnologia.

Dessa forma, o que se constatou pela análise desses trabalhos, incluindo a nossa monografia citada na Introdução, é a confirmação de nossa hipótese inicial que vem ao encontro do que se defende até agora quanto à utilização de Artefatos Computacionais e de seus diversos recursos para o ensino. Esses trabalhos, de uma forma geral, concluem que as TIC podem contribuir com metodologias inovadoras de construção do conhecimento e também podem ser de suma importância na sala de aula, visto que sua utilização pedagógica indica que elas contribuem com o trabalho docente e se manipuladas de forma eficiente, ainda se tornam motivadores para o ensino e para a aprendizagem. Para tanto, seria necessário que a prática docente não se limitasse apenas a formar cidadãos tecnologicamente alfabetizados, com sensibilidade crítica acerca do desenvolvimento da ciência e da tecnologia, mas que os professores também possuam competências pedagógicas capazes de explorar de forma abrangente as possibilidades que esses recursos podem oferecer.

As diversas possibilidades da utilização dos Artefatos Computacionais podem permitir uma diversificação de estratégias no ensino, visto que esse instrumento pode ser um importante meio pedagógico a ser utilizado, pela exploração dos seus diversos recursos como, por exemplo: editor de texto; registro de documentos; elaboração de trabalhos; construção de artigos e de textos; confecções de tabelas, gráficos e simuladores; armazenamento de dados; exibição e apresentação de filmes e trabalhos; além do que, se conectado à internet, seu 
usuário pode ainda interagir com a rede mundial de computadores e compartilhar todo o conhecimento que produzir.

Os celulares multifuncionais, por exemplo, carregam textos, fotos, músicas, dicionários, catálogo, mapas, internet etc, e seus usuários têm acesso a informações em tempo real e podem pesquisar qualquer assunto on-line. $\mathrm{O}$ conhecimento encontra-se condensado em um pequeno apetrecho portátil com acesso rápido por meio de um simples toque. Este é um exemplo de um Artefato Computacional que faz parte da produção da cultura humana e possui condições de acesso e utilização nas relações de ensino.

Fiolhais e Trindade (2003) indicam como sendo cinco as principais modalidades do uso de computadores no ensino de Física: aquisição de dados por computador; modelagem e simulação; materiais multimídia; realidade virtual; e busca de informações na internet.

1. Aquisição de dados por computador refere-se ao uso do computador no laboratório escolar, com a finalidade de coletar dados de experimentos através da utilização de sofwares e sensores desenvolvidos para esse fim, com os quais os alunos podem medir e controlar variáveis, permitindo a realização de medições de grandezas físicas em tempo real;

2. Modelagem e simulação referem-se à utilização de modelos de equações e a simulação de imediato de um dado problema físico cujas ações básicas dos alunos consistem em alterar valores de variáveis e observar as alterações que ocorrem nos resultados, permitindo ao aluno construir modelos do mundo físico, além de demonstrá-los graficamente;

3. Materiais multimídia referem-se ao fato de que o computador pode incluir uma variedade de elementos como: textos, sons, imagens, simulações e vídeos, tendo como características essenciais a interatividade e a flexibilidade de escolha do caminho a seguir. A multimídia pode funcionar "on-line" ou "off-line", dependendo do local onde se procura a informação;

4. Realidade Virtual refere-se à possibilidade de interação entre o homem, a máquina e o ambiente virtual em um cenário construído por modelos tridimensionais que permitem visualizações científicas, interatividade e manipulação;

5. Internet refere-se à utilização do computador em rede que pode incluir a exploração de simulações, multimídias e realidade virtual.

Existem outros trabalhos de pesquisas que tratam do uso do computador para o ensino de Física e cada um aborda o assunto sob um determinado prisma; uns reportam-se a 
uma específica utilização, outros classificam seus diversos recursos e outros ainda apenas se preocupam com alguns recursos, tudo conforme o campo de interesse.

Nunes (2011), por sua vez, mapeou em sua tese, as produções acadêmicas que tinham como interesse a inserção do computador no Ensino de Física através de consultas em alguns catálogos on-line de periódicos, banco de teses e dissertações da Coordenação de Aperfeiçoamento de Pessoal de Nível Superior (CAPES) e anais de congressos, seminários e encontros relacionados ao Ensino de Física no Brasil. Esse trabalho de pesquisa contabilizou materiais produzidos entre 1997 e 2009, visto que a autora entende que o enfoque maior sobre as novas tecnologias no ensino, principalmente sobre os recursos computacionais, originou-se a partir da Lei de Diretrizes e Bases da Educação Nacional (LDB) de 1996.

Entre dissertações e teses (DIS/TES) foram localizados 701 trabalhos nesse período, sendo que 94 deles $(13,4 \%)$ tratavam da inserção do computador no Ensino de Física. No Caderno Brasileiro de Ensino de Física (CBEF), na Revista Brasileira de Ensino de Física (RBEF) e no seu suplemento semestral, Física na Escola (FnE), foram localizados no mesmo período, um total de 1351 trabalhos, sendo que 75 desses trabalhos $(5,6 \%)$ tratavam sobre o assunto de interesse. Pesquisando na Internet as revistas, que sob a concepção da autora são as mais interessantes sobre a Informática no Ensino: Revista Novas Tecnologias na Educação (RENOTE) e Revista Brasileira de Informática (RBIE), no mesmo período em um total de 729 trabalhos, apenas $10(1,4 \%)$ eram os de interesse da pesquisa. Nos encontros e simpósios de Ensino de Ciências, particularmente aqueles que visam ao Ensino de Física, nas atas/anais dos Encontros de Pesquisa em Ensino de Física (EPEF) e dos Simpósios de Ensino de Física (SNEF), no mesmo período, foram encontrados em um total de 714 trabalhos, 182 (25,5\%) sobre o assunto de pesquisa em discussão nesta dissertação.

\begin{tabular}{|c|c|c|c|}
\hline \multicolumn{4}{|c|}{ PESQUISA REALIZADA DE 1997 a 2009 } \\
\hline FONTE & $\begin{array}{c}\text { TRABALHOS SOBRE } \\
\text { ENSINO DE FÍSICA }\end{array}$ & $\begin{array}{c}\text { TRCURSOS COMPUTACIONAIS } \\
\text { NO ENSINO DE FISICA }\end{array}$ & $\%$ \\
\hline DIS / TES & 701 & 94 & 13,4 \\
\hline CBEF /RBEF / FnE & 351 & 75 & 5,6 \\
\hline RENOTE / RBIE & 729 & 10 & 1,4 \\
\hline EPEF / SNEF & 714 & 182 & 25,5 \\
\hline TOTAIS & 3.495 & 361 & 10,3 \\
\hline $\begin{array}{l}\text { - Dissertações e Teses (DIS/TES) } \\
\text { - Caderno Brasileiro de Ensino de Física (CBEF) / Revista Brasileira de Ensino de Física (RBEF) / Física na Escola (FnE) } \\
\text { - Revista Novas Tecnologias na Educação (RENOTE) / Revista Brasileira de Informática (RBIE) } \\
\text { - Encontros de Pesquisa em Ensino de Física (EPEF) / Simpósios de Ensino de Física (SNEF) }\end{array}$ \\
\hline
\end{tabular}

(Quadro 2 - Resumo dos dados da Pesquisa de NUNES (2011) 
Dessa forma, verifica-se que em um total de 3495 trabalhos pesquisados no período de 1997 a 2009, apenas 361, ou seja, aproximadamente 10,3\% tinham como interesse a inserção do computador no Ensino de Física. Esses 361 trabalhos foram divididos pela autora em 10 categorias, abaixo elencadas, que envolvem os diferentes modos de aplicação do computador no Ensino de Física:

1. Revisão de Estudos: trabalhos que abordam resenhas históricas, pesquisas bibliográficas e reflexões sobre o uso das tecnologias de informação e comunicação e Educação a Distância no Ensino de Física;

2. Modelagem/Simulações computacionais e programas tutoriais: abordam atividades desenvolvidas em um ambiente de modelagem computacional;

3. Aquisição automática e análise de dados em tempo real: trabalhos que abordam assuntos sobre o uso de interfaces de microcomputadores para a coleta e análise de dados em atividades de laboratório;

4. Recursos Multimídia: trabalhos que abordam o desenvolvimento e avaliação de hipermídia na forma de cursos, módulos e tópicos de Física; digitalização de vídeo e produções de home-page.

5. Comunicação a Distância: trabalhos que abordam a elaboração de cursos de Física a distância.

6. Resolução algébrico-numérica e estudo de soluções matemáticas: trabalhos que abordam a modelagem matemática para a resolução de problemas de Física;

7. Animação Gráfica: trabalhos que abordam a elaboração de roteiros, desenvolvimento, aplicação e análise de sofwares, applets, sites educacionais, simulações computacionais;

8. Ambientes Virtuais de Aprendizagem: trabalhos que abordam a concepção, modelização, desenvolvimento e análise de ambientes virtuais de aprendizagem;

9. Visão discente: trabalhos que abordam a visão que os estudantes têm em relação à inserção do computador e do laboratório virtual no Ensino de Física; e

10. Recursos da Internet: trabalhos que tratam da abordagem baseada em atividades de pesquisa, simulações, vídeo e outros recursos encontrados na internet para o apoio do Ensino de Física.

Para o presente trabalho foram criadas três categorias que sintetizam os diversos recursos didáticos que os artefatos computacionais possuem e que auxiliam no Ensino de Ciências, apoiadas nas cinco modalidades do uso de computadores no ensino de Física 
apontadas por Fiolhais \& Trindade (2003) e também nas dez categorias que envolvem os diferentes modos de aplicação do computador no Ensino de Física, apontadas por Nunes (2011). Essas três categorias são: Modelagem Computacional, Multimídia Computacional e a Internet.

Dependendo da utilização que o professor faça desses recursos dos artefatos computacionais, sua ação pode incluir-se nessas três classificações criadas por nós. Por exemplo, quando um professor pesquisa um determinado assunto na internet, essa sua ação está classificada como Internet. Quando ele, de posse de tais informações produz uma apresentação em PowerPoint ou um filme, ele está utilizando-se dos recursos classificados como Multimídia Computacional. Se ele ainda desenvolver com esse material uma atividade investigativa ou até mesmo de experimentação, está utilizando os recursos classificados como Modelagem Computacional.

\subsubsection{Uso da Modelagem Computacional}

Criamos esta categoria inspirados nas modalidades de Fiolhais \& Trindade (2003): "modalidades da aquisição de dados por computador"; da "modelagem e simulação"; e da "realidade virtual" e nas categorias propostas por Nunes (2011): "modelagem/simulações computacionais e programas tutoriais"; "aquisição automática e análise de dados em tempo real"; "resolução algébrico-numérica e estudo de soluções matemáticas"; "animação gráfica"; "ambientes virtuais de aprendizagem" e "visão discente".

Entende-se que a Modelagem Computacional é a área da Ciência Computacional que trata das soluções de problemas científicos através de simulações, permitindo a análise dos fenômenos, o desenvolvimento dos modelos matemáticos para sua descrição e a elaboração de códigos computacionais para obtenção dessas soluções. Propicia a construção e simulação de modelos de fenômenos físicos, a partir das equações matemáticas que representam esses fenômenos. Deste modo, quando o aluno descreve o modelo matemático que traduz um determinado fenômeno, a modelagem computacional permite simulações computacionais de tal fenômeno e, dessa forma, possibilita uma análise diferenciada que favorece uma maior compreensão do conteúdo, contribuindo para o desenvolvimento cognitivo (VASCONCELOS et al, 2003). As simulações não substituem por completo a 
realidade que representam, mas são úteis para demonstrar experiências difíceis ou impossíveis de realizar na prática por serem caras, perigosas, muito lentas ou muito rápidas.

Muitos experimentos científicos baseados em cálculos matemáticos são complexos e trazem dúvidas e dificuldades aos alunos. $\mathrm{O}$ uso dos artefatos computacionais pode auxiliar na solução desses cálculos, oferecendo também a possibilidade de visualizar, analisar e refletir sobre os dados e modelos apresentados. Atividades bem estruturadas, o ensino assistido por computador e a orientação do professor formam o trio que pode constituir um meio didático que pode levar os alunos a descobrirem o papel que a linguagem matemática possui para descrever a Ciência.

Por meio do uso de modelos matemáticos inseridos em um ambiente computacional, é possível auxiliar ao aluno resolver uma situação, visualizar um fenômeno e refletir sobre o significado do problema proposto, diminuindo a grande quantidade de tempo demandada com os cálculos, direcionando a atenção para a parte mais importante da atividade, que é a análise das representações dos fenômenos físicos. Muitos experimentos científicos baseados em cálculos matemáticos são complexos e trazem dúvidas e dificuldades aos alunos, mas a utilização dos artefatos computacionais pode permitir a solução desses cálculos, encarregando-se de resolver suas complexidades e oferecendo a possibilidade de visualizar, refletir sobre os dados e modelos e analisá-los. Atividades bem estruturadas e o ensino assistido por artefatos computacionais constituem um meio didático que pode levar os alunos a conhecerem o papel estruturador da matemática nas Ciências.

Dessa forma, pode-se levar o aluno a refletir sobre conceitos, fórmulas e equações, desenvolvendo a capacidade de raciocinar criticamente sobre os conteúdos. A utilização de ambientes virtuais em aulas de Ciências, com simulações e ilustração de fenômenos físicos podem ser capazes de propiciar ao aluno a difusão do conhecimento e propiciar a ele uma educação de qualidade, com experiências diferentes daquelas oferecidas pelas aulas tradicionais.

\subsubsection{Uso da Multimídia Computacional}

Criamos esta categoria inspirados pela modalidade de Fiolhais \& Trindade (2003), “materiais multimídia” e pela categoria de Nunes (2011): "recursos multimídia”. 
De acordo com a UNCG, University of North Carolina Greensboro ${ }^{3}$, o termo multimídia corresponde à integração de diferentes modalidades de mídia que podem ser agrupados em cinco itens básicos: texto, som, imagem, animação e vídeo. Uma linguagem eletrônica produzida com Artefatos Computacionais unem essas diferentes linguagens com a qual o usuário pode interagir. Dessa forma, entendemos que a Multimídia Computacional é uma variedade de recursos disponibilizados pelos artefatos computacionais que permitem a edição de textos, sons, imagens, vídeos etc, como exemplo as Ferramentas do Microsoft Office: Word, Excel, PowerPoint, Windows Media Player, Paint e outros, que podem ser usados por professores e alunos conforme seus interesses, selecionando-os através de ícones.

A multimídia contribui para o aprendizado individual pela interatividade e pela flexibilidade na escolha do caminho a seguir, disponibilizando a alunos e professores diversas possibilidades que permitem que o processo seja participativo e ativo no ambiente de aprendizagem. A multimídia propicia a busca da informação onde ela estiver armazenada: na Internet, no Disco Rígido, Pen Drive, CD, HD e outros, e tem um papel motivador para o aluno, cabendo ao professor orientá-lo para a busca de informações relevantes para o aprendizado, ou seja, são tecnologias com suporte digital para criar, manipular, armazenar e pesquisar.

A multimídia não é apenas uma maneira de apresentar informações a professores e alunos, como se eles fossem meros receptores passivos. Multimídia é uma forma que o usuário tem para ativamente interagir com as informações: buscando-as, recuperando-as, interligando-as, construindo com elas novas informações, deixando de ser simples observador passivo da exposição das informações, mas tornando-se manipulador e processador dessas informações. O professor pode: decidir a sequência em que a informação vai ser apresentada ou recuperada; determinar o ritmo e a velocidade da apresentação ou recuperação da informação; controlar repetições, avanços, interrupções, sempre podendo retomar o ponto em que parou na vez anterior; estabelecer associações e interligações entre informações diversas, mesmo que de natureza diferente (textos, imagens e sons, por exemplo), progredindo de um assunto ao outro, ou saltando de um meio ao outro, sem desviar-se de seu objetivo pedagógico; introduzir marcações e anotações nos textos e imagens, bem como comentários ao material produzido, podendo também realizar cálculos com informações numéricas eventualmente inseridas nos textos; definir os momentos em que, se desejar, pode avaliar seu

\footnotetext{
${ }^{3}$ http://library.uncg.edu/services/multimedia_services.aspx
} 
conhecimento, determinando, assim, se já possui as informações de interesse, além de interagir com informações representadas por mídias que não são tradicionalmente interativas (fotografia, vídeo, música, voz gravada), ou seja, podem ser associadas ao computador e passarem a ser interativas.

O usuário de multimídia pode interagir com o sistema, tocando na tela ou através de um mouse que é um pequeno aparelho, usado com o teclado ou mesmo no lugar dele, que permite ao usuário manipular a tela do microcomputador, sem tocá-la, apenas movendo o aparelhinho em cima da mesa e, dessa forma, acrescentando uma dimensão táctil à multimídia não apenas áudio-visual.

\subsubsection{Uso da Internet}

Esta categoria foi criada por inspiração da modalidade proposta por Fiolhais \& Trindade (2003), "busca de informações na internet" e das categorias de Nunes (2011): "revisão de estudos"; "comunicação a distância" e "recursos da internet".

A Internet também é outro meio que pode auxiliar no processo de ensinoaprendizagem visto que oferece para o trabalho do professor inúmeros recursos que facilitam as suas tarefas como: a de preparar aulas, fazer trabalhos de pesquisa e relacionamento com alunos fora do horário de aula; além de oferecer materiais atraentes para apresentações e subsídios teóricos que alicerçam suas aulas. Além de constituir-se um meio de relevantes possibilidades pedagógicas, permite que os trabalhos de pesquisa sejam compartilhados por outros alunos e divulgados instantaneamente em rede, para quem se interessar, extrapolando os limites que os muros da escola impõem.

A primeira geração da internet, Web 1.0, destacou-se pela enorme quantidade de informação disponível a todos, porém os internautas figuravam como consumidores de informações, visto que não podiam alterar ou reeditar o seu conteúdo. Nessa primeira fase, surgiu e proliferou a velocidade dos serviços disponibilizados por meio da rede, criando-se novos empregos e nichos econômicos. A grande maioria dos serviços eram pagos e controlados por meio de licenças, os sistemas eram restritos a quem detinha poder de compra para custear as transações "on line" e adquirir o "software" para criação e manutenção de sites. A web 1.0 trouxe grandes avanços no que diz respeito ao acesso à informação e ao conhecimento, porém a filosofia que estava por detrás do conceito de rede global foi sempre a 
de um espaço aberto a todos, ou seja, sem uma pessoa ou empresa específica que controlasse o acesso ou o conteúdo publicado. Houve sempre a preocupação de tornar esse meio cada vez mais democrático e a evolução tecnológica permitiu o aumento do acesso de utilizadores (COUTINHO, 2007).

A segunda geração da World Wide Web, denominada Web 2.0, trouxe a mudança de paradigma da Web 1.0 e foi tão rápida que passou desapercebida por muitos utilizadores. Hoje em dia, a filosofia é outra, as pessoas passaram a produzir os seus próprios documentos e a publicá-los automaticamente na rede, sem a necessidade de grandes conhecimentos de programação e de ambientes sofisticados de informática. As principais características da Web 2.0 são: Interfaces ricas e fáceis de usar; gratuidade na maioria dos sistemas disponibilizados; maior facilidade de armazenamento de dados e criação de páginas "on line"; vários utilizadores podem aceder à mesma página e editar as informações; as informações mudam quase que instantaneamente; os sites e softwares estão associados a outros aplicativos, tornando-os mais ricos e produtivos; os sistemas param de ter versões e passam a ter atualizações; pode-se criar comunidades de pessoas interessadas em um determinado assunto, atualizadas constantemente (COUTINHO, obra citada). A Web 2.0 permite uma democratização no acesso e no uso da informação: Blogs, Youtube, Googlepages, Wikipédia, Facebook, entre outros serviços, contribuem para a interatividade e para o aumento do potencial inovador da Internet conforme o número de usuários vai aumentando. São essas ferramentas da Web 2.0 que, integradas à sala de aula, podem auxiliar os alunos na construção do conhecimento, visto que o uso de artefatos computacionais na escola seria a continuidade do seu uso doméstico, por assim dizer, mas com fins pedagógicos.

Podemos observar que a internet está sendo utilizada no ensino, em pesquisas, lazer, informação, trabalho, negócios, serviços entre outros. Como usuário, é possível observar por seus aspectos pedagógicos inerentes, que a Internet dá acesso a um enorme número de informações difundidas por todo o mundo, que crescem e atualizam-se exponencialmente. A qualidade dessas informações, conforme diversos critérios, podem transitar de um polo a outro, mas se selecionadas, contribuem infinitamente para a construção do conhecimento com informações valiosas.

Segundo MORAN (2002), o professor no seu papel de orientador pode conduzir o aluno neste vasto universo que é a Internet e o aluno, por sua vez, pode motivar e passar a compreender a importância do seu papel no processo de ensino e aprendizagem. $\mathrm{O}$ aluno pode 
ser instigado a desenvolver trabalhos bem elaborados, visto que serão divulgados e estarão à disposição para acesso e para a pesquisa de todos. Esse fato pode levá-lo a procurar estar sempre construindo cada vez mais, tendo como referência os trabalhos divulgados dos demais alunos que podem servir de fontes inspiradoras.

A Internet tem o poder de favorecer o contato entre as pessoas, promovendo a integração, o debate de temas comuns, o estabelecimento de laços sociais e a relação entre diversas culturas globalizando-as. Com o avanço tecnológico galopante e com incontáveis informações à disposição, a figura do professor como um mero transmissor de informação perde o sentido. Nesse contexto, o professor pode assumir a figura de orientador que conduz o aluno a pensar, direcionando-o a transitar nesse universo e por entre as galáxias de informação, à procura das que sejam relevantes para a construção do seu conhecimento.

Assim, a Internet pode permitir um trabalho conjunto de professores e alunos na disponibilização de textos, análise de pesquisas e dos principais acontecimentos relacionados à disciplina e também facilitar a interdisciplinaridade, com chances de integração entre várias áreas, vários professores, enfim, toda a escola. É uma mídia que pode facilitar a motivação dos alunos diante do deslumbramento com tantas possibilidades inesgotáveis de pesquisa oferecidas (MORAN, obra citada).

Essa motivação pode aumentar se o professor criar um clima de confiança, de abertura e de cordialidade com os alunos, estabelecendo uma relação de confiança, por meio da competência e simpatia com que atua. A Internet pode ainda permitir a pesquisa individual, em que cada aluno trabalha no seu ritmo ou em grupo, possibilitando a divulgação de páginas pessoais ou de grupos, o que gera uma grande motivação, visibilidade e responsabilidade para professores e alunos, que se esforçam para divulgar o melhor (MORAN, obra citada).

Observa-se que a Internet na escola possibilita uma expansão para além das paredes das bibliotecas, devido à ligação que possui com as fontes de informação. $\mathrm{O}$ trabalho com a Internet pode se constituir um meio de relevantes possibilidades pedagógicas, além de permitir que os trabalhos de pesquisa sejam compartilhados por outros alunos e divulgados instantaneamente em rede para quem quiser. Alunos e professores encontram inúmeros recursos que facilitam a tarefa de preparar as aulas, fazer trabalhos de pesquisa e ter materiais atraentes para apresentação. O professor pode estar mais próximo do aluno, podendo adaptar a sua aula para o ritmo de cada um. O processo de ensino-aprendizagem pode ganhar, assim, um dinamismo, uma inovação e um poder de comunicação inusitados. 
Além disso, o professor e os alunos podem comunicar-se dentro do período de aulas ou fora dele. A relação pedagógica assentada na ação discursiva do professor pode passar a ser superada por ações que demandam envolvimento e participação para projetar, criar e produzir conhecimento. Nesse novo movimento, o professor pode passar a perceber talentos nos alunos que, no paradigma conservador, mantinham-se silenciados na sala de aula.

As atividades didáticas que contemplam a tecnologia da informação podem permitir ao aluno ir além da tarefa proposta, cada um no seu ritmo de aprendizagem. A inovação não está restrita somente ao uso da tecnologia, mas também à maneira como o professor apropria-se desses recursos para criar projetos metodológicos que superem a simples reprodução e levem à produção do conhecimento novo. Os ambientes telemáticos de aprendizagem permitem programar uma rede de informações interligadas, em que os sujeitos podem explorar diferentes mídias simultaneamente e integrá-las em uma mesma atividade. A Internet não oferece apenas recursos de pesquisa ao interessado em estudar, mas se constitui numa poderosa ferramenta de trabalho para atuar em ambientes educacionais. Qualquer site pode ser educativo, desde que os conteúdos presentes sejam avaliados como tal.

\subsection{Objetos Virtuais de Aprendizagem}

Não há uma definição universalmente aceita para Objetos Virtuais de Aprendizagem, existindo diferentes definições para esse conceito, o que resulta em confusão e dificuldade de comunicação principalmente por ser um campo de estudo novo. Em nosso entendimento, os objetos virtuais de aprendizagem podem ser compreendidos como qualquer recurso digital que possa ser utilizado para o suporte ao ensino e que tenha um propósito educacional bem definido com elementos que estimulem a reflexão do aluno e que sua aplicação não se restrinja a um único contexto, formando um ambiente de aprendizado rico e flexível, onde o professor pode acompanhar o aluno dando sugestões e orientações com plena liberdade de uso, sem depender de estruturas rígidas e estáticas, conforme a sua necessidade e a proposta de ensino que quer focar (WILEY, 2000).

Qualquer uma das três categorias criadas por nós (Modelagem Computacional, Multimídia Computacional e Internet), que sintetizam os diversos recursos didáticos que os artefatos computacionais possuem e que auxiliam no Ensino de Ciências, pode ser considerada como um objeto virtual de aprendizagem. Desta forma, um objeto virtual de 
aprendizagem é um recurso digital que auxilia na aprendizagem, além de estimular a imaginação e a criatividade. Um objeto virtual de aprendizagem pode tanto abordar um único conceito quanto toda uma teoria, focalizando apenas determinado aspecto do conteúdo envolvido ou toda a metodologia adotada para um determinado trabalho.

Projetos de educadores e pesquisadores de vários países têm sido financiados especialmente para elaborar objetos virtuais de aprendizagem, com o intuito de estudar os progressos dos alunos na construção do conhecimento. Nesses projetos, grupos formados por educadores, psicólogos, designers e programadores orientam professores e alunos na produção de simulações de situações reais, abordando conceitos das diversas disciplinas do currículo. Dentre os projetos mais conhecidos, destacam-se o projeto Training and Resources for Assembling Intentional Learning Systems - TRAILS - (http://www.trails-project.org); o projeto ESCOT - Educational Software Components for Tomorrow (http://www.ctl.sri.com/index.jsp); ou, aqui no Brasil, o projeto do Laboratório Didático Virtual da Escola do Futuro da USP (http://www.labvirt.futuro.usp.br) e o projeto do MEC, RIVED - Rede Internacional Virtual de Educação - (http:// http://rived.mec.gov.br).

Um objeto virtual de aprendizagem não se resume apenas à simulação de um experimento real, é muito mais do que isso, o aluno é envolvido por todo um contexto que lhe exige a compreensão de determinados conceitos científicos. Para sabermos se o objetivo da atividade foi alcançado, devemos observar o ponto de vista de quem o projetou e o ponto de vista de quem o utilizou. O sucesso de quem o utiliza está diretamente relacionado ao aprendizado pessoal dos conceitos envolvidos no objeto.

Os resultados do aprendizado merecem uma reflexão mais detalhada dos envolvidos na elaboração e execução de um objeto virtual de aprendizagem. Este movimento mobiliza uma série de recursos pessoais de professores e alunos, no entanto, o mais importante é refletir sobre o processo criativo que está por detrás dessa atividade intelectual. Professores e alunos envolvidos na elaboração dos objetos, partindo do olhar sobre a realidade da aplicação dos conceitos, definem suas metas idealizando um contexto para o desenvolvimento da atividade, selecionando as informações relevantes que possuem e pesquisando sobre as que ainda não possuem. Em seguida, traçam um roteiro de produção, acompanham a programação, avaliam os resultados e por último, conduzem à aplicação do objeto junto aos demais colegas (BETTIO \& MARTINS, 2004). 
Estratégias de trabalhos que favoreçam a criatividade dos alunos não é privilégio daquelas que se utilizam de artefatos computacionais, como podemos observar no aprendizado de nossos pais e de muitos de nós que não vivemos na escola a era da informática, mas o uso inteligente dos instrumentos de tecnologia, bem como as produções de objetos virtuais de aprendizagem ampliam o campo de possibilidades para o desenvolvimento da capacidade criativa dos alunos. 


\section{Capítulo III - Saberes docentes e formação de professores}

O saber é sempre o saber de alguém que trabalha alguma coisa no intuito de realizar um objetivo qualquer. Além disso, o saber não é uma coisa que flutua no espaço: o saber dos professores é o saber deles e está relacionado com a pessoa e a identidade deles, com sua experiência de vida e com sua história profissional, com suas relações com os alunos em sala de aula e com os outros atores escolares na escola etc. Por isso é necessário estudá-lo relacionando-o com esses elementos constitutivos do trabalho docente. (TARDIF, 2002, p.11).

$\mathrm{Na}$ presente dissertação não se tem a intenção de esgotar ou aprofundar de forma absoluta os diferentes entendimentos que possam existir por diversos autores sobre os saberes docentes. O objetivo é o de entender as relações que existem entre os saberes do professor e seu trabalho com os Artefatos Computacionais e, assim, entender melhor como esses saberes manifestam-se nesse movimento. Como norte, recorremos a Tardif (2002) com o intuito de abranger, sob sua óptica a natureza dos saberes docentes, sua importância, como são adquiridos e qual a relação desses saberes com o trabalho docente mediado por este Instrumento Cultural.

Não basta apenas existirem escolas equipadas com o que há de mais moderno em Artefatos Computacionais, se não tiver professores convencidos de que a informática está presente na vida de seus alunos e que saibam aproveitar o potencial desses equipamentos como instrumento de ensino-aprendizagem. O professor pode aprender ensinando, quando utiliza Artefatos Computacionais em suas aulas, sendo importante refletir sobre sua prática por meio de discussões com seus pares sobre a inclusão dessas tecnologias em sala de aula e as consequentes alterações que possam ocorrer no ensino e na aprendizagem.

Por essa perspectiva, deve-se ver a função de professor como uma profissão e, segundo Tardif (obra citada), para que efetivamente ocorra esta profissionalização, devem ser introduzidos na formação docente conhecimentos específicos inerentes à profissão de professor. Desta forma, sua formação universitária deve focar a solução de problemas pertinentes à educação, formando professores capazes de intervirem e auxiliarem na aprendizagem dos alunos, principalmente daqueles que apresentam maiores dificuldades de aprendizagem. Sua profissionalização deve visar torná-lo um profissional de educação capaz de encontrar soluções para as dificuldades pedagógicas com as quais se deparar no decorrer de sua carreira. $\mathrm{O}$ professor aprimora-se profissionalmente, à medida que reflete sobre sua 
prática no ambiente escolar e a articula com os conhecimentos adquiridos em sua formação universitária, o que pode contribuir para a sua formação continuada.

$\mathrm{O}$ autor admite que o processo de profissionalização consiste em uma tentativa de rever e aprimorar os alicerces epistemológicos da profissão de professor e, desta forma, por meio de uma análise desses fundamentos, tenta tirar daí elementos que permitam refletir a respeito da formação dos professores. A epistemologia estuda a origem, a estrutura, os métodos e a validade do conhecimento, e o autor, define epistemologia da prática profissional da seguinte forma:

Chamamos de epistemologia da prática profissional o estudo do conjunto dos saberes utilizados realmente pelos profissionais em seu espaço de trabalho cotidiano para desempenhar todas as suas tarefas (TARDIF, 2002, p.255)

Desta forma, o autor dá para o conceito de saber a seguinte significação:

[...] um sentido amplo que engloba os conhecimentos, as competências, as habilidades (ou aptidões) e as atitudes, isto é, aquilo que muitas vezes foi chamado de saber, saber-fazer e saber-ser" (id. ib., p. 255).

Neste sentido, a epistemologia da prática profissional tem por objetivo descobrir a natureza desses saberes, suas interações e como os professores no seu trabalho docente com os meios didáticos que possuem, elaboram-nos, apropriam-se deles, utilizam-nos e os modificam. Segundo esse autor, a epistemologia da prática pode modificar as concepções atuais das pesquisas sobre formação de professores e aponta seis consequências que podem ser importantes para esse novo campo de pesquisa.

A primeira consequência seria a de que os saberes profissionais referem-se aos saberes trabalhados, realizados, incorporados durante a atividade docente que são construídos, modelados e utilizados de maneira significativa pelos professores; sendo o professores, sua prática e seus saberes considerados um só corpo que evolui e se transforma. Para estudar os saberes profissionais, é necessário associá-los a uma situação de ensino, levando-se em consideração a atividade do professor e os saberes por ele mobilizados.

Assim sendo, a segunda consequência seria a de que os saberes profissionais não devem ser confundidos com os conhecimentos transmitidos na formação universitária e, dessa forma, a prática de ensinar não é um momento de aplicação dos conhecimentos universitários, mas sim um processo em que o professor, na melhor das hipóteses, em um ambiente concreto 
da realização do trabalho docente, tem a possibilidade de transformar esses conhecimentos, em conhecimentos significativos que atendam às necessidades dos alunos.

A terceira consequência seria a de que os saberes profissionais devem ser estudados diretamente no local onde são exercidas as práticas docentes, verificando como esses profissionais pensam, trabalham e interagem com os demais componentes do meio profissional onde estão inseridos.

Por sua vez, a quarta consequência seria a de que os professores têm suas atividades determinadas em parte pelas estruturas sociais, pela cultura dominante e pelo inconsciente, mas são práticos e possuem saberes e um saber-fazer e, no transcorrer do seu trabalho, demonstram competências significativas para atingir seus objetivos.

Como quinta consequência, o autor aponta que a visão sociopolítica dos pesquisadores de ciências historicamente construída a respeito da função dos professores não tem como objetivo o que eles são, fazem e sabem realmente e assim constroem opiniões divergentes das práticas educativas.

A sexta e última consequência seria a constatação da necessidade de estudar o conjunto dos saberes mobilizados e utilizados pelos professores em todas as suas tarefas do dia a dia, o que pode fazer surgirem as construções dos saberes docentes a partir de suas próprias práticas. O conhecimento do conteúdo e o da metodologia a ser utilizada são conhecimentos importantes, porém não abrangem todos os saberes dos professores no seu trabalho.

Sendo assim, podemos dizer que os conhecimentos profissionais estão em constante evolução e, desse modo, o profissional da educação necessita, constantemente, aprimorar-se após sua formação universitária inicial. Este aprimoramento pode ser conseguido por meio de cursos de formação continuada que o levem a interagir com outros profissionais da sua área, dando a ele oportunidade de avaliar seu trabalho e de compartilhar ideias que o levem a refletir, propiciando discernimento para adaptar e improvisar em situações novas, para que possa alcançar os objetivos que atendam às necessidades dos seus alunos.

Devido às funções que exercem, os professores ocupam uma posição fundamental na produção e na mobilização de saberes. A relação dos docentes com os saberes não se resume simplesmente na transmissão de conteúdos previamente construídos, mas na verdade 
compõem-se de diversos saberes provenientes de diferentes fontes, classificados por Tardif como: saberes profissionais, disciplinares, curriculares e experienciais.

Segundo Tardif (obra citada), os Saberes da Formação Profissional são os saberes provenientes da articulação entre da formação inicial e continuada dos professores. São caracterizados pelo conjunto dos saberes oriundos das instituições de formação de professores, que não se limitam apenas em produzir conhecimentos, mas procuram também incorporá-los às práticas docentes, ou seja, são produzidos pela universidade e instituições de ensino e, por conseguinte, são apropriados pelo professor durante sua formação. Esses saberes são provenientes das ciências da educação e dos saberes pedagógicos elaborados por meio das reflexões sobre as práticas educativas.

Já os Saberes Disciplinares são os derivados dos diversos campos do conhecimento que estão incorporados na universidade, por meio do estudo das diversas disciplinas que compõem os cursos de formação e que foram constituídas devido à cultura e aos grupos sociais responsáveis pela produção do saber. Costumeiramente, caracterizam-se por não apresentarem vínculos com as disciplinas da Faculdade de Educação e os cursos de formação de professores, ou seja, apresentam-se de forma independente.

Os Saberes Curriculares são os que são apropriados pelos professores durante sua vida profissional, por meio dos programas curriculares, dos programas de ensino e dos livros didáticos, materializados pelos dos discursos dos objetivos, dos conteúdos e dos métodos. Assim, apresentam-se concretamente sob a forma de propostas curriculares e das abordagens metodológicas apresentadas pelo governo bem como pelo próprio livro didático.

Por sua vez, os Saberes Experienciais são aqueles elaborados pelos professores por meio do trabalho docente e do convívio profissional com seus pares, a fim de encontrarem soluções para os problemas que surgem em sala de aula diariamente, constituindo dessa forma, um processo de aprendizagem por meio do qual os professores adaptam sua formação às práticas docentes, desenvolvendo determinadas informações e formas de agir. Esses saberes não são oriundos das instituições de formação nem dos currículos, mas da experiência docente e das relações que envolvem o seu trabalho.

Nesse contexto, a prática docente pode ser vista como um processo complexo que exige profissionalismo e que precisa ser repensado, devido a sua grandiosidade. O saber não é capaz de caracterizar e qualificar as capacidades cognitivas do indivíduo, nem muito menos 
funcionar como um simples organizador da ação pedagógica do professor. A capacidade profissional dos professores está diretamente ligada às reflexões sobre sua própria prática, buscando fundamentá-la em razões sociais no contexto em que esteja inserido (GALINDO, 2007).

Sobre o perfil ideal do professor profissional, Tardif esclarece que:

O professor ideal é alguém que deve conhecer sua matéria, sua disciplina e seu programa, além de possuir certos conhecimentos relativos às ciências da educação e à pedagogia e desenvolver um saber prático baseado em sua experiência cotidiana com os alunos. (TARDIF, 2002, p. 39).

Como características dos saberes profissionais docentes, o autor elenca os seguintes atributos: eles são temporais, variados e heterogêneos, personalizados e situados e que carregam as marcas do ser humano que os porta.

A característica de temporalidade refere-se ao fato de que os saberes profissionais docentes são adquiridos durante o percurso do tempo. Primeiramente, porque boa parte do que os professores sabem sobre como ensinar provém da bagagem histórica que adquiriu em sua vida pessoal e profissional e, mesmo após frequentar cursos de formação de professores, nem sempre modificam suas concepções anteriores sobre o ensino, que utilizam para resolver as dificuldades profissionais que lhe forem apresentadas. Em segundo lugar, os saberes também são temporais no sentido de que o início da carreira profissional é decisivo para a aquisição de suas competências e para a estruturação da sua prática profissional, que é quando o professor aprende na prática, por meio de seus erros e acertos. Num terceiro sentido, os saberes profissionais são temporais visto que são utilizados e desenvolvem-se durante uma carreira, durante um processo de maturação da vida profissional.

Quanto à característica de serem variados e heterogêneos, primeiramente refere-se ao fato de que os saberes profissionais provêm de diversas fontes, entre elas: as da história da vida e da cultura escolar que já vivenciou; dos conhecimentos disciplinares adquiridos em sua formação inicial e continuada; dos conhecimentos curriculares das escolas onde lecionou, dos livros didáticos e dos programas governamentais; e do seu próprio saber ligado às suas experiências de trabalho e às de outros professores. Numa segunda perspectiva, os saberes profissionais são variados e heterogêneos devido ao fato de os professores utilizarem o que têm à mão: teorias, concepções, técnicas e outros, mesmo que não sejam aceitas pela academia, para que possam suprir obstáculos que lhes impeçam de atingir seus objetivos. Finalmente, os saberes profissionais são variados e heterogêneos, porque os professores em 
suas práticas profissionais, ao mesmo tempo, procuram atingir diversos objetivos como: controlar e motivar os alunos; organizar e acompanhar atividades de aprendizagem e explicar, entre outras tarefas que evoluem durante a aula. O professor precisa desenvolver vários saberes visto que sua ação é direcionada para diferentes objetivos, entre eles, emocionais, motivacionais, sociais, cognitivos e coletivos entre outros. Desta forma, os professores são pragmáticos, lidam com diversos problemas ao mesmo tempo para os quais têm de dar soluções rápidas, enxergando mais soluções do que impedimentos.

Já a característica de serem personalizados e situados refere-se ao fato de que cada professor tem um contexto de trabalho, uma história de vida, experiências e pensamentos próprios e, desse modo, os saberes estão nele apropriados. Esse fato explica porque ao serem questionados sobre suas aptidões profissionais os professores relatam muitas vezes sobre sua personalidade e sobre suas desenvolturas profissionais como sendo estas, os fatores principais do sucesso do seu trabalho. Além disso, por lidarem com seres humanos em suas atividades habituais contam com suas próprias experiências para organizar o seu ambiente de trabalho. Assim, os saberes são situados, pois são construídos e utilizados em função de uma situação de trabalho particular, sendo os saberes, nesse contexto, construídos pela interação entre professores e alunos.

Por último, os saberes carregam as marcas do ser humano, visto que os professores trabalham com seres humanos, o que reporta a duas observações: primeiramente, a de que os seres humanos têm a característica de existirem como indivíduos, mesmo que estejam inseridos em algum grupo, o que leva o professor a ter como objetivo atingir cada aluno individualmente, embora esteja este aluno em uma sala de aula. Dessa forma, o professor deve ter a percepção e a sensibilidade de conhecer cada aluno individualmente, evitando generalizações, sendo esta uma das principais características do trabalho docente. A segunda observação é o fato de o saber profissional permitir elementos éticos e emocionais, visto que o ensino e o trabalho constantes do professor são práticas profissionais que produzem mudanças emocionais e de valores, que influenciam na sua maneira de ensinar. $\mathrm{O}$ aluno, por sua vez, também é um ser humano e deles devem ser obtidos aceitação e colaboração para que o clima emocional na sala de aula propicie a aprendizagem e ele sinta-se motivado. Essa atividade de motivar os alunos surge das interações humanas, tanto emocionais, quanto sociais que ocorrem na sala de aula.

O autor resume essa dimensão da seguinte maneira: 
[...] uma perspectiva epistemológica e ecológica do estudo do ensino e da formação para o ensino permite conceber uma postura de pesquisa que leva ao estudo dos saberes docentes tais como são mobilizados e construídos em situações de trabalho. Os trabalhos realizados de acordo com essa perspectiva mostram que os saberes docentes são temporais, plurais e heterogêneos, personalizados e situados, e que carregam consigo as marcas do seu objetivo, que é o ser humano (TARDIF, 2002, p. 269).

O autor esclarece, ainda, que existem inúmeros livros e trabalhos que apontam diversas tipologias e categorias para os saberes docentes e apesar de não terem nenhuma modéstia em utilizar este termo, não lhe dão uma noção clara.

Na verdade ninguém é capaz de produzir uma definição de saber que satisfaça todo mundo, pois ninguém sabe cientificamente, nem com toda certeza, o que é um saber (TARDIF, 2002, p.193).

Ampliando a discussão desse tema, o autor aponta que no âmbito da cultura atual, o saber foi definido por meio de três concepções: subjetividade, julgamento e argumentação.

A concepção de subjetividade está associada ao sujeito e refere-se à certeza subjetiva produzida pelo pensamento racional e se opõe às certezas subjetivas baseadas na fé, nas crenças, nas convicções, nos preconceitos, nas dúvidas, nos erros, na imaginação e em outras. É uma intuição racional proveniente do pensamento lógico e do processamento de informações que resulta em uma cadeia de raciocínios. Saber alguma coisa é possuir uma certeza subjetiva racional.

Já a concepção do saber ligada ao juízo refere-se aos discursos resultantes de uma atividade intelectual, ou seja, o ato de julgar que afirma sobre a realidade de algo, excluindo dessa concepção de saber os juízos de valor, de vivência ou de engajamentos políticos. O juízo é emitido sobre alguma coisa percebida ou representada que pode ser considerado como verdadeiro ou falso. Diferente da concepção do saber ligada à subjetividade, esse tipo de saber reside no discurso e não no espírito subjetivo.

A concepção de saber ligada ao argumento é a que se harmoniza com as ideias de Tardif. Essa concepção consiste em tentar validar, por meio de argumentos, um fato ou uma ação que se desenvolve em um determinado espaço, com determinadas pessoas. O saber não é somente emitir um juízo verdadeiro ou falso sobre algo, mas também ser capaz de justificar por que razões esse juízo corresponde à realidade. É uma construção coletiva que tem como base a linguagem e é proveniente das interações sociais. 
O autor esclarece que os partidários da teoria da argumentação procuram elaborar uma ideia de saber que extrapola as concepções de juízo e subjetividade ao validar suas ideias e ações por meio do discurso, esclarecendo que:

$\mathrm{Na}$ argumentação, os interlocutores procuram ultrapassar os pontos de vista inicial de sua subjetividade, de suas palavras ou ações. Essa demonstração é feita por meio de argumentos e de contra-argumentos (TARDIF, 2002, p. 197).

Dessa forma, Tardif tenta validar, por meio da argumentação, uma suposição ou uma ação, determinando por quais razões têm esse juízo sobre alguma coisa, construindo pensamentos através do debate com outros sujeitos. Através da racionalidade que aparece nessas três concepções, o autor procura definir o saber dos professores. Essas concepções, apesar de possuírem importantes diferenças entre si, associam sempre à natureza do saber a exigência da racionalidade, ou seja, o pensamento racional de um sujeito; o ato racional de julgar; e, por último, a argumentação como o ato de formular e expor de modo racional as ideias.

Saber alguma coisa ou fazer alguma coisa de maneira racional é ser capaz de responder "por que você diz isso?" e "por que você faz isso?", oferecendo razões, motivos, justificativas susceptíveis de servir de validação para o discurso ou para a ação (TARDIF, 2002, p. 198).

Dessa maneira, obtém-se as razões, os motivos e as justificativas capazes de validar o discurso ou a ação, sendo que o sujeito sabe o "porquê" e "o como" se faz. Não basta saber fazer ou falar, tem que saber por que se faz e por que se fala. Desta forma, quando o professor não justifica suas ações e discursos, não podemos considerar como saber. O saber não está no sujeito, mas sim nas razões que ele apresenta para tentar validar sua fala e suas ações. Sobre esse fato o autor tem o seguinte ponto de vista:

A nosso ver, o saber não reside no sujeito, mas nas razões públicas que um sujeito apresenta para tentar validar, em e através de uma argumentação, um pensamento, uma proposição, um ato, um meio, etc (id., ibid., p. 206).

E define o saber docente da seguinte maneira:

[...] unicamente os pensamentos, as ideias, os juízos, os discursos, os argumentos que obedeçam a certas exigências de racionalidade. Eu falo ou ajo racionalmente quando sou capaz de justificar, por meio de razões, de declarações, de procedimentos, etc., o meu discurso ou minha ação diante de um outro ator que me questiona sobre a pertinência, o valor deles, etc (id., ibid., p. 199). 
Pelo acima exposto, ancorando-nos nas concepções do autor selecionado para o nosso objetivo de pesquisa, definimos saber docente como sendo todos os discursos e atos dos professores no seu trabalho que têm como origem o pensamento racional proveniente do pensamento lógico e do processamento de informações, justificando-os e validando-os através da argumentação com seus pares e alunos. Esses saberes são identificados quando o professor apresenta argumentos que os justificam e que os validem ou não.

Quando o sujeito é questionado sobre o porquê, sobre as causas, sobre as razões e sobre os motivos de seu discurso ou de sua ação, ele apresenta argumentos e motivos que podem justificar o seu comportamento, bem como também os motivos, as escolhas e as decisões que utiliza para alcançar seus objetivos, sendo que dessa forma, uma das principais estratégicas de pesquisa relacionadas com essa visão do saber consiste em observar, nos sujeitos e nas suas falas, os saberes que os levam a agir e raciocinar sob seus atos (AZEVEDO, 2008).

Tardif também trata do tema e aprofunda essa discussão:

Os saberes dos professores são, para nós, os saberes com fundamentos racionais, e não saberes sagrados: o valor deles vem do fato de poderem ser criticados, melhorados, tornar-se mais poderoso, mais exatos ou mais eficazes. (TARDIF, 2002, p. 206).

Os saberes dos professores estão relacionados ao que eles são, tanto emocionalmente quanto em relação à sua história de vida e ao que fazem profissionalmente. A utilização dos saberes pelos professores dá-se em função do seu trabalho e das relações sociais que ocorrem, não sendo essas relações estritamente cognitivas, mas sim mediadas pelo trabalho que lhe propiciam possibilidades de solucionar situações cotidianas. Os saberes dos professores estão sempre ligados a uma situação de trabalho com o outro e tem como objetivo o ato de ensinar num determinado ambiente. Segundo o autor,

O saber dos professores não é o "foro íntimo" povoado de representações mentais, mas um saber sempre ligado a uma situação de trabalho com outros (alunos, colegas, pais, etc), um saber ancorado numa tarefa complexa (ensinar), situado num espaço de trabalho (a sala de aula, a escola), enraizado numa instituição e numa sociedade. (Id., ibid., pag. 15).

Para ele, o professor simplesmente não deve transmitir os conhecimentos produzidos por outros, mas sim realizar seu trabalho com base nos conhecimentos que ele mesmo constrói, ou seja, é um profissional que tem um conhecimento e um saber-fazer provenientes de sua própria atividade, que é estruturada, organizada e orientada para a sua 
prática docente. Nesse contexto, o objetivo do estudo é conhecer o ponto de vista do professor, sua subjetividade e seus conhecimentos e, consequentemente, como os saberes profissionais desenvolvem-se e estruturam-se com a utilização de Artefatos Computacionais e seus recursos em seu trabalho docente. 


\section{Capítulo IV - Metodologia da pesquisa}

Os trabalhos que tratam do assunto sobre o uso pedagógico de Artefatos Computacionais muito nos interessam, visto ser esta uma questão, a nosso ver, importante para a educação devido à disseminação dessas tecnologias na sociedade e também pelo fato de que a sua inserção nas instituições escolares, aos poucos, vem ganhando espaço nos meios acadêmicos. Nesta pesquisa, em vez de um viés com enfoque motivacional, como realizamos em trabalhos anteriores, estamos voltados para os saberes que se apresentam no trabalho docente quando os professores fazem uso deste equipamento, sobre a perspectiva dos estudos de Tardif.

Creio que não seja possível pensar em formação de professores sem considerar as implicações que as tecnologias computacionais trazem para a educação. Esta pesquisa é de grande relevância para nós, cujo conteúdo e o problema de investigação perpassam a nossa formação como professor e pesquisador. A esse respeito, Lüdke e André (1986) comentam que: “... como atividade humana e social, a pesquisa traz consigo, inevitavelmente, a carga de valores, preferências, interesses e princípios que orientam o pesquisador” (p.3).

\subsection{Metodologia qualitativa}

A presente pesquisa possui uma metodologia qualitativa, visto que desenvolve-se em um ambiente onde há o contato direto e prolongado do pesquisador com a situação que está sendo investigada, sendo que os dados coletados são predominantemente descritivos e o interesse é o de estudar o problema proposto e verificar como ele se manifesta nas atividades, nos procedimentos e nas interações cotidianas. O foco é o de tentar capturar o ponto de vista dos pesquisados, por meio de suas percepções, não se preocupando com evidências que comprovem hipóteses pré-definidas, mas sim, à medida que o estudo se desenvolve, os focos e interesses que inicialmente eram muito amplos, tornam-se mais diretos e específicos (LÜDKE \& ANDRÉ, 1986).

Por sua vez, Duarte (2000) esclarece que na pesquisa qualitativa existe o contato direto e prolongado do pesquisador com o ambiente e com a situação que está sendo investigada, sem qualquer interferência intencional do pesquisador. $\mathrm{O}$ material obtido na 
pesquisa se constitui por descrições de pessoas, situações, acontecimentos, transcrições de entrevistas e outros documentos, sendo que o pesquisador se apega ao maior número possível de elementos que se apresentam na situação pesquisada.

Não estamos desprezando os demais procedimentos metodológicos de pesquisa, já que optamos pelo qualitativo, visto que nossa intenção não é o de contrapor o método qualitativo ao método quantitativo, apenas acreditamos que para a pesquisa que desenvolvemos o método qualitativo, conforme os autores acima o descrevem, seja o mais coerente, mas nada nos impede de recorrermos a gráficos ou tabelas que sistematizem e revelem quantitativamente alguns dados que julgarmos relevantes.

Partindo do princípio de que não há metodologias "boas" ou "más" intrinsecamente, e sim metodologias adequadas ou inadequadas para tratar um determinado problema... (ALVES, 1991, p.58)

O foco do pesquisador na metodologia qualitativa é o de verificar como um determinado problema se apresenta e se processa num determinado contexto. $\mathrm{O}$ seu ponto de vista, por estar junto aos sujeitos pesquisados, permite esclarecer determinados pontos e situações que geralmente quem está de fora não consegue perceber. $\mathrm{O}$ pesquisador tem como prioridade buscar elementos que comprovem suas hipóteses, a partir da análise dos seus dados. Desta forma, a pesquisa qualitativa possibilita a obtenção de dados a partir do contato direto do pesquisador com seu objeto de estudo, sendo esse fato a essência da pesquisa que retrata as expectativas dos pesquisados (LÜDKE \& ANDRÉ, obra citada).

Desta forma, a presente pesquisa, à medida que analisam os dados obtidos, busca responder ao problema proposto. Bogdan e Biklen (1994) afirmam a este respeito:

Não se trata de montar um quebra-cabeça cuja forma final conhecemos de antemão. Está-se a construir um quadro que vai ganhando forma à medida que se recolhem e examinam as partes. O processo de análise dos dados é como um funil: as coisas estão abertas de início (ou no topo) e vão-se tornando mais fechadas e específicas no extremo. (BOGDAN E BIKLEN, 1994, p. 50).

Lüdke e André (obra citada) esclarecem que os instrumentos de pesquisa mais adequados são: a entrevista, a análise documental e a observação. Enfoca, ainda, que a entrevista permite um aprofundamento dos dados obtidos; a análise documental e a observação, por sua vez, completam os dados obtidos na entrevista e enriquecem o seu conteúdo, confirmando ou não as afirmações e as alegações prestadas. Segundo elas, o pesquisador deve estar sempre atento à importância e à veracidade das informações que 
constrói durante sua pesquisa, por meio de sua inteligência, habilidade técnica e paixão, mas cercado de cuidados e atento às exigências que levem à confiança dos que necessitem de seus dados e resultados.

A entrevista, da forma que se processa nos meios de comunicação de massa, muitas vezes pode fornecer dados tendenciosos, se o entrevistador buscar pré determinar as respostas do entrevistado, para atender aos seus interesses. Para a pesquisa em educação, a entrevista pode ser de enorme valia e representa um dos instrumentos básicos para a coleta de dados, devendo para tanto, conhecer seus limites e respeitar suas exigências. A entrevista pode propiciar um ambiente harmonioso entre entrevistador e entrevistado, permitindo que sejam tratados diversos assuntos, dos mais simples aos mais complexos, possibilitando a imediata correção e esclarecimentos de dúvidas sem que o pesquisador se afaste do seu objetivo de pesquisa.

A entrevista pode ser estruturada, quando segue um roteiro previamente estruturado e visa à obtenção de dados uniformes; e não estruturada, quando não se tem um roteiro a ser seguido, fluindo naturalmente o diálogo. Entre essas duas extremidades de entrevista, existe a semiestruturada que se desenvolve por meio de um esquema básico, mas que não é seguido à risca, o que permite ao entrevistador fazer as correções que forem pertinentes para o objetivo de sua pesquisa (LÜDKE \& ANDRÉ, obra citada).

As pesquisas de cunho qualitativo exigem normalmente a realização de entrevistas, quase sempre longas e semiestruturadas. Nesses casos, a definição de critérios segundo os quais serão selecionados os sujeitos que vão compor o universo de investigação é um aspecto primordial, pois interfere diretamente na qualidade das informações, a partir das quais será possível construir a análise e chegar à compreensão mais ampla do problema delineado. A descrição e delimitação dos sujeitos a serem entrevistados, assim como o seu grau de representatividade no grupo social em estudo, constituem um ponto importante a ser observado, visto ser a base de grande parte do trabalho de campo a ser realizado (DUARTE, obra citada).

A observação, por sua vez, propicia um contato pessoal e próximo do pesquisador com o fenômeno pesquisado e permite a verificação de eventos e o ponto de vista dos sujeitos pesquisados, além da coleta de dados que outras metodologias de pesquisa não permitem. A história de vida e a bagagem cultural de cada pesquisador fazem com que cada um desses pesquisadores possa ter visões e opiniões diferentes sobre um mesmo fato e, dessa forma, para 
que a observação possa ter a confiabilidade de uma metodologia cientifica, faz-se necessário que esta seja controlada e sistematizada, por meio de um planejamento cuidadoso, definindose com antecedência "o que" e "o como" observar, após a delimitação do objeto de estudo, buscando sempre métodos rigorosos que validem suas observações. (LÜDKE \& ANDRÉ, obra citada).

A análise documental auxilia no complemento das informações já obtidas por outras técnicas e desvenda aspectos novos de um determinado tema. Qualquer material escrito pode ser utilizado como fonte de informação e de pesquisa, sendo este selecionado com o objetivo de que, com sua análise, possam ser fundamentadas afirmações e hipóteses do pesquisador (LÜDKE \& ANDRÉ, obra citada). Desta forma, seu objetivo é buscar informações nos documentos que deem credibilidade aos dados obtidos.

\subsection{Sujeitos da Pesquisa}

Os sujeitos de nossa pesquisa são quatro professores que trabalham na Escola de Aplicação da USP e lecionam disciplinas na área de ciências.

Quadro 1 - Caracterização dos Entrevistados

\begin{tabular}{|c|c|c|c|c|c|}
\hline Prof. & Formação & Disciplina que Leciona & $\begin{array}{l}\text { Tempo de } \\
\text { Formação }\end{array}$ & Sexo & $\begin{array}{c}\text { Tempo que } \\
\text { usa } \\
\text { computador }\end{array}$ \\
\hline $\mathbf{1}$ & $\begin{array}{l}\text { Licenciada em } \\
\text { Física e não } \\
\text { concluiu o } \\
\text { Mestrado. }\end{array}$ & $\begin{array}{l}\text { Ciências Escola de } \\
\text { Aplicação da USP. }\end{array}$ & 14 anos & Fem & 14 anos \\
\hline 2 & $\begin{array}{l}\text { Licenciado em } \\
\text { Física, é Mestre e } \\
\text { cursa Doutorado. }\end{array}$ & $\begin{array}{l}\text { Física e Ciências, } \\
\text { Escola de Aplicação da } \\
\text { USP. }\end{array}$ & 18 anos & Mas & 18 anos \\
\hline 3 & $\begin{array}{l}\text { Licenciada em } \\
\text { Química e é } \\
\text { Mestre. }\end{array}$ & $\begin{array}{l}\text { Biologia, Escola de } \\
\text { Aplicação da USP. }\end{array}$ & 22 anos & Fem & 22 anos \\
\hline 4 & $\begin{array}{l}\text { Licenciada em } \\
\text { Biologia, é Mestre } \\
\text { e cursa Doutorado. }\end{array}$ & $\begin{array}{l}\text { Biologia Escola de } \\
\text { Aplicação da USP. }\end{array}$ & 11 anos & Fem & 14 anos \\
\hline
\end{tabular}

A Escola de Aplicação da Faculdade de Educação da Universidade de São Paulo (EA-FEUSP) foi criada em 1959 e caracteriza-se pela busca da excelência educacional, procurando exercer o papel de centro de inovações e difusões de experiências pedagógicas. 
Nessa época, pertencia ao Centro Regional de Pesquisas Educacionais "Prof. Queiroz Filho", do Instituto Nacional de Estudos Pedagógicos (INEP), do Ministério da Educação e Cultura (MEC) e, em 1972, passou a pertencer à Universidade de São Paulo.

De acordo com seu Regimento Escolar (2006, p. 3 e 4), alguns de seus objetivos são:

I. Sediar e executar pesquisas de interesse próprio ou da Faculdade de Educação, de seus cursos e docentes, que visem ao aperfeiçoamento do processo educativo e de formação docente.

II. Oferecer oportunidades de estágio a alunos da Faculdade de Educação e a outras unidades da Universidade de São Paulo.

III. Oferecer subsídios à Faculdade de Educação da USP ou outras agências públicas de formação do educador.

IV. Divulgar experiências e contribuições resultantes de suas ações, prioritariamente para a rede pública de ensino.

V. Assegurar aos educandos a formação comum indispensável para o exercício da cidadania e o usufruto do trabalho oferecendo:

a. Segundo critérios estabelecidos neste Regimento para seleção de alunos, escolarização regular de ensino fundamental e médio a filhos e dependentes de professores e funcionários da Universidade de São Paulo;

b. Segundo critérios estabelecidos neste Regimento para seleção de alunos, vagas nos ensinos fundamental e médio para a comunidade externa à Universidade de São Paulo.

Os professores da Escola de Aplicação possuem uma carga horária que diferencia em poucos detalhes a jornada de um professor para o outro. Normalmente, durante a semana ele tem turno de 3 horas aula, de lh15min com cada turma que possui, totalizando 10 horas semanais. Além disso, possuem 2 horas por semana para plantão de dúvidas, 5 horas para preparação de aulas e correção de atividades, 8 horas de estudo individual e 7 horas de reuniões gerais e específicas por áreas.

Os professores da área de Ciências possuem sala ambiente, ou seja, cada um dos professores entrevistados tem sua própria sala de aula, que também é usado como laboratório, sendo que os alunos é que vão até a sala do professor e não o professor que vai até a sala de aula, como estamos acostumados a ver. Essas salas possuem carteiras para as atividades teóricas, além de bancadas com instrumentos para as aulas experimentais. Nessas salas, também existe um projetor que pode ser utilizado com laptops da própria escola ou do professor. 
Alunos e professores podem utilizar o Laboratório de Informática da Escola de Aplicação (LIEA) e cada aluno ainda recebeu um laptop do projeto UCA (Um Computador por Aluno) do Governo Federal. Trata-se de um projeto Educacional que tem por objetivo utilizar a tecnologia, a inclusão digital e o adensamento da cadeia produtiva comercial no Brasil e existe em aproximadamente 300 escolas estaduais e municipais em todo o país, que são selecionadas pelas Secretarias Estaduais e Municipais pelos estados e pela União Nacional dos Dirigentes Municipais de Educação (UNDIME). Cada escola recebeu um laptop para cada professor e aluno, infraestrutura para acesso à internet, além da capacitação de gestores e professores para o uso dessa tecnologia. No estado de São Paulo, existem sete escolas que participam desse projeto, sendo que na Escola de Aplicação da USP, o projeto este teve início em 10/11/2010, beneficiando 52 professores e 723 alunos (www.uca.gov.br).

O salário desses professores para uma carga semanal de 40 horas aula, é diferenciado se comparado com a de professores da rede pública estadual. Outro fato diferenciador é que as salas de aulas possuem uma população menor, numa proporção aproximada de menos de $50 \%$ de alunos, por um salário maior. O pagamento é feito pela Universidade de São Paulo e não diretamente pelo governo do Estado. Atualmente, os professores são contratados como funcionários da Universidade de São Paulo e não como professores de educação básica, ou seja, são contratados por um regime celetistas para trabalharem em uma autarquia. $\mathrm{O}$ diretor e o vice-diretor da escola são eleitos e a duração do mandato é de dois anos, podendo haver recondução, desde que sejam votados para isso.

Este contexto escolar foi primordial para nossa pesquisa, visto que se fosse realizada em outra escola que não possuísse esse perfil ficaria prejudicada. O fato de a Escola de Aplicação buscar a excelência educacional; ter como um dos objetivos sediar e executar pesquisas de interesse próprio ou da Faculdade de Educação; alunos e professores poderem utilizar o Laboratório de Informática; as salas ambientes possuírem projetor; ser disponibilizado um laptop para cada professor; trabalhar com o projeto UCA; além das outras características apontadas, são diferenciais importantes que incentivam e direcionam os professores a fazerem uso de Artefatos Computacionais no seu trabalho docente, condições essas que provavelmente não encontraríamos em outras escolas que não possuíssem esses aspectos educacionais. 


\subsection{Método de coleta de dados}

Inicialmente, realizamos entrevistas com quatro professores citados, de caráter semiestruturado, que foram utilizadas como instrumentos da pesquisa. Para tanto, tomamos como parâmetro o roteiro de entrevistas apresentado no Anexo 1, cujo objetivo foi o de realizar uma conversa informal com o professor, sendo o roteiro usado apenas como um norte, para que a entrevista não se afastasse de seus objetivos que eram: identificar se o computador auxilia o professor; se ele aprendeu ou aprende com sua utilização; como o computador ajuda a desenvolver melhor o trabalho docente; e se com ele o professor julga que ensina melhor. A conversa informal, a nosso ver, propicia uma fluidez e uma espontaneidade na fala do entrevistado, fornecendo assim muito mais informações relevantes para o objetivo pretendido, conforme esclarece Lüdke e André:

Será preferível e mesmo aconselhável o uso de um roteiro que guie a entrevista através de tópicos principais a serem cobertos. Esse roteiro seguirá naturalmente certa ordem lógica e também psicológica, isto é, cuidará para que haja uma sequência lógica entre os assuntos, dos mais simples aos mais complexos, respeitando o sentido do seu encadeamento. (LÜDKE e ANDRÉ, 1986, p.36)

A entrevista propicia a obtenção de informações sobre diversos temas, podendo fornecer dados relevantes para a pesquisa. Por meio do diálogo que se trava entre pesquisador e pesquisado, são levantadas questões pessoais que permitem aprofundar assuntos pertinentes à pesquisa, que não seriam possíveis de se explorar através de um simples questionário, que é um instrumento "frio" que não se permite o diálogo, havendo simplesmente respostas para determinadas perguntas. (LÜDKE \& ANDRÉ, obra citada).

Após essas entrevistas, decidimos acompanhar algumas aulas dos professores da Escola de Aplicação. Dessas aulas que acompanhamos, observamos que os professores de Física e Química, no primeiro bimestre do ano letivo de 2012, haviam desenvolvido em conjunto um Planejamento sobre o assunto "Radiações e Radioatividades", cujo objetivo era desenvolver suas aulas interdisciplinarmente com cada professor abordando o assunto pertinente a sua matéria, em relação a esse assunto selecionado, o que nos levou a focar nossas observações nesses dois professores.

A observação de algumas aulas constituiu-se como um instrumento secundário de pesquisa e foi importante para a compreensão do contexto do trabalho dos professores e dos dados coletados através da entrevista que foi o instrumento principal. Ao final das aulas foram ainda realizadas pequenas entrevistas, que foram transcritas para a coleta de novos dados, que 
tinham como objetivo identificar e verificar o porquê de determinados eventos ocorridos em sala de aula e o ponto de vista do professor sobre esses fatos. O preparo e planejamento eram verificados por meio da análise do material didático trazido pelo professor para a aula e também da observação durante a aula, para verificar se o professor se valia de algum artefato computacional para auxiliá-lo na aula.

\subsection{Organização dos dados para análise}

Após termos transcrito as quatro entrevistas iniciais e após a analise delas, sob o prisma da teoria de Tardif, criamos nossas categorias de pesquisa voltadas para o Saber Computacional e, a partir daí, recortamos dados das falas desses professores, que eram indicativos dos saberes que havíamos catalogado, conforme o Anexo 2. De posse dessas categorias e dos indicativos observados nas entrevistas citadas, tentamos relacioná-las com as observações de sala de aula e com as entrevistas feitas durante essas aulas, bem como com o Planejamento interdisciplinar dos professores de Física e Química sobre "Radiações e Radioatividades".

Tardif (2002) traz a personalização dos saberes, quando afirma que a docência tem como base pessoas que não se separam de suas histórias de vida, de suas experiências passada e de sua cultura. Esses saberes são produzidos e utilizados em função do trabalho do professor em que adquirem sentido, ou seja, os professores elaboram saberes nas articulações complexas do seu trabalho, nas interações e reflexões que estabelecem com seus pares, que ao serem compartilhados ganham significado. Dessa forma, não faz sentido falar no saber do professor se ele não estiver relacionado a situações e atividades em que esse saber é empregado.

Nesse contexto, esses dados nos levaram a tentar identificar o que nos interessa neste trabalho, que são os saberes elaborados pelos professores de Ciências, quando para a realização do seu trabalho, se utilizam dos Artefatos Computacionais como instrumento pedagógico que os auxiliam para melhor desenvolverem suas atividades, ou seja, o foco é verificar como o professor, pela experiência docente aprende a usar os Artefatos Computacionais no ensino, portanto como já proposto anteriormente, queremos responder a seguinte questão: “Que saberes docentes, relativos ao uso dos Artefatos Computacionais, são elaborados pelos professores a partir de sua utilização em sua prática docente”? 
Para a análise desse material de pesquisa, foi adotado o método de Análise de Conteúdo que consiste de um conjunto de instrumentos metodológicos para a análise das comunicações e, desta forma, vem sendo utilizado nas pesquisas qualitativas. Segundo Bardin, a análise de conteúdo apoia-se em:

Um conjunto de técnicas de análise das comunicações visando obter por procedimentos sistemáticos e objetivos de descrição do conteúdo das mensagens indicadores (qualitativos ou não) que permitam a inferência de conhecimentos relativos às condições de produção/recepção (variáveis inferidas) destas mensagens (BARDIN, 2010, p. 44).

Esse método tem como objetivo a análise da mensagem verbal (oral ou escrita), gestual, figurativa e documental; e expressa um significado e um sentido que não se caracteriza apenas pelo que foi expresso pelo indivíduo, mas também pelas diferentes e variadas representações que o sujeito tem de si. A mensagem expressa tem uma forte influência das condições históricas, econômicas e socioculturais de onde provém o indivíduo e, desta forma, a Análise de Conteúdo interpreta a linguagem, que foi construída a partir da sociedade onde o sujeito está inserido em um determinado momento histórico.

Segundo Bardin (2010), a Análise de Conteúdo se processa em três fases: a préanálise, a exploração do material e o tratamento dos resultados. A pré-análise é a fase de organização do estudo, sendo que todo o material é selecionado, lido, analisado e as hipóteses e os objetivos são reformulados surgindo indicadores que vão fundamentar a interpretação final. A fase de exploração do material é a análise propriamente dita, momento em que se efetua recortes e, por consequência, as categorizações em um movimento exploratório do material selecionado, transformando os dados brutos em informações que têm significado para o estudo proposto. Por fim, a fase do tratamento dos resultados propicia ao pesquisador inferir e realizar interpretações sobre os dados lapidados embasado na teoria apresentada, levando-o a dar sustentação ou não às hipóteses de pesquisa.

Esta técnica permite categorizar os diferentes elementos encontrados na comunicação do sujeito, seguindo um critério que vem ao encontro do objetivo pretendido. Ao categorizar e submeter um determinado material de comunicação a uma análise do conteúdo, o pesquisador pode obter dados que o levem a interpretar o seu objeto de pesquisa. O interesse não é o de descrever os conteúdos categorizados, mas sim deduzir, de maneira lógica, conhecimentos sobre o sujeito da comunicação. Fazendo-se uma analogia, ao analisarmos um cesto de lixo, podemos observar sobre as pessoas que o produziram, por 
exemplo: o nível socioeconômico, seus hábitos de consumo ou de desperdício entre outros aspectos. 


\section{Capítulo V - Análise dos dados}

\subsection{Categorias de pesquisa}

Após a realização das entrevistas, analisamos suas transcrições com o objetivo de identificar as categorizações dos saberes realizadas por Tardif (2002), ou seja, identificar os saberes da formação profissional, disciplinares, curriculares e experienciais, conforme descrito no Capítulo 3. A partir desse movimento, sem ter a intenção de idealizar um novo conceito de saber para o nosso trabalho, mas tendo como apoio as concepções de saber que eclodem das argumentações apresentadas pelos entrevistados, criamos nossas categorias e as definimos como sendo as dos Saberes Docentes Pedagógicos Computacionais (SDPC) de Formação Profissional, Disciplinar, Curriculares e Experienciais.

Em nossa conceituação, os Saberes Docentes Pedagógicos Computacionais (SDPC) são aqueles resultantes de reflexões sobre a prática educativa com o uso pedagógico de Artefatos Computacionais, reflexões estas racionais e que tendem para a formação de sistemas coerentes de representações e de orientação das atividades educativas. O SDPC é um saber plural, que pode ser formado pelos saberes computacionais da formação profissional, disciplinares, curriculares e experienciais, adquiridos com o uso pedagógico de Artefatos Computacionais. Este saber é essencialmente heterogêneo, visto que além da natureza dos saberes presentes, ele decorre também das relações entre o corpo docente, instituições de formação e alunos. Os SDPC de formação profissional, os curriculares e os disciplinares têm como origem os resultados das interações internas dos professores com o meio externo, já o

SDPC experiencial deriva do resultado das suas reflexões sobre seu trabalho, ou seja, é proveniente dos demais após serem retraduzidos e organizados por meio da prática e da experiência pedagógica com o uso de Artefatos Computacionais.

\subsubsection{SDPC de Formação Profissional}

Como já vimos, são aqueles apropriados pelos professores durante a sua formação inicial e continuada e caracterizam-se por terem origem nas disciplinas da Faculdade de Educação que relacionam o uso de Artefatos Computacionais com o ensino. Esses saberes são elaborados pela organização dos conteúdos de caráter pedagógicos veiculados por essas 
instituições de ensino, podendo também ser construídos durante a orientação de estágios nas disciplinas de caráter integrador das diversas áreas de conhecimento da formação docente, com destaque aos conhecimentos sobre os recursos tecnológicos como um meio didático. Assim, esses saberes são provenientes das reflexões sobre a utilização de Artefatos Computacionais no ensino.

Nas entrevistas não se verificou nenhum indício deste saber, mas foi possível observar que nesta fase de formação profissional houve de alguma forma, um primeiro contato destes professores com Artefatos Computacionais, que propiciou o início da sua utilização em sua vida pessoal e profissional.

- [...] enquanto aluna da graduação comecei a me envolver com o computador, até então eu nunca tinha tido um, e ele foi mais assim... para iniciar trabalhos na universidade... na minha formação em Física. Eu tinha alguns dados de laboratório, eu pegava estes dados com o computador, daí, depois o computador se tornou útil, na escrita de relatórios, que facilitava a formatação, em questão de fazer cópias, de fazer gráficos. Inicialmente a gente começou com o Excel, depois foi pra outros (...) (Professor 2)

- Os computadores estavam iniciando na Universidade de São Paulo e desde aquela época eu já comecei a trabalhar com bancos de dados, programação, desenvolvimento de projeto... (Professor 3)

- Na carreira profissional eu comecei a utilizar dentro da universidade, desenvolvendo programas para o Grupo de Pesquisas onde a gente trabalhava na especialização em Física Médica (Professor 3)

Provavelmente, estes saberes não tenham sido observados nas entrevistas visto que os cursos de formação frequentados por estes professores foram, conforme relatamos no Capítulo V - Quadro 1, aproximadamente há 14 anos atrás para o Professor 1; 18 anos atrás para o Professor 2; 22 anos atrás para o Professor 3; e 11 anos atrás para o Professor 4, ou seja, nessa época, o uso desses equipamentos não era tão difundido como o são atualmente. $\mathrm{O}$ professor 3, por exemplo, formou-se aproximadamente no ano de 1990 e, segundo seu próprio relato, “Os computadores estavam iniciando na Universidade de São Paulo”. O professor 2 por sua vez, formou-se aproximadamente no ano de 1992 e relata que "enquanto aluna da graduação comecei a me envolver com o computador”. Dessa forma, há indícios de que nessa época, o computador não estava significativamente presente no curso de formação profissional desses professores e, apesar de termos indícios da existência desse saber, o SDPC de Formação Profissional, não tivemos oportunidade de observá-lo. 


\subsubsection{SDPC Disciplinares}

São os saberes que têm como origem disciplinas ligadas à Ciências da Computação e suas implicações no ensino, que foram frequentadas por professores durante sua carreira profissional, tanto na formação inicial como na continuada e que tinham como objetivo dominar o uso de Artefatos Computacionais. Essas disciplinas são as que tinham como cerne em seu conteúdo as relações com o domínio dos recursos didáticos que os Artefatos Computacionais propiciam, e que foram classificados por nós no Capítulo II como sendo: Modelagem Computacional, Multimídia Computacional e a Internet. Na entrevista com os Professores 1, 2 e 3, encontramos relatos que, apesar de não serem argumentações que caracterizem um saber, demonstram que os entrevistados tiveram contato com disciplinas que tinham como objetivo o domínio dessa tecnologia.

Destacamos a seguir os relatos com esse caráter:

- Na Licenciatura de Física existia uma matéria chamada "Introdução à Computação" e aprendíamos a programar... foi assim que comecei a usar o computador... (Professor 1)

- O primeiro contato com o computador foi na graduação de Física que terminei em 94. Existia uma matéria de linguagem de programação na qual tínhamos que fazer uso do computador... (Professor 2)

- [...] na graduação já usava a programação de Pascal. No primeiro ano tive que aprender a programar Mac, não era um uso corriqueiro. Os relatórios entregavam a mão, usávamos mais para tratamentos de dados. (Professor 3)

Esses relatos nos levam a crer que provavelmente devido ao fator tempo decorrido da formação inicial desses professores, já apontados por nós neste capítulo, apesar de eles terem tido contato com disciplinas específicas para o uso do computador em sua formação inicial, elas não se referiam ao ensino e hoje não aparecem como sendo significativas nas suas práticas docentes atuais. Os entrevistados também não relataram terem tido contato, em sua formação continuada, com disciplinas com esse caráter. Esses fatos podem ter corroborado para a não identificação dos SDPC Disciplinares nas entrevistas e nas práticas desses professores.

\subsubsection{SDPC Curriculares}

Como já exposto, trata-se dos saberes adquiridos pelos professores durante a sua carreira profissional ao terem contato com determinados programas curriculares, programas 
de ensino e livros didáticos que têm como objetivo o uso de Artefatos Computacionais como meio didático. Devido a esse contato, os professores apropriam-se de determinados conhecimentos pedagógicos computacionais que os auxiliam em atividades docentes.

Na entrevista do Professor 1, constatamos o seguinte relato:

- (na escola onde lecionava) [...] tive contato com alguns softwares que davam conta de apresentar através de animações, alguns fenômenos que eram de ciências... $\mathrm{O}$ aluno conseguia visualizar... Ele podia fazer modificações, então, eu criei um roteiro para trabalhar com o software ... Era o de óptica geométrica (Professor 1)

No presente depoimento, não há argumentações que demonstrem a elaboração de um saber, trata-se apenas de um relato. O que verificamos é que a escola em tela disponibilizava alguns softwares para os professores usarem, que provavelmente devem ter sido fornecidos por órgãos da Secretaria da Educação e, dessa forma, deviam fazer parte de algum programa de distribuição de material didático. Os entrevistados não apontaram, em suas entrevistas ou nas práticas pedagógicas observadas, qualquer SDPC Curricular proveniente do contato que tiveram em sua carreira com programas curriculares, programas de ensino ou livros didáticos.

\subsubsection{SDPC Experienciais}

São aqueles elaborados pelos professores no seu dia-a-dia durante a realização de suas atividades profissionais com o uso de Artefatos Computacionais em aulas e da utilização que o docente faz dessa tecnologia para interagir com seus pares na busca de soluções e respostas para os problemas que surgem devido ao seu trabalho educativo.

Surgem motivados pela necessidade de enfrentar situações concretas que se apresentam no dia-a-dia, transitórias ou duradouras, que exigem dele improvisação e habilidades pessoais para a utilização desse recurso. O professor desenvolve estratégias para lidar com as situações que surgem, improvisando ou usando recursos que os Artefatos Computacionais oferecem para obter determinadas informações e formas de agir que o auxiliem na compreensão e solução de problemas de ensino.

O professor, quando conhecedor das possibilidades pedagógicas que os Artefatos Computacionais propiciam, reconhece na escola as dificuldades e obstáculos que se apresentam para a sua solução e, desta forma, procura introduzir essa tecnologia na escola, 
disponibilizando aos alunos atividades que a utilizem, incentivando o seu uso para que o seu objetivo pedagógico seja alcançado.

O quadro, a seguir, resume como a partir da base de construção das categorias de análise de Tardif (2002), construímos nossas categorias de análise.

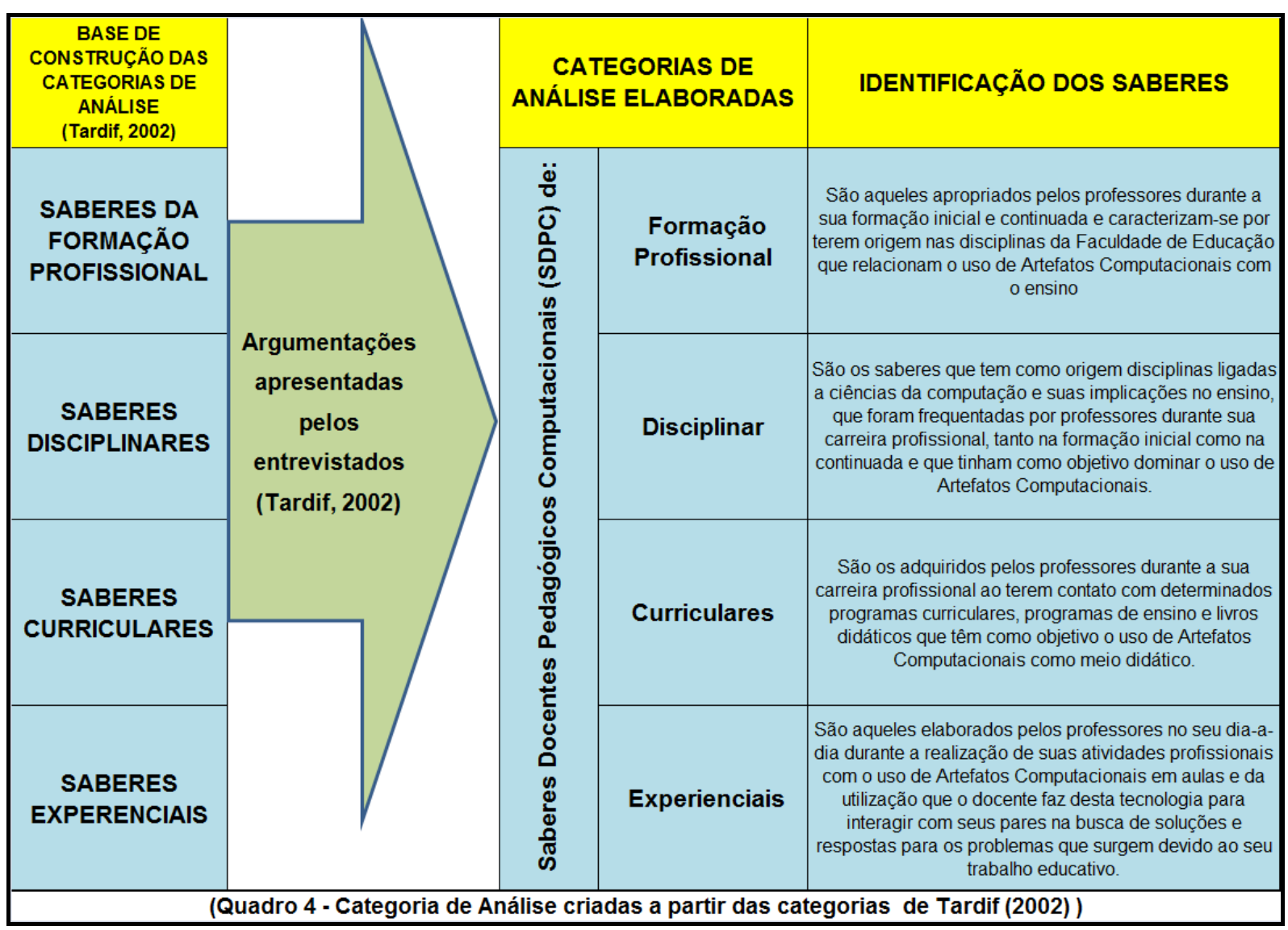

A presente pesquisa focou o trabalho docente e, por este motivo, as entrevistas exploraram práticas docentes com o uso pedagógico de Artefatos Computacionais. Além das entrevistas, foram realizadas observações de aulas e análise de materiais didáticos e do registro dos professores sobre o seu trabalho. Desta forma, nosso campo de observação focou a prática cotidiana dos professores, ou seja, tivemos oportunidade de observar as práticas pedagógicas provenientes das experiências adquiridas com o auxílio de Artefatos Computacionais, em que se constataram ações dos professores que corroboraram com as indicações apresentadas nas entrevistas. Por meio das quatro entrevistas e das observações realizadas, encontramos indicativos que nos levaram a subcategorizar os Saberes Docentes Pedagógicos Computacionais Experienciais (SDPC Exp) em: do Uso dos Recursos, da Comunicação, da Busca Digital e do Compartilhamento Digital. 
O Quadro 5, apresentado a seguir, exemplifica nossas categorias de análise criadas juntamente com as subcategorias dos SDPC Experienciais.

\section{SABERES DOCENTES PEDAGÓGICOS COMPUTACIONAIS (SDPC) de:}

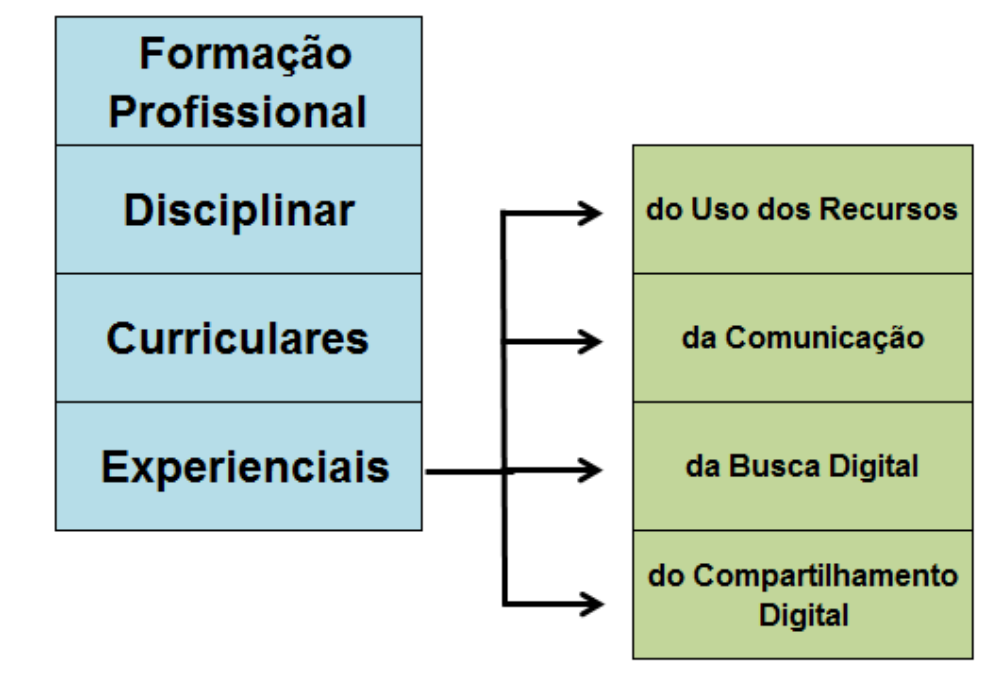

(Quadro 5 - Subcategorias dos SDPC Experienciais)

De acordo com a teoria de Tardif (2002), os grifos apresentados nos trechos das entrevistas que destacamos a seguir nos próximos tópicos referentes aos SDPC Experienciais, apontam os argumentos utilizados pelos professores pesquisados que justificam sua fala ou ações.

\subsection{SDPC Experienciais do Uso dos Recursos}

É o saber que se caracteriza pelo conhecimento que o professor desenvolve no dia-a-dia durante sua atividade docente sobre a utilização e o emprego dos recursos operacionais que o computador oferece e que o auxiliam a alcançar os objetivos pedagógicos de sua aula como, por exemplo, o uso do PowerPoint, Word, Excel, Paint, Media Player e outros. Este conhecimento vai se aprimorando com a prática e com a interação com os alunos, surgindo novas formas e métodos de utilização que facilitam alcançar o escopo pedagógico pretendido.

Nas entrevistas e observações de sala de aula, identificamos diversos saberes que se caracterizam como SDPC Experienciais do Uso dos Recursos, que passamos a apresentar: 
5.2.1 Saber que: "Os alunos apresentam graus bem diferenciados de familiaridade no uso dos recursos computacionais."

Os relatos a seguir justificam essa nossa categorização:

- [...] a gente tem dois tipos de alunos, na verdade três: aqueles alunos que têm muita empatia pelo computador, aqueles que têm muito medo do computador e aqueles alunos que tem o computador como uma coisa legal, que ele usa, mas para ele não é uma coisa essencial.... Por conta disso, é que eu trabalho com duplas, porque é assim, tem um aluno que sabe um pouco mais do que o outro e consegue mostrar para o seu parceiro como é que faz, e esse consegue fazer, com essas trocas os dois conseguem alcançar melhor o conhecimento (Professor1).

- Alguns alunos gostam e se identificam com o computador, gostam de trabalhar com ele, sabem manusear... Entendeu? Conhecem muita coisa de computação. Para esses alunos é fácil pegar o computador e pesquisar qualquer assunto, porque eles conhecem como se trabalha com a máquina. (Professor 1).

- As ferramentas são as mesmas, a diferença é que eles têm mais facilidades de baixar um vídeo, um arquivo, enfim, possuem mais facilidades. Coisas que tenho que fazer com um longo caminho, eles têm mais habilidades, ou seja, usam recursos diretos que o computador oferece e que por muitas vezes desconheco. (Professor. 4)

- Para mim, os alunos têm muito mais agilidade de lidar com os equipamentos, com os problemas que eles apresentam, com muito mais facilidade que nós, pois eles são de uma nova geração que tem um contato maior com os computadores do que a nossa, por isso aprendo muito com eles. (Professor 3).

- Então, tem alguns alunos que têm medo, você pede para ele escrever um texto no Word ele não sabe formatar, não sabe isso, não sabe aquilo, ou imprime o negócio com data e tudo. Então é assim, tem algumas coisas que o aluno ainda não desenvolveu habilidade para trabalhar, e ai ele fica temeroso com aquilo. (Professor 1).

Nos relatos acima apresentados, notamos que os professores demonstram que desenvolveram saberes em relação ao uso dos recursos computacionais no tocante que existem alunos que têm facilidades, às vezes até mais que o próprio professor, e outros nem tanto, que vão interferir em diferentes possibilidades para as ações em sala de aula.

Neste viés, reportando-nos às ideias de FREITAS (2009), destacamos que existe uma parte da população que tem pouco contato com Artefatos Computacionais, mas mesmo em comunidades carentes, existem alunos que têm acesso a essas tecnologias por diversos meios. Podemos facilmente observar que os jovens fazem uso de Artefatos Computacionais para acessar programas de redes sociais, onde se comunicam, publicam poesias, frases, pensamentos; divulgam fotos, vídeos, músicas e outros. Os alunos quando utilizam essa 
tecnologia, o fazem por meio de uma linguagem própria que facilita a digitação, mas que é de difícil compreensão para quem não a usa corriqueiramente. Estes alunos, segundo o autor supra citado, possuem um letramento o que foi definido como digital, que é diferente do conceito de letramento que usamos tradicionalmente, para nos comunicarmos, ou seja, é diferente do letramento que se usa ligado à aproximação e o contato com a cultura escrita.

Pelo exposto, observamos dois fatores: o primeiro, que nem todos têm acesso aos Artefatos Computacionais. O segundo fator é: os que possuem contato com esta tecnologia, o fazem com uma linguagem própria, diferente da linguagem adotada pedagogicamente e com a finalidade de acessar e divulgar conteúdos que não possuem fins didáticos. Desta forma, concluímos que esta diferença de grau de familiaridade com o uso de recursos computacionais que surgiu nos saberes dos professores, possa ser influenciada por esses fatores, e uma forma de driblar essa questão seria apresentando esses recursos computacionais aos alunos que têm pouco contato com esta tecnologia, e para os alunos que já a incorporaram ao seu dia-a-dia, canalizar este conhecimento que possuem para os fins pedagógicos, podendo aproveitar o letramento digital que eles já possuem para aumentar seus conhecimentos.

5.2.2 Saber que: “O uso dos recursos computacionais auxilia a aprendizagem dos alunos"

As falas, que a seguir elencamos, revelam esse saber:

- Quando fazemos seminários, apresentamos com cartazes, com maquetes ou com o PowerPoint, que entra como uma ferramenta ai, estes recursos ajudam o entendimento que ele tem, ou ajudam na produção de um texto que ele vai apresentar (Professor 1 ).

- Não uso sempre o PowerPoint. Nesta aula em particular, usei por dois motivos: para sintetizar os conceitos que estamos trabalhando, porque é melhor do que ficar escrevendo na lousa...; e porque nós tínhamos uma simulacão e este recurso permite apresentar de uma forma mais prática os espectros de alguns elementos químicos de emissão e absorção. (Professor 2 - Observações Sala de Aula).

- [...] os alunos ficam bem mais motivados em trabalhar com o computador do que com livros e revistas, mais até mesmo do que com atividade experimental... (Professor 1)

- [...] Porque não temos algo prático para ser o norte da atividade ... $\underline{\mathbf{O} \text { vídeo }}$ vai fazer uma abertura para comecarmos a discussão. (Professor 2 Prática sala de aula). 
- [...] é muito mais pobre sem visualização o aluno precisa imaginar mais, com a animação, os alunos conseguem visualizar melhor e compreender as diferencas. (Professor 4 - Prática sala de aula).

Os professores evidenciam este saber quando argumentam que o uso de Artefatos Computacionais ajuda no entendimento e na produção de textos; sintetiza os conceitos e permite produzir apresentações de uma forma mais prática, motivando os alunos, inclusive aqueles que ainda não desenvolveram habilidades de trabalhar com o computador. O uso dos recursos computacionais de vídeo e animações, por exemplo, facilitam a visualização que podem levar ao desenvolvimento e compreensão das aulas. A este respeito, os Professores 2 e 4 argumentaram que os professores, fazendo uso desta tecnologia, possuem algo prático para servir de norte para as atividades que pretendem desenvolver em sala de aula, que serve como modelo padrão. Alegam que sem a visualização, a explicação do professor fica muito filosófica, teórica e matemática, sendo que com a animação os alunos conseguem visualizar melhor e compreender as diferenças.

Neste sentido, podemos então classificar Artefatos Computacionais, conforme as concepções de mediação de Vygotsky, como um instrumento de mediação. Moran (2002), a este respeito, como já vimos anteriormente, esclarece que os Artefatos Computacionais propiciam: a pesquisa, a simulação, o teste de conhecimentos específicos, a produção de textos, a avaliação, a experiência e a descoberta de novos conceitos, lugares e ideias. Vasconcelos e outros (2003), por sua vez, defendem que a modelagem computacional possibilita simulações computacionais e uma análise diferenciada dos dados que contribui para o desenvolvimento cognitivo.

Desta forma, podemos verificar que os Artefatos Computacionais medeiam a ação didática do professor e o aprendizado dos alunos. Por meio dessa tecnologia, o professor pode realizar encontros virtuais com os alunos, motivando-os ainda a buscar, no vasto universo da internet, informações relevantes para o processo de ensino e aprendizagem.

5.2.3 Saber que: “A ação docente é importante para orientar e direcionar os alunos para buscar e selecionar conteúdos confiáveis na internet”"

Os alunos que sabem trabalhar com o computador têm facilidade em pesquisar e o professor precisa explicar a diferença entre sites confiáveis e não confiáveis. O relato abaixo especifica o presente saber: 
- Explicamos os endereços, as siglas, as informações confiáveis. Explicamos as diferenças entre sites confiáveis e os nãos confiáveis, o que é o Wikipedia, até que ponto é interessante, mostrando que qualquer um pode colocar informações lá e que podemos contribuir, mostrando toda a importância da navegação. (Professor 3).

A esse respeito, na obra supra citada, Moran declara que o professor possui o papel de orientador, conduzindo o aluno pela da internet, a fim de que eles desenvolvam trabalhos bem elaborados que podem ser divulgados e servir de fonte inspiradora para outros alunos. Mais uma vez, podemos verificar que os Artefatos Computacionais aparecem como um instrumento de mediação entre o professor e a aprendizagem, com destaque para a importância da função do professor neste processo, interagindo e orientando o aluno neste vasto universo que é a internet, que não poderia ser explorado sem o norteamento do professor.

5.2.4 Saber que: “Os recursos computacionais ampliam as possibilidades das ações didáticas".

Os relatos a seguir demonstram a elaboração de tal saber:

- Na minha prática pessoal facilitou bastante, você consegue se organizar melhor, você consegue ser mais sucinto, consegue adequar melhor o tempo.(Professor 2).

- O computador é uma ferramenta que amplia as possibilidades didáticas. Com o computador conectado à internet existem muito mais possibilidades do que sem ele, aumentando os recursos. Com isso, mais alunos conseguem entender no meio de uma coisa e outra. (Professor 4).

- Nas simulações, o aluno interage com as atividades, faz cálculos precisos dos experimentos, analisa o que ele viu na simulação com o real... $\underline{\mathbf{O}}$ computador pode dinamizar as minhas aulas substituindo a lousa... (Professor 2).

- Hoje eu não consigo ver minhas aulas sem o computador em sala de aula, se não tivesse eu teria que começar do zero, seria menos autônoma, ou seja, dependeria mais de materiais de outros profissionais, como livros didáticos, orientações, materiais do estudo. (Professor 4).

- [...] Agora para as demais aulas em geral, se não fosse de Laboratório de Investigação, mudaria talvez, porque teria que produzir um número maior de material de apoio impresso, eventualmente uma utilizacão maior da lousa com o giz... essa seria a grande diferenca. (professor 2).

- Como poderia visitar locais como a profundeza dos mares, onde eu não poderia estar indo, ele me propicia esta possibilidade. (Professor 1). 
- [...] me propicia mais tempo, pois para um professor, o tempo é uma coisa muito preciosa. Em segundos eu consigo buscar alguns materiais. Em livros didáticos, necessariamente não teria a mesma facilidade, pode ajudar os meus alunos, mas através do computador consigo adaptar os conteúdos para que fiquem de acordo com as necessidades de meus alunos, acrescentando ou tirando algumas coisas e aos poucos, vai ganhando a minha cara e nos anos seguintes vão sendo adaptados com o que já tenho, de acordo com a nova turma... (Professor 4).

- Você tem programas que o aluno pode mudar o peso de algumas coisas, mas não é a mesma coisa de você poder pegar, poder mexer, entendeu? É diferente de pegar o multímetro e poder ir medir a voltagem na sala do que ter isso representado no computador. Mas é interessante porque para crianças muito pequenas, você não vai dar um multímetro na mão porque não sabe onde ele vai colocar... (professor 1).

Nesses relatos, observamos que os professores pesquisados, com exceção do Professor 3, demonstraram a elaboração de saberes no sentido de que os recursos computacionais propiciam diversas possibilidades de uso, que podem facilitar a organizar, dinamizar e adequar o tempo das aulas, ampliando as possibilidades e substituindo outros recursos didáticos.

Na direção favorável a esse saber, argumentaram que os recursos computacionais propiciam possibilidades de conhecer locais que são inacessíveis para professores e alunos e também substituem determinados equipamentos utilizados em pesquisas, que poderiam ser perigosos para determinada faixa etária de alunos. Argumentam ainda que com estes recursos computacionais o professor consegue se organizar melhor, ser mais sucinto e adequar melhor o tempo, visto que os Artefatos Computacionais propiciam autonomia ao professor, na medida em que lhe dá velocidade de busca, podendo depender menos de materiais de outros profissionais, como livros didáticos, orientações, materiais oficiais etc. Além disso, evitam a produção de um número maior de material de apoio impresso, dinamizando as aulas e substituindo a lousa e outros recursos didáticos. Para o aluno, propicia ainda poder checar as questões que ele cria e testar as hipóteses que ele levanta, ampliando as possibilidades didáticas principalmente quando conectado à internet.

Cox (2003), sobre esse aspecto, escreveu que não há limites para o uso dos computadores no contexto escolar em simulações, jogos, comunicação, ensino a distância, softwares educativos, modelagem computacional e Internet. Vasconcelos e outros, em obra já citada, por sua vez, descrevem que a modelagem computacional possibilita uma análise diferenciada que contribui para o desenvolvimento cognitivo. VALENTE (1997) esclarece que a utilização de Artefatos Computacionais com fins pedagógicos exige uma capacitação 
técnica e uma prática reflexiva dos alunos e, neste sentido, esta tecnologia pode ser uma ferramenta importante na escola se houver uma formação profissional dos professores voltada para este fim.

Mais uma vez, percebemos que os Artefatos Computacionais são um importante instrumento de mediação entre professores e o aprendizado dos alunos, vindo ao encontro também das ideias de Freitas (2010), de que os Artefatos Computacionais podem ser considerados como uma Ferramenta Cultural que medeia a ação dos professores com a aprendizagem, propiciando a construção do conhecimento por meio da relação do professor com o aluno e sua aprendizagem, não de uma forma direta, mas sim mediada por este instrumento tecnológico.

\subsubsection{Saber que: “O uso pessoal do computador influencia o uso profissional.”}

A este respeito, destacamos o seguinte trecho da entrevista:

- Quando temos pouca intimidade com a tecnologia, fazemos pouco uso. Tem pessoas que tem intimidade zero com a tecnologia, principalmente as pessoas mais velhas as quais são resistentes. Quanto mais essa tecnologia esta incorporada no seu dia-a-dia, mais uso você vai fazer dela. Essa coisa do pessoal e do profissional acaba se encontrando. (Professor 3 ).

O Professor 3 demonstrou um saber voltado ao fato de que o educador que tem por hábito fazer uso pessoal do computador, também o tem em suas atividades profissionais. A este respeito, argumentou que quanto mais essa tecnologia está incorporada no dia-a-dia dos professores, mais uso ele faz dela no seu trabalho docente, sendo normal ele estar sempre conectado à internet, seja através do celular, do computador da escola, do computador de casa, do notebook, ou através de qualquer outro Artefato Computacional.

Essas ideias coadunam-se com a de Freitas (2010), que esclarece que os professores que são tímidos na utilização de Artefatos Computacionais não conseguem incluir essas tecnologias em suas práticas docentes diárias, ou seja, tanto professores como alunos que têm por hábito o uso de Artefatos Computacionais em suas atividades cotidianas possuem naturalmente uma melhor desenvoltura para lidar com essa tecnologia, como um recurso didático. Neste contexto, os professores possuem maior facilidade de utilizar os Artefatos Computacionais para alcançar objetivos pedagógicos e os alunos por sua vez, sobre a 
orientação destes professores, conseguem desenvolver as atividades propostas e chegar aos objetivos propostos.

5.2.6 Saber que: "Há alternativas para substituir e adequar o uso dos recursos computacionais em caso de panes digitais ou do não funcionamento adequado dos Artefatos Computacionais".

Na transcrição abaixo, observamos a manifestação do presente saber:

- É assim em sites extremamente confiáveis, por exemplo: da Nasa, eu estava pronta para mostrar uma coisa em um determinado dia, olhei estava tudo certo no dia anterior. Entrei no dia e você diz: nossa logo o site da Nasa esta fora do ar. Então são coisas que você acaba ficando na mão. Você tem que ter sempre um plano B. (Professor 1).

- Eu tenho que ter outras alternativas para minimizar os problemas com o computador embora ele facilite... (Professor 1).

O Professor 1 também demonstrou saber que é necessário possuir alternativas que possam adequar ou substituir o uso dos recursos computacionais, em caso de panes digitais ou do não funcionamento adequado dos Artefatos Computacionais. Neste sentido, argumentou que o professor tem de prever alternativas para minimizar esses problemas, pois se por algum motivo inesperado não tiver possibilidade de usar este recurso tecnológico, terá que ter previstas alternativas para que sua aula não seja prejudicada.

A aula com o uso de Artefatos Computacionais, ainda segundo Freitas (obra citada), não é reconhecida pelos professores como revolucionária na prática pedagógica e é vista apenas como mais um recurso tecnológico colocado à sua disposição. Este ponto de vista é o que observamos intrinsecamente neste relato do Professor 1, que demonstra de certa forma, que este recurso tecnológico não é tão importante para ele desenvolver suas práticas pedagógicas.

Novamente verificamos que os Artefatos Computacionais são colocados como sendo uma Ferramenta Cultural que medeia à ação dos professores e a aprendizagem. Os Artefatos Computacionais, apesar de não serem os únicos, constituem importante recurso didático, e possíveis problemas de funcionamento destes equipamentos podem ser previstos e as soluções podem ser antecipadas para que a aula não seja prejudicada. Fazendo uma analogia com o automóvel, o sujeito deixa de se locomover de carro, pois ele pode furar o pneu. É por este motivo que o próprio Código Nacional de Trânsito prevê que o estepe seja 
um dos itens de equipamentos de uso obrigatório no veículo, ou seja, o professor deve ter um posicionamento de que não vai usar Artefatos Computacionais em aula especifica, não porque este recurso possa apresentar defeitos ou dificuldades no seu uso, pois estes podem ser solucionados, mas sim, porque sua estratégia de aula exige que seja usado outro recurso didático.

\subsection{SDPC Experienciais da Comunicação}

É o saber que se distingue pelo do uso que o professor realiza do computador para se comunicar com alunos, professores ou outras pessoas relacionadas ao seu trabalho, com o objetivo de auxiliar em suas atividades docentes. Esta comunicação se dá através de e-mail, Facebook, Mensagens eletrônicas, Sky e outros. O saber se caracteriza pelo fato de o professor utilizar este recurso computacional para se comunicar e está convencido de que esse tipo de comunicação é importante para o seu trabalho docente. Nas entrevistas, identificamos os seguintes saberes compatíveis com essa categoria.

5.3.1 Saber que: "A comunicação pela internet é um meio de comunicação que facilita a interação entre professores e alunos na troca de informações, envio e compartilhamento de trabalhos".

As transcrições que destacamos a seguir nos remeteram a esta definição de saber:

- Eles podem me encaminhar trabalhos por email ... por etapas e a gente vai corrigindo, vai devolvendo para eles antes do trabalho final. Então, tanto por e-mail, como nas redes sociais, a gente troca informacão com o grupo de alunos dessa e de outras escolas. (Professor 2).

- (...) o email embora seja uma coisa normal, básica, hoje em dia é uma coisa muito importante, pois as informações chegam muito rápido, você abre o email já tem comunicado, e aqui como trabalhamos muito em grupo ajuda, pois se algum colega tem alguma dúvida, nós nos ajudamos e as repostas chegam muito rápido. O e-mail é uma ferramenta básica e facilita muito para a interação entre os professores e alunos para o funcionamento da escola. (Professor 3).

O Professor 2 e o Professor 3 apresentaram o saber de que a internet é um meio de comunicação que facilita a interação entre professores e alunos na troca de informações, envio e compartilhamento de trabalhos. Neste sentido, argumentaram que tanto por e-mail como nas redes sociais, o professor troca informações com o grupo de alunos de diferentes escolas, 
além de que as informações chegam muito rápidas. Argumentaram ainda que, por trabalharem muito em grupos, este recurso computacional possibilita esclarecer dúvidas individuais com respostas rápidas, alegando que o e-mail é uma ferramenta básica que facilita muito a interação entre professores e alunos para o funcionamento da escola.

Também Moran e outros (2000), a este respeito, esclareceram que a aprendizagem à distância pode se desenvolver por meio da interação de professores e alunos fora dos horários de aulas. Neste sentido, a internet é primordial para que a interação entre os sujeitos envolvidos na aprendizagem se estabeleça, mesmo estando eles distantes uns dos outros. A internet propicia interações entre pessoas que estão em locais distantes do planeta e o que vemos hoje, em muitas empresas, são reuniões, consultorias, treinamentos e outras inúmeras atividades ocorrendo por meio de encontros não presenciais proporcionados pela internet. As empresas recorrem a esses recursos com a finalidade de diminuir custos que implicam locomoção, tempo de viagem prejudicadas principalmente pelo trânsito e por atrasos de voos, estadia, alimentação entre outros. Essas estratégias podem também ser úteis no ensino e na aprendizagem.

\subsection{SDPC Experienciais da Busca}

Este saber é caracterizado pelo fato de o professor estar convencido de que o computador é uma fonte que facilita, tanto para ele como para o aluno, na pesquisa sobre assuntos e conteúdos pertinentes a seus objetivos pedagógicos. Essas pesquisas são realizadas em diversos sites que possuem conteúdo educacional ou não, mas que são realizadas com o intuito de os resultados serem utilizados para o desenvolvimento do seu trabalho docente. Assim, ao elaborar este saber, o professor tem consciência de que o computador propicia métodos de pesquisa sobre conteúdos e assuntos que facilitam, enriquecem e dinamizam o tempo em sua aula. Nas entrevistas, identificamos os saberes abaixo elencados:

5.4.1 Saber que: "Com o uso da internet, existem alunos que se dispersam dos assuntos pedagógicos e que não analisam as informações pesquisadas”.

A seguir destacamos relatos que explicam este saber: 
- [...] a gente tem sempre aquele aluno que sai do site que foi pedido para fazer coisas que não foram pedidas. Então ele vai entrar no msn dele.... porque o UCA, por exemplo, ele não está bloqueado para isso. (Professor 1).

- [...] o computador pode desviar a atencão daqueles alunos que vão olhar outro site, vão ver isso, aquilo... (Professor 1).

- [...] me entrega a página inteira, eu lhe faço uma pergunta e se ele não conseguir encontrar a resposta, é porque realmente ele não pesquisou, ele pegou a primeira página que apareceu aquele nome, colocou o seu e me entregou. (Professor 1).

O Professor 1, quanto à Busca Digital, demonstrou saber que os alunos, ao realizarem pesquisas na internet, podem se dispersar com assuntos que não tenham interesse pedagógico, bem como podem também apenas recortar e colar informações sem interpretálas. Fundamentou tal afirmação, utilizando a argumentação de que o computador pode desviar a atenção daqueles alunos que saem do site que foi pedido para acessar outros como, por exemplo, o msn. Justifica que para avaliar essa prática dos alunos, costuma fazer perguntas ao aluno sobre o assunto pesquisado e, se ele não conseguir encontrar a resposta, é porque realmente não pesquisou, apenas copiou a primeira página que apareceu com o nome da busca que realizou, colocou seu nome e entregou.

O que vemos são duas situações: uma em que o aluno durante a aula, fazendo uso de um Artefato Computacional, dispersa-se e começa a acessar outros sites de seu interesse, não relacionados à atividade que está sendo desenvolvida. Como exemplo, destacamos uma das aulas observadas do Professor 2. O aluno que estava mudando os slides da apresentação de PowerPoint, que o professor utilizava para nortear suas explicações, durante um intervalo entre um slide e outro, começou a acessar sua página pessoal do Facebook e que,por um descuido seu, foi exibido no telão e visto por todos, tornando-se motivo de risos na sala. Outra situação possível pode ocorrer quando o professor solicita que o aluno faça um trabalho sobre um determinado assunto e ele apenas pesquisa na internet sobre o assunto, copia e cola o que achou, imprime e entrega ao professor. É o caso que vemos nas declarações do Professor 1. Particularmente em nosso caso, já ocorreu uma situação em que o aluno não se deu ao trabalho de apagar o endereço do site que aparecia no rodapé da página do trabalho por ele impresso.

O professor, detentor de tal saber, deve procurar meios para que a atenção do aluno durante as aulas que usem como recurso didático Artefatos Computacionais, não se disperse e quando ele fizer consultas na internet ou em outras fontes, que seja realmente orientado a pesquisar, interpretar os dados encontrados e expressar sua opinião a respeito. 
Novamente nos valemos das ideias de Freitas (2010), de que os Artefatos Computacionais são um meio de mediação entre o professor e o aprendizado e, desta forma, é imprescindível a presença do professor que deve intervir e orientar o aluno para que essas duas situações apresentadas não ocorram.

5.4.2 Saber que: "A internet possui diversas fontes de informações que devem ser selecionadas visando ao objetivo pedagógico.”

- O computador demanda uma nova habilidade que é justamente essa, selecionar, pois você tem uma gama gigante de informações que aparece a sua frente muito rápida e você tem que saber lidar com isso, como lidar com informações tão rápidas, direcionando os alunos para sites confiáveis ... analisar, selecionar e sintetizar para depois produzir um documento meu. (Professor 3).

- Para buscar alguns conceitos específicos que me faltam, posso recorrer a internet que me oferece múltiplas fontes. (Professor 3).

- Às vezes, levamos os alunos às bibliotecas, mostramos o que tem, mas é difícil comparar, pois na biblioteca às vezes tem uma ou duas fontes enquanto na internet tem trinta ou muito mais a cada minuto, é muito maior a quantidade de informações. (Professor 3).

- [...] eles precisam saber usar as ferramentas como fonte de ajuda e ter um olhar crítico para as informacões que pegam da internet..., saber que eles podem receber informações importantes. (Professor 3).

- Tenho que trazer para a sala de aula, fazer com que eles acessem o portal do MEC e outros. Eles não chegam nisso sozinhos, tenho que deixar o endereco anotado para que eles possam entrar e estudar, eles têm que ser motivados pelo professor. (Professor 4).

- [...] sem o computador, daria apenas mais trabalho, perderia mais tempo, pois teria que ir à biblioteca, ou seja, perderia mais tempo... (Professor 3).

O Professor 3 e o Professor 4, quanto à busca digital, demonstraram saber que a internet possui diversas fontes de informações que podem ser acessadas rapidamente, poupando tempo nas buscas, mas que devem ser selecionadas visando ao objetivo pedagógico. A este respeito argumentaram que o professor necessita ter habilidades para lidar com as diversas informações disponíveis e acessíveis de forma rápida por meio da internet, sabendo analisar, selecionar e sintetizar essas informações para a produção de conhecimentos. Esclarecem que a internet oferece múltiplas fontes de informação para uma determinada pesquisa, enquanto a Biblioteca, por exemplo, oferece às vezes, apenas uma ou duas informações para a mesma busca. Argumentam ainda que o professor tem de orientar e 
motivar os alunos a acessar sites de interesse pedagógico, visto que os alunos necessitam usar o computador como uma fonte de ajuda e para tanto, precisam ter um olhar critico para as informações que existem na internet. Afirmam que a internet facilita as pesquisas, porque as informações estão "on line", e sem este recurso, as pesquisas seriam mais trabalhosas e se perderia mais tempo.

Como já discutimos anteriormente, a diversidade de informações disponíveis na internet não substitui a função do professor, visto que há a necessidade de os alunos serem orientados e direcionados de modo a buscar as informações relevantes que o auxiliem na construção do conhecimento sem se dispersarem neste universo de informações.

\subsection{SDPC Experienciais do Compartilhamento Digital}

O professor, por meio do uso pedagógico do computador, utiliza recursos computacionais, que propiciam a todos os seus alunos e/ou pares a possibilidade de compartilhar trabalhos e dados, com o intuito de que fiquem acessíveis a todos os envolvidos no processo de aprendizagem que está desenvolvendo. É o saber que o professor desenvolve no seu trabalho docente, quando utiliza recursos computacionais que armazenam trabalhos e dados em um ambiente virtual, disponibilizando-os para o acesso de todas as pessoas que estiverem participando desse processo de aprendizagem. Nas entrevistas, identificamos apenas o seguinte saber:

5.5.1 Saber: "Compartilhar arquivos que julgar de interesse para professores e alunos."

Este saber pode ser observado nos seguintes relatos:

- [...] a gente usa o Dropbox, então é assim, tem uma pasta que eu posso colocar, disponibilizar, por exemplo, para os meus alunos, eu posso colocar um texto lá e eles entrarem na minha pasta Dropbox, abrem é pegam o texto, que eu deixei disponibilizado para eles. (Professor 1)

- (Dropbox) É uma caixinha que você coloca nas nuvens. Na verdade quem administra é um professor por série. Você tem uma senha para poder acessar e postar, salvar dentro desse espaço conteúdos que podem ser acessados por todos.... nós professores, colocamos os documentos que acreditamos ser importantes: um artigo, uma experiência, enfim, o que o professor achar 
ser interessante e bacana, ele pode disponibilizar nesta pasta... (Professor 3)

- De qualquer lugar posso acessar, posso compartilhar os arquivos entre os professores e os alunos, às vezes correções de trabalhos interdisciplinares, disponibilizar alguns arquivos para os alunos. Esse recurso não tem custo, apenas um limite de arquivos de 3G. (Professor 4).

O Professore 1, o Professor 3 e o Professor 4 apresentaram saberes no sentido de que se deve compartilhar arquivos que possam ser de interesse para os pares e para os alunos no processo de ensino e aprendizagem. A esse respeito, afirmou que tal prática facilita o acesso pela internet dos arquivos disponíveis para professores e alunos.

Sobre esse aspecto, Moran (obra citada) esclarece que a Internet pode permitir um trabalho conjunto de professores e alunos na disponibilização de materiais didáticos, facilitando a interdisciplinaridade e podendo integrar toda a escola. O professor com esse recurso pode disponibilizar diversos tipos de materiais pedagógicos para seus alunos, e eles, por sua vez, ao terem acesso aos materiais, podem desenvolver suas atividades e disponibilizá-las para o professor que pode fazer suas observações e retornar ao aluno para revisão. Tudo isso virtualmente, cada um no seu espaço e no seu tempo, independente do tempo disponível presencialmente em sala.

O Quadro 6 resume e demonstra os saberes que se caracterizam como SDPC Experienciais:

\begin{tabular}{|c|c|}
\hline \multicolumn{2}{|r|}{ SABERES DOCENTES PEDAGÓGICOS COMPUTACIONAIS EXPERIENCIAIS } \\
\hline \multicolumn{2}{|r|}{ (5.2) SPDC EXPERIENCIAIS DO USO DOS RECURSOS } \\
\hline (5.2.1) & $\begin{array}{l}\text { "Os alunos apresentam graus bem diferenciados de familiaridade no uso dos } \\
\text { recursos computacionais." }\end{array}$ \\
\hline (5.2.2) & “O uso dos recursos computacionais auxilia a aprendizagem dos alunos" \\
\hline (5.2.3) & $\begin{array}{l}\text { "A ação doc } \\
\text { e selecionar }\end{array}$ \\
\hline (5.2.4) & “Os recursos computacionais ampliam as possibilidades das ações c \\
\hline$(\mathbf{5} .2 .5)$ & “O uso pessoal do computador influencia o \\
\hline (5.2.6) & $\begin{array}{l}\text { "Há alternativas para substituir e adequar o uso dos recursos computacionais, } \\
\text { em caso de panes digitais ou do não funcionamento adequado dos Artefatos } \\
\text { Computacionais." }\end{array}$ \\
\hline \multicolumn{2}{|r|}{ (5.3) SDPC EXPERIENCIAIS DA COMUNICAÇÃO } \\
\hline (5.3.1) & $\begin{array}{l}\text { "A comunicação pela internet é um meio de comunicação que facilita a } \\
\text { interação entre professores e alunos na troca de informações, envio e } \\
\text { compartilhamento de trabalhos". }\end{array}$ \\
\hline \multicolumn{2}{|r|}{ (5.4) SDPC Experienciais da Busca Digital } \\
\hline
\end{tabular}




\begin{tabular}{|c|c|}
\hline (5.4.1) & $\begin{array}{l}\text { "Com o uso da internet, existem alunos que se dispersam dos assuntos } \\
\text { pedagógicos e que não analisam as informações pesquisadas". }\end{array}$ \\
\hline $\begin{array}{r}\text { (5.4.2) } \\
\text { "A internet possui diversas fontes de informações que devem ser selecionadas } \\
\text { visando ao objetivo pedagógico." }\end{array}$ \\
\hline \\
\hline (5.5) SDPC Experienciais do Compartilhamento Digital \\
\hline
\end{tabular}

Os Saberes Docentes Pedagógicos Computacionais Experienciais, em suas subcategorias: do Uso dos Recursos, da Comunicação, da Busca Digital e do Compartilhamento Digital, identificados, categorizados e descritos por nós, mostram que os Artefatos Computacionais, de fato, estão sendo utilizados como instrumento de mediação na ação pedagógica dos professores como coloca Oliveira (2010). Pode-se afirmar que os Artefatos Computacionais são "elementos intermediários", numa relação que medeia a ação pedagógica do professor com a aprendizagem do aluno.

Esse fato está presente em todos os saberes que identificamos, mas nitidamente podemos notá-lo nos seguintes saberes: “o uso dos recursos computacionais auxilia a aprendizagem dos alunos”; “a ação docente é importante para orientar e direcionar os alunos para buscar e selecionar conteúdos confiáveis na internet”; “os recursos computacionais ampliam as possibilidades de ações didáticas”. Nesses saberes, vemos claramente que os Artefatos Computacionais são recursos didáticos de mediação utilizados pelos professores pesquisados que os auxiliam a alcançar seus objetivos pedagógicos.

Nossa opinião se alinha com as conclusões do trabalho de TÓFOLI (2003) no seguinte aspecto: primeiro, para que os Artefatos Computacionais estejam efetivamente presentes no processo de ensino e aprendizagem, o papel do professor é essencial. Os resultados deste autor indicaram que os professores, mesmo reconhecendo todas as facilidades que esta tecnologia propicia para o ensino, por medo e receio, não o usam efetivamente em suas atividades pedagógicas. Um segundo aspecto que destacamos é que a tática para incorporar esta tecnologia à Educação com objetivos pedagógicos deve iniciar-se pela formação inicial de professores e também deve estar presente nas formações continuadas. Um terceiro aspecto é que a função do professor não é apenas a de fornecer informações, mas sim, a de ser mediador das interações professor-aluno-computador, como descreveu esse autor, de maneira que o aluno possa ser autônomo para construir seu conhecimento. 


\section{Capítulo VI - Conclusões e considerações finais}

Como vimos, o objetivo deste trabalho foi o de investigar até que ponto a introdução de Artefatos Computacionais no trabalho docente pode auxiliar na elaboração de novos saberes pedagógicos, além de procurar mostrar a necessidade da introdução do computador nas escolas como uma ferramenta pedagógica de mediação entre o professor e a aprendizagem, conforme as concepções de mediação de Vygotsky que discutimos no Capítulo II. Outro ponto a observar é a formação profissional que, por ser marcante na vida do profissional, seria importante contar com a presença de Artefatos Computacionais como um recurso didático na formação de professores, o que poderia contribuir para a elaboração de saberes da formação profissional e disciplinar não se limitando apenas em desenvolver no professor, habilidades para o domínio desta tecnologia e sim efetivamente o seu uso pedagógico.

Nossa pesquisa pode ser uma contribuição inovadora que auxilia a sustentação teórica e metodológica, tanto das propostas de formação docente em desenvolvimento no ensino de Física e Ciências, como da prática realizada em sala de aula. Esta discussão nos remete a pensar em possíveis soluções que podem estar em parcerias entre escolas públicas e universidades, organizadas por meio de projetos colaborativos com propostas que, se bem estruturadas, com os papeis bem definidos para ambos os lados, pode trazer resultados significativos para difundir a utilização pedagógica dos Artefatos Computacionais.

Vários trabalhos apontam para a importância das disciplinas voltadas para o uso de Tecnologias Educacionais Informatizadas (TEI) em cursos de formação de professores, mas o que se vê é que essas disciplinas estão mais voltadas a formar professores numa perspectiva tradicionalista, sendo as tecnologias usadas em substituição à lousa, ao giz, ao retroprojetor e aos materiais impressos.

O nosso objetivo, como já dissemos na introdução, foi o de responder o problema: “Que saberes docentes, relativos ao uso dos Artefatos Computacionais, são elaborados pelos professores a partir de sua utilização em sua prática docente"? O uso do computador com seus diversos recursos didáticos pode auxiliar as práticas didáticas que podem ser sintetizados, a nosso ver, em: Modelagem Computacional, Multimídia Computacional e Internet. Podemos constatar que essas categorias satisfazem em grande parte as possibilidades em que o docente ou os discentes podem fazer uso dos Artefatos Computacionais, conforme 
verificamos nas entrevistas. Essas diversas formas de utilização do computador aparecem como possibilidades de diversificação de estratégias dos professores para desenvolverem seu trabalho, estratégias estas traduzidas nos Saberes Docentes Pedagógicos Computacionais (SDPC).

O resultado da análise dos dados revelou que a prática docente com o uso de Artefatos Computacionais contribui para a elaboração dos saberes que denominamos de SDPC Experienciais. Em nosso trabalho, como intuito de caracterizar diferenças dentro dessa grande categoria, definimos como subcategorias: do Uso dos Recursos, da Comunicação, da Busca Digital e do Compartilhamento Digital. Pudemos observar que esses saberes foram desenvolvidos e aprimorados pelos professores por meio de suas práticas pedagógicas do diaa-dia com o uso pedagógico de Artefatos Computacionais e com as interações com alunos e com os seus pares, interações estas principalmente com professores e com alunos que possuem afinidades com essa tecnologia.

Esses saberes podem ser primordiais para a prática pedagógica dos professores com o uso de Artefatos Computacionais, como um recurso didático. Os professores detentores do conjunto desses saberes podem elaborar e conduzir melhor suas aulas, usufruindo dos diversos recursos que esta tecnologia disponibiliza. Pode, ainda, comunicar-se de diversas formas, com distintas pessoas de lugares variados em tempo real, como se estivessem frente à frente com seus interlocutores. Outra possibilidade é possuir uma diversidade de fontes para pesquisa no mundo inteiro por meio da internet, sobre qualquer assunto, que pode contribuir para a construção do seu conhecimento e a de seus alunos e, ainda, podendo divulgar e compartilhar o seu trabalho e de seus alunos para quem tiver esse interesse.

Usando as concepções de Vygotsky sobre mediação, pudemos concluir que esta tecnologia pode sim ser considerada como ferramenta cultural com signos que medeiam a relação do professor com a aprendizagem dos alunos. Este papel de mediação dos Artefatos Computacionais ficou bastante evidente principalmente nos SDPC do Uso dos Recursos, no qual identificamos saberes que caracterizam que os recursos computacionais auxiliam a aprendizagem e ampliam as possibilidades didáticas como vimos nos seguintes depoimentos:

[...] estes recursos ajudam o entendimento que ele tem, ou ajudam na produção de um texto que ele vai apresentar (Professor 1).

[...] Com o computador conectado à internet existem muito mais possibilidades do que sem ele, aumentando os recursos. Com isso, mais alunos conseguem entender no meio de uma coisa e outra. (Professor 4). 
Além disso, cabe destacar também que a ação docente configurou-se, na visão dos professores, importante para orientar e direcionar os alunos para buscar e selecionar conteúdos confiáveis na internet, ou seja, verificamos que a ação do professor neste contexto é primordial para que os Artefatos Computacionais sejam usados como um instrumento que tem como finalidade facilita a aprendizagem, conforme ratifica a transcrição a seguir.

[...] Explicamos os endereços, as siglas, as informações confiáveis. Explicamos as diferenças entre sites confiáveis e os nãos confiáveis, o que é o Wikipedia, até que ponto é interessante, mostrando que qualquer um pode colocar informações lá e que podemos contribuir, mostrando toda a importância da navegação. (Professor 3).

O fato de termos realizado nossa pesquisa na Escola de Aplicação da USP foi importante para conseguirmos os resultados apresentados, principalmente devido à estrutura que esta instituição de ensino apresenta: com sala ambiente equipada com data show, sala de informática, organização que adota carga horária e salários diferenciados para os professores, desenvolvimentos de projetos para o uso de computadores pelos alunos (UCA), entre outros. Além disso, cabe destacar que os entrevistados são mestres, doutores ou estão cursando doutorado. Assim, se esta pesquisa tivesse sido desenvolvida em outro contexto, com outra realidade, os resultados não seriam os mesmos. Entretanto, devido ao tempo que os professores estão formados, não tiveram na sua formação inicial um uso efetivo dos Artefatos Computacionais. Este fato pode ter colaborado para não termos identificado os saberes que categorizamos de SDPC de Formação Profissional, Disciplinares e Curriculares. Apesar de o nosso foco de pesquisa estar alicerçado na prática, ou seja, nos saberes elaborados durante a realização de atividades pedagógicas profissionais, constatamos indícios de sua existência, levando em consideração a analogia que fizemos com as categorias apresentadas por TARDIF (2002).

Conforme apontado pelo autor quanto ao saberes, pudemos observar que os professores pesquisados utilizam em sua prática os Saberes Docentes Pedagógicos Computacionais por eles mesmos elaborados, com base em seus conhecimentos, vindos de diversas fontes e de sua própria atividade, que é estruturada, organizada e orientada para o uso dessa tecnologia. Assim, nossos resultados reforçam o enorme potencial da prática pedagógica com uso de Artefatos Computacionais para a elaboração de saberes.

Vivemos em um mundo muito influenciado por Artefatos Computacionais, onde grande parte da população vive dependente, por exemplo, de telefone celular e internet, serviços estes que quando são interrompidos causam grandes transtornos para as cidades. 
Essas tecnologias surgiram apenas há algumas décadas e não conseguimos imaginar viver mais sem elas.

As escolas por sua vez têm a necessidade de se adequar à evolução tecnológica, mas para haver mudanças na escola, tem de haver também mudanças nos professores, na sua formação e no seu desenvolvimento profissional, sendo eles concitados a colaborar. O que muitas vezes se vê, conforme apontado na pesquisa de Tófoli (2003), são professores que utilizam essa tecnologia em sua atividade docente, sem explorar o seu verdadeiro potencial e sem uma interação direta com os alunos de modo a levá-los a construir conhecimentos.

O papel do professor é primordial neste processo, visto que o computador por si só pode não se constituir como um recurso didático. Para tanto, é necessário o direcionamento do professor para conduzir o aluno neste vasto universo que os Artefatos Computacionais propiciam acessar. Sem a orientação do professor o aluno pode se dispersar e se embrenhar por caminhos totalmente diversos, sem cunho didático e com resultados totalmente alheios ao esperado, podendo inclusive ser prejudicial para o aluno em sua vida escolar e pessoal.

Nossa pesquisa apontou que os professores constroem saberes com a utilização de Artefatos Computacionais e que possuem o discernimento de que esta tecnologia propicia diversas facilidades para o ensino, conforme concluiu também o citado autor em sua pesquisa.

O sujeito principal no processo de ensino e aprendizagem é o professor, daí a necessidade de investimento no processo de sua formação inicial e continuada, para que se possibilite a adaptação dos professores e futuros professores para essa nova tendência cultural em tempos de inovações tecnológicas, com soluções que contribuam de forma eficiente para a integração da aprendizagem com os Artefatos Computacionais e todos os recursos presentes na contemporaneidade.

A formação inicial é um marco na identidade profissional e, por essa razão, é importante a presença de Artefatos Computacionais na formação de professores o que pode contribuir para a elaboração de SDPC de Formação Profissional, não se limitando apenas à criação de condições para que o professor domine o uso dessa tecnologia, mas fundamentando a importância da introdução da informática na educação como uma solução inovadora, com novas abordagens que sejam fundamentadas, de forma ampla e profunda, nos cursos de formação. A formação do professor deve proporcionar condições para que ele desenvolva saberes sobre as técnicas computacionais e de como integrar o computador à sua prática 
pedagógica, criando condições para que ele saiba aplicar o aprendizado e as experiências vividas durante a sua formação na sua realidade de sala de aula, conforme as necessidades de seus alunos e os objetivos pedagógicos que se dispõe a atingir.

Assim, finalizamos nosso trabalho, com a certeza de que não pararemos por aqui, pois as respostas obtidas ao nosso problema de pesquisa nos geram novas dúvidas, instigandonos a continuar perguntando e a continuar buscando respostas. Perguntas como: “Os alunos que usam cotidianamente os Artefatos Computacionais possuem dificuldades para o seu uso com fins pedagógicos?” E com relação aos professores: “Que Saberes Docentes Pedagógicos Computacionais (SDPC) de Formação Profissional os professores desenvolvem nos cursos de formação de professores?”, entre outros questionamentos.

Os Artefatos Computacionais estão em constante aprimoramento e evolução, o que leva à necessidade de continuadas especializações no uso pedagógico desta tecnologia, principalmente nos cursos de formação continuada, sobretudo para aqueles professores que não tiveram a oportunidade de ter esse contato em seu curso de formação profissional inicial. Este é um ponto que pode ser abordado nos cursos de formação de professores e retomado em outras pesquisas. 


\section{VII - Referências Bibliográficas}

ABIB, M. L. V. S. A construção de conhecimentos sobre ensino na formação inicial do professor de Física: agora, nós já temos as perguntas. São Paulo: Tese de Doutorado. Faculdade de Educação da Universidade de São Paulo, 1997.

ALVES, A.J. O Planejamento de Pesquisas Qualitativas em Educação. São Paulo: Caderno de Pesquisa (77): 53-61, 1991

ARANTES, A. R.; GARCIA, D.; STUDART, N. Estudo exploratório sobre as concepções dos professores de Física acerca dos objetos educacionais digitais. São Carlos: Universidade Federal de São Carlos/Programa de Pós Graduação em Ensino de Ciências Exatas, 2011.

ARAÚJO, R. S.; BARROS, S. de S.; LOPES, A. M. de A. ¿Como usar software de simulación em clases de Física? Florianópolis: Caderno Catarinense de Ensino de Física. v. 17, n. 1, p. 50-66, abr. 2000.

AZEVEDO, M.N. Pesquisa-Ação e Atividades Investigativas na Aprendizagem da Docência em Ciências. São Paulo: Dissertação - Mestrado Faculdade de Educação da Universidade de São Paulo, 2008.

BARDIN, L. Análise de Conteúdo. Lisboa: Edições 70, 2010.

BETTIO, R. W.; MARTINS, A. Objetos de aprendizado: um novo modelo direcionado ao ensino a distância. 2004. Disponível em:

BOGDAN, R, C.; BIKLEN, S. K. Investigação qualitativa em educação: uma introdução a teoria e aos métodos. Porto: Porto Editora, 1994, 335p.

BORUCHOVITCH, E.; BZUNECK, J.A. (orgs). A Motivação do Aluno. Petrópolis: Vozes, 2001.

BRASIL. Resolução CNE/CP 1/2002. Diretrizes Curriculares Nacionais para a Formação de Professores da Educação Básica. Disponível em: http://portal.mec.gov.br/seesp/arquivos/pdf/res1_2.pdf. Acessado em: 23 mar. 2007. 
CACHAPUZ, A.; GIL-PÉREZ, D.; CARVALHO, A.M.P.; PRAIA, J.; VILCHES, A. (orgs). A Necessária Renovação do Ensino das Ciências. São Paulo: Cortez , 2005.

COUTINHO, C. P. Tecnologias Web 2.0 na sala de aula: três propostas de futuros professores de Português. In: Educação, Formação \& Tecnologias, vol. 2 (1), Maio 2009. Disponível em: http://eft.educom.pt/index.php/eft/article/viewFile/46/54. Acesso em: 11, Jan, 2011.

COX, K. K. Informática na Educação Escolar. Campinas: Autores Associados, 2003. 124 p. (selecionamos algumas de uso do computador, tais como: a simulação, os jogos, a comunicação, o ensino à distância, os programas comerciais e os programas ou softwares, modelagem computacional e Internet.)

CUNEGATTI, C.M.S. As novas tecnologias da educação colocam desafios outros à escola. Ijuí: Revista Educação nas Ciências, 2004.

FIOLHAIS, C., TRINDADE, J. Física no Computador: O computador como uma ferramenta no ensino e na aprendizagem das ciências Físicas. Revista Brasileira de Ensino de Física, São Paulo: 2003.

FOUREZ, G. Crise no Ensino de Ciências. Investigações em Ensino de Ciências. São Paulo: V8(2), pp. 109-123, 2003.

FREITAS, H. A.; ABIB, M. L. V. S. Motivação do aluno e o uso do computador em aulas de Física. Curitiba: EPEF XI, 2008.

FREITAS, M. T. A. (org.). Cibercultura e Formação de Professore. Belo Horizonte: Autêntica Editora, 2009.

GALINDO, M. A. Melhoria do Ensino de Ciências nas Séries Iniciais do Ensino Fundamental: Contribuições e Limites de um Projeto Colaborativo. São Paulo Dissertação - Mestrado Faculdade de Educação da Universidade de São Paulo, 2007.

GERALDI, Corinta M. G. (org.). Refletindo com Zeichner: um encontro orientado por preocupações políticas, teóricas e epistemológicas. Campinas: Cartografias do trabalho docente: professor(a)-pesquisador(a) Mercado de Letras, 1998.

GIORDAN, M. Computadores e Linguagens nas Aulas de Ciências. Ijuí: Ed. Unijuí, 2008. 
http://www.universia.com.br/materia/materia.jsp?id=5938. Acesso em: 20 maio 2006.

KLAJN, S. Física: a Vilã da Escola. Passo Fundo: Editora UPF, 2002.

LUDKE, M.; ANDRÉ, M. Pesquisa em Educação: Abordagens Qualitativas. São Paulo: EPU, 1986.

MARTINS, S.; TAKAHASHI, E.; LIMA, S.; CARVALHO, D.; MENDES, E.; GARGIULO, V. Tecnologias computacionais aplicadas à aprendizagem cooperativa em Física. Curitiba: EPEF XI, 2008.

MIZUKAMI, M. G. N. ; REALI, A. M. M. R. (Orgs.). Formação de Professores, Práticas Pedagógicas e Escola. São Carlos: Ed. São Carlos, 2002.

MIZUKAMI, M. G. N. Ensino as Abordagens do Processo. São Paulo: EPU, 2000.

MOnTEIRO, M. A. A.; GERMAnO, J. S. E.; MONTEIRO, I. C. C. A utilização de recursos multimídia em aulas de Física a partir do referencial teórico de Vigotski. Curitiba: EPEF XI, 2008.

MORAN, J. M., MASETTO, M. T. e BEHRENS, M. A. Novas Tecnologias e Mediação Pedagógica. Campinas, SP, Papirus, 2000.

NUNES, E. R. Ensino de Conceitos Físicos no Ensino Médio e as Contribuições dos Objetos de Aprendizagem. São Paulo. Tese - Doutorado Faculdade de Educação da Universidade de São Paulo, 2011.

OLIVEIRA, M. K. de. Vygotsky: Aprendizado e Desenvolvimento um Processo SócioHistórico. São Paulo: Editora Scipione, 2010.

PONTE, J. P. Tecnologias de Informação e Comunicação na formação de professores: Que desafios? Lisboa: Revista Ibero Americana, Setembro - Dezembro 2000.

SIlva, J. C. G.; CARVAlhO, A. M. P.; CHAVES, J. D. A.C. Uma simulação de computador como ferramenta de enculturação cientifica. Curitiba: EPEF XI, 2008.

TARDIF, M. Saberes Docentes e Formação Profissional. Petrópolis: Editora Vozes, 2002.

TÓFOLI, M. R. Utilização e Compreensão do Computador: Um Olhar no dia-a-dia do Professor. São Paulo: Dissertação - Mestrado Faculdade de Educação da Universidade de São Paulo, 2003. 
VALENTE, J. A. Visão analítica da Informática na Educação no Brasil: a questão da formação do professor. Revista Brasileira de Informática na Educação. Porto Alegre: Sociedade Brasileira de Computação, no 1, set. de 1997.

VASCONCELOS, F. H. L., SANATANA, J. R., NETO, H. B. Aprendizagem mediada por computador: uma experiência de ensino de Física com a utilização da simulação computacional. Fortaleza: XVI Simpósio nacional de ensino de Física, 2003.

VYGOTSKY, L. S. A Construção do Pensamento e da Linguagem. São Paulo: Ed. Martins Fonte, 2001.

WILEY, David A. The instructional use of learning objects. Versão on line Disponível em http://reusability,org/read/, Acesso em 20 fevereiro 2007. 


\section{VIII - Bibliografia Consultada}

ABIB, M. L. V. S. A contribuição da Prática de Ensino para a formação inicial de professores de Física. In: Rosa, E. G. Dalva; Souza, C. de Vanildo (orgs.). Didática e práticas de ensino: interfaces com diferentes saberes e lugares formativos. Rio de Janeiro: DP\&A, 2002.

ABIB, M. L. V. S. Formação de Professores de Ciências: Treinamento ou Cooperação? In: MATOS, Cauê. (Org.). Conhecimento Científico e Vida Cotidiana. São Paulo: Ed. Terceira Margem. 2003, p. 87-101, 2003.

AMORIM, C.C. Compartilhando e Construindo: Ação Mediada entre Crianças e Adolescentes no desenvolvimento de Blog Pedagógico-Literário em uma Biblioteca da Cidade de São Paulo. São Paulo: USP, 2008. Dissertação. Programa de Pós-Graduação em Educação, Faculdade de Filosofia, Letras e Ciências Humanas, Universidade de São Paulo, 2008.

BELLONI, M.L. O que é mídia-educação. Campinas: Autores Associados, 2001.

BIANCHETTI, L.; FERREIRA, S. de L. As tecnologias de informação e de comunicação e as possibilidades de interatividade para a educação. In: PRETTO, N. de L. (Org.). Tecnologia e novas educações. Salvador: EDUFBA, 2005. p. 151-165.

BLOGGER homepage São Francisco, CA: Pyra Labs, 2003. Disponível em $<$ http://www.blogger.com/>. Acesso em 10 janeiro 2011.

BOTTENTUIT JUNIOR, J. B.; COUTINHO, C. P. Podcast uma Ferramenta Tecnológica para auxílio ao Ensino de Deficientes Visuais. In: VIII LUSOCOM: Comunicação, Espaço Global e Lusofonia. Lisboa: Universidade Lusófona de Humanidades e Tecnologias, p.21142126, 2009. Disponível em:

CAPECCHI, M. C. V. M. Aspectos da cultura científica em atividades de experimentação nas aulas de Física. 2004. Tese (Doutorado em Educação) - Faculdade de Educação, Universidade de São Paulo, São Paulo, 2004.

CARMO, A.B. Construindo a linguagem gráfica em uma aula experimental de Física. In: Ciência e Educação, v.15, n.1, 2009. 
CARVALHO, A. M. P. ; GIL-PEREZ, D. Formação de professores de Ciências. São Paulo: Cortez, 1998.

CARVAlHO, A. M. P.; BARROS, M. A.; GONÇALVES, M. E. R.; REY, R. C.; VANUCCHI, A. I. Ciências no Ensino Fundamental: o conhecimento físico. São Paulo: Scipione, 1998.

CARVALHO, A. M. P. Enseñar física y fomentar una enculturación científica. Alambique - Didáctica de las Ciencias Experimentales, n.51, p. 66-75, 2007.

As Pesquisas em Ensino de Ciências e suas Influências na Formação Docente. São Paulo: FEUSP, 2000.

.Em busca de uma nova formação de professores. In: Formação de Professores de Ciências, 1996.

. Enculturação Científica: uma meta do ensino de Ciências. In: atas do XIV ENDIPE, 2009.

. Orientações Curriculares Tecnologias de Informação e Comunicação PROPOSIÇÕES DE EXPECTATIVAS DE APRENDIZAGEM. São Paulo: Secretaria Municipal de Educação - São Paulo : SME / DOT, 2010.

CONTRERAS, R. A autonomia dos professores. Ed. Vozes, 2002.

COUTINHO, C. P.; BOTTENTUIT JUNIOR, J. B. Blog e Wiki. Os Futuros Professores e as Ferramentas da Web 2.0. In: SIIE'2007 - 14 - 16 Nov. 2007. Disponível em: http://repositorium.sdum.uminho.pt/bitstream/1822/7358/1/Com\%2520SIIE.pdf. Acesso em: 11, Jan, 2011.

COUTO, E.; FONSECA, D. Comunidades virtuais: herança cultural e tendência contemporânea. In: PRETTO, N. de L. (Org.). Tecnologia e novas educações. Salvador: EDUFBA, 2005, p. 53-81.

CUNHA, M.I. O Bom Professor e sua Prática. Campinas: Papirus, 2005.

DINIZ-PEREIRA, J. E.; ZEICHNER, K. M. (Orgs.). A pesquisa na formação e no trabalho docente. Belo Horizonte: Autêntica Editora, 2002. 
DUARTE, R. Pesquisa Qualitativa: Reflexões sobre o Trabalho de Campo. Rio de Janeiro: Cadernos de Pesquisa - SciELO Brasil, 2002.

FERRACIOLI, L. Tecnologia no Ensino de Física: Uma revisão dos IX e X Encontros de Pesquisa em Ensino de Física. São Luís: XVII Simpósio Nacional de Ensino de Física, 2007.

FERREIRA, S. de L. A Internet como espaço de construção de conhecimento. In: ALVES, L.; NOVA, C. (Orgs.). Educação e Tecnologia. Salvador: Editora da UNEB, 2003.

FOUREZ, G.; Crise no Ensino de Ciências. Dept “Sciences, Philosophies, Sociétés”, 2004.

FREIRE, P. Pedagogia da Autonomia. São Paulo: Ed. Vozes, 2006.

GIL-PÉREZ, D.; ABIB, M. L. V. S.; EDWARDS, M.; VILCHES, A. (2000). Las concepciones de los profesores ciencias brasileños sobre la situación del mundo. Investigações em Ensino de Ciências. 5(3).

GUTIERREZ, S. Mapeando caminhos de autoria e autonomia: a inserção das tecnologias educacionais informatizadas no trabalho de professores que cooperam em comunidades de pesquisadores. Porto Alegre: UFRGS, 2004. Dissertação. Programa de Pós-Graduação em Educação, Faculdade de Educação, Universidade Federal do Rio Grande do Sul, Porto Alegre, 2004.

Weblogs e Educação: contribuição para a construção de uma teoria. Porto Alegre: CINTED-UFRGS Novas Tecnologias da Educação, V.3 nº 1, 2005. Disponível em:

http://www.virtual.ufc.br/cursouca/modulo_web2/parada01_cid2/para_saber_mais/gutierrezte oriaweblogs.pdf. Acesso em: 10, Jan, 2011.

HARRES, J.B.S. Investigações em Ensino de Ciência. Porto Alegre: Instituto de Física Universidade Federal do Rio Grande do Sul, 1999.

HEIDE, A. e STILBORNE, L. Guia do professor para a Internet. 2 ed. Porto Alegre: Artes Médicas, 2000.

http://repositorium.sdum.uminho.pt/bitstream/1822/9030/1/Podcast\%20-\%20Lusocom.pdf. Acesso em: 05, Jan, 2011. 
JORDÃO, R. S. Tutoria e Pesquisa-Ação no estágio Supervisionado: Contribuições para a Formação de Professores de Biologia. São Paulo: Tese - Doutorado Faculdade de Educação da Universidade de São Paulo, 2005.

LÉVY, Pierre. As tecnologias da inteligência: o futuro do pensamento na era da informática. Rio de Janeiro: Ed. 34, 1993.

MERCADO,L.P.L., A Internet como Ambiente Auxiliar do Professor no Processo Ensino-Aprendizagem. Maceió: EDUFAL, 2001.

MIDGLEY, C., KAPLAN, A., MIDDLETON, M., and MAEHR, M. University of Michigan,URDAN, T., Santa Clara University, ANDERMAN, L.H., University of Missouri, Kansas City, ANDERMAN, E., University of Kentucky, and ROESER, R., Stanford University. The Development and Validation of Scales Assessing Students' Achievement Goal Orientations. Contemporary Educational Psychology 23, 113-131 (1998) Article nº. EP980965.

NASCIMENTO, G. O professor e as tecnologias intelectuais: uma parceria que pode dar certo. In: ALVES, L. R. S.; SILVA, J. B. (Orgs.). Educação e Cibercultura. Salvador: EDUFBA, 2001.

NERI, M. C. e outros. Mapa da Inclusão Digital. Rio de Janeiro: FGV, CPS, 2012.

PIMENTA, Selma G. Professor reflexivo: construindo uma crítica. In: Pimenta \& Ghedin (orgs) Professor reflexivo no Brasil: gênese e crítica do conceito. São Paulo: Cortez. 2002.

PORCIÚNCULA, E.F.S. As novas tecnologias sob a ótica dos agentes da educação. Ijuí: Educação nas Ciências Unijuí, 2004.

PÓRLAN ARIZA, R., RIVERO GARCIA, A. MARTIN DEL POZO, R. Conocimiento professional y epistemologia de los profesores l: teoria, métodos e instrumentos. Enseñanza de las ciencias, 15 (2),155-171, 1997.

PÓRLAN ARIZA, R., RIVERO GARCIA, A. MARTIN DEL POZO, R. Conocimiento professional y epistemologia de los profesores 11: estudios empiricos e conclusiones. Enseñanza de las ciencias, 16 (2),271-288, 1998. 
PORTAL DA SECRETÁRIA MUNICIPAL DE EDUCAÇÃO DE SÃO PAULO. Disponível em: http://portalsme.prefeitura.sp.gov.br/Projetos/ie/Default.aspx?MenuID=19, consultado 04/02/2011.

PRETTO, N. de L. Uma Escola sem/com futuro. 3. ed. Campinas: Papirus, 2001. 246 p.

RABÊLLO, M. E. D. L. Centro de Referência Integral de Adolescente (CRIA) / Sede do MIAC Rua Gregório de Matos no 21 Pelourinho CEP 40025-060 Disponível: http://www.cedeca.org.br/PDF/protagonismo_juvenil_eleonora_rabello.pdf, consultado 04/02/2011.

ROCKWELL, E. La Experiencia Etnográfica: Historia y Cultura em los Processos Educativos. Buenos Aires: Paidós, 2009.

TENÓRIO, R. M. Cérebros e Computadores: a complementaridade analógico digital na informática e na educação. 4. ed. São Paulo: Escrituras Editora, 2003, 212 p.

VASCONCELOS, F.H.L., CARVALHO, R.O., ROMEU,M.C., SANATANA, J.R., NETO,H.B. A utilização de software educativo aplicado ao ensino de Física com o uso da modelagem. Fortaleza: CE, XVI Simpósio nacional de ensino de Física - UFC Artigo, 2003.

VEIT, E.A. Modelagem computacional no Ensino de Física. Porto Alegre: Instituto de Física, UFRGS, XVI SNEF, 2005.

VYGOTSKY, L. S. A Formação Social da Mente. São Paulo: Ed. Martins Fonte, 1991.

WERTSCH, J.V., Mind as Actio. New York: Oxford Univ. Press, 1998. 


\section{ANEXO 1 - ROTEIRO DE ENTREVISTA}

PROBLEMA DE PESQUISA

"Que saberes docentes, relativos ao uso dos Artefatos Computacionais, são elaborados pelos professores a partir de sua utilização em sua prática docente”?

Objetivo: O computador: Auxilia o professor? O que ele aprendeu/aprende com sua utilização? Como ajuda a desenvolver melhor o trabalho docente? Ensina Melhor?

\section{FOCO 1 - QUEM É O PROFESSOR? - Perfil do professor}

1. Qual sua formação pedagógica?

2. Em que ano saiu da Universidade? (término da graduação)

3. Fez ou faz algum curso de formação continuada e/ou pós-graduação? Quais? Quando?

FOCO 2 - INTRODUÇÃO DO COMPUTADOR NA VIDA DO PROFESSOR, PESSOAL E PROFISSIONAL.

4. Você tem computador pessoal (PC)? Qual? (Caso negativo se usa de outra pessoa ou do serviço)

5. Explique quando e como ocorreu a introdução do computador na sua vida pessoal?

6. Você utilizou o computador na sua formação acadêmica, na sua formação no ensino fundamental e nas formações continuadas? Como era esta utilização? Quais recursos computacionais eram utilizados?

FOCO 3 - USO DO COMPUTADOR NO TRABALHO DOCENTE (Como que $o$ ajuda?).

7. Desde que ano é professor?

8. Qual disciplina ministra? É em escola pública ou particular?

9. Quando você começou a utilizar o computador nas atividades profissionais? Como foi este uso no início? O que o motivou a esta utilização?

10. O que você pensa sobre o uso do computador em seu trabalho como professor? (na aula e fora dela). Qual recurso computacional utiliza? Quais atividades realizam? Acessa acervos, programas de ensino, faz arquivos ou outros tipos de utilização? 
11. Você troca algum tipo de informação com o uso do computador com outros professores de forma a auxiliar no seu trabalho docente?

12. Você se relaciona com seus alunos através do computador?

13. De que maneira o computador ajuda no seu trabalho como professor e auxilia em suas atividades docentes? Dê exemplos? Sua aula seria diferente sem o uso do computador?

14. Na sua compreensão, qual o papel do aluno nas possíveis utilizações do computador?

\section{FOCO 4 - CONTRIBUIÇÃO DE APRENDIZAGEM PARA O TRABALHO DOCENTE}

15. Dê exemplos de atividades que o aluno desenvolve com o computador?

16. Explique se com o uso do computador você ensina melhor e se cria oportunidades de aprendizagem para os alunos?

17. O que você aprendeu e o que lhe trouxe de novo o uso do computador?

18. O que o professor aprende com o aluno quando utiliza o computador em suas aulas?

19. Com a ausência dele seria diferente? Quais dificuldades teriam? 
ANEXO 2

ANÁLISE DOS DADOS DAS QUATRO ENTREVISTAS REALIZADAS E DAS OBSERVAÇÕES EM SALA DE AULA.

SABERES DOCENTES PEDAGÓGICOS COMPUTACIONAIS (SDPC) de:

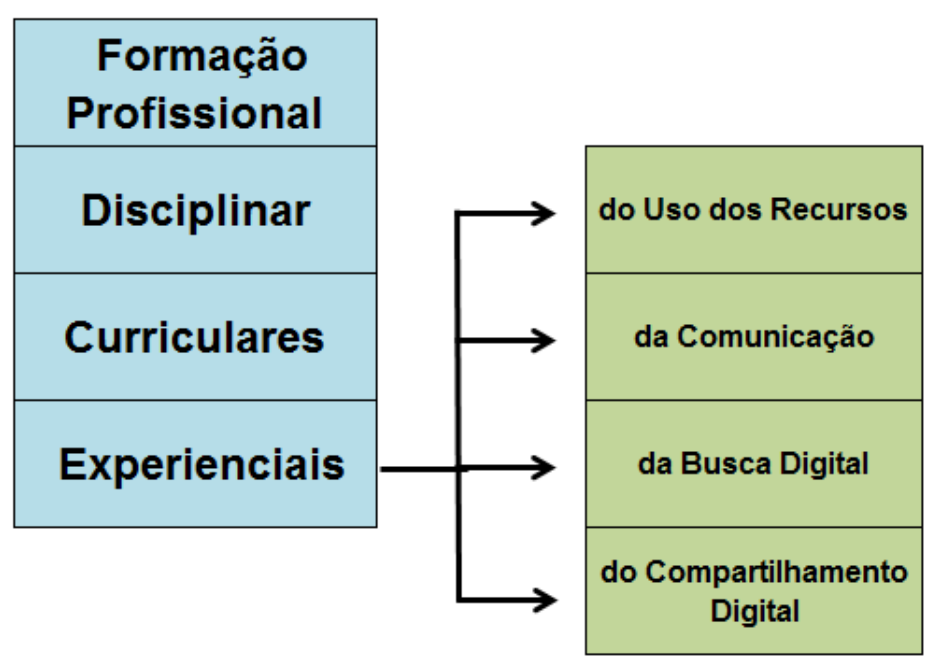

\begin{tabular}{|cc|}
\hline \multicolumn{2}{|c|}{ RECURSOS DIDATICOS(Rec Did) } \\
\hline$>$ Modelagem Computacional & MdC \\
$>$ Multimídia Computacional & MtC \\
$>$ Internet & Int \\
\hline
\end{tabular}

(Quadro de Siglas) 


\begin{tabular}{|c|c|c|}
\hline SABER & $\begin{array}{c}\text { 5.1.1 SDPC FORMAÇÃO } \\
\text { PROFISSIONAL }\end{array}$ & $\begin{array}{c}\text { "por que você diz isso?" } \\
\text { e "por que você faz } \\
\text { isso?" }\end{array}$ \\
\hline Não há saber & $\begin{array}{l}\text { - (...) enquanto aluna da graduação comecei a } \\
\text { me envolver com o computador, até então eu } \\
\text { nunca tinha tido um, e ele foi mais assim... } \\
\text { para iniciar trabalhos na universidade... na } \\
\text { minha formação em Física. Eu tinha alguns } \\
\text { dados de laboratório, eu pegava estes dados } \\
\text { com o computador, daí, depois o computador } \\
\text { se tornou útil, na escrita de relatórios, que } \\
\text { facilitava a formatação, em questão de fazer } \\
\text { cópias, de fazer gráficos. Inicialmente a gente } \\
\text { começou com o Excel, depois foi pra outros } \\
\text { (...) (Prof. 2) } \\
\text { MtC } \\
\text { - Os computadores estavam iniciando na } \\
\text { Universidade de São Paulo e desde aquela } \\
\text { época eu já comecei a trabalhar com bancos } \\
\text { de dados, programação, desenvolvimento de } \\
\text { projeto... (Prof. 3) } \\
\text { MtC } \\
\text { MtC/MdC } \\
\text { - Na carreira profissional eu comecei a utilizar } \\
\text { programas para o Grupo de Pesquisas onde a } \\
\text { gente trabalhava na especialização em Física } \\
\text { Médica (Prof. 3) } \\
\text { Mniversidade, desenvolvendo } \\
\text { Mata }\end{array}$ & $\begin{array}{c}\text { Dão } \\
\text { Não há } \\
\text { argumentações que } \\
\text { indiquem um saber, } \\
\text { apenas indícios do } \\
\text { início do uso de } \\
\text { Artefatos } \\
\text { Computacionais na } \\
\text { sua vida pessoal e } \\
\text { profissional. }\end{array}$ \\
\hline
\end{tabular}

\begin{tabular}{|c|c|c|}
\hline SABER & 5.1.2 SDPC DISCIPLINAR & $\begin{array}{c}\text { "por que você diz } \\
\text { isso?" e "por que você } \\
\text { faz isso?" }\end{array}$ \\
\hline \multirow[t]{2}{*}{ Não há saber } & $\begin{array}{l}\text { - Na Licenciatura de Física existia uma } \\
\text { matéria chamada "Introdução à Computação" } \\
\text { e aprendíamos a programar... foi assim que } \\
\text { comecei a usar o computador... (Prof. 1) } \\
\text { MtC/MdC }\end{array}$ & \multirow{2}{*}{$\begin{array}{c}\text { Não são } \\
\text { argumentações que } \\
\text { caracterizem um } \\
\text { saber, mas } \\
\text { demonstram que } \\
\text { nesta fase os } \\
\text { entrevistados }\end{array}$} \\
\hline & $\begin{array}{l}\text { - O primeiro contato com o computador foi na } \\
\text { graduação de Física que terminei em } 94 . \\
\text { Existia uma matéria de linguagem de } \\
\text { programação na qual tínhamos que fazer uso } \\
\text { do computador... (Prof. 2) }\end{array}$ & \\
\hline
\end{tabular}




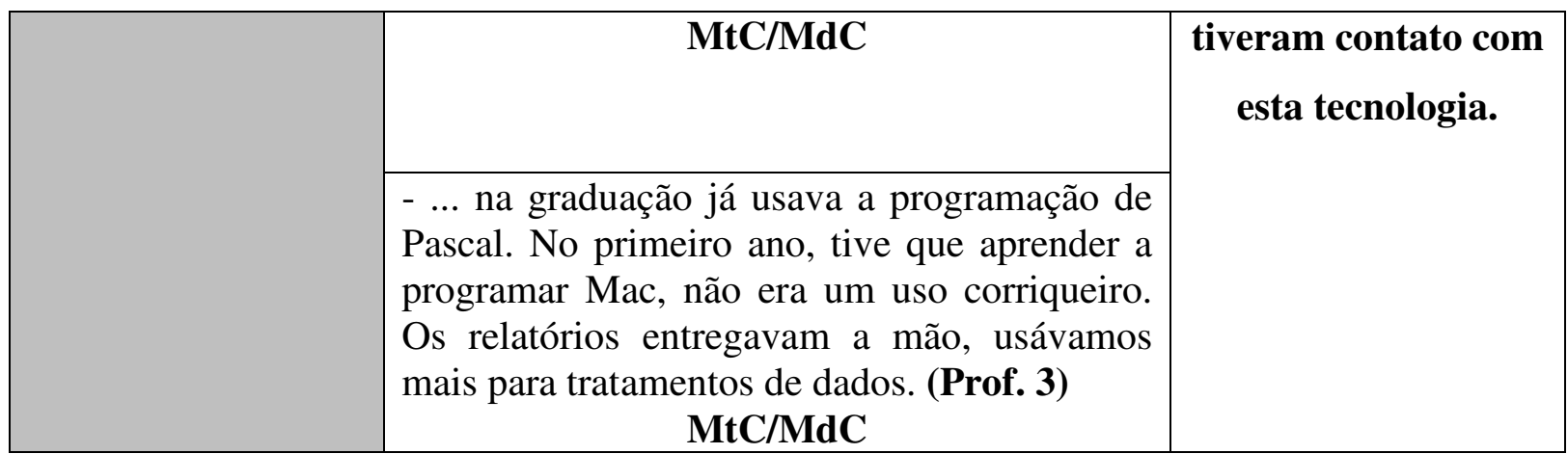

\begin{tabular}{|c|c|c|}
\hline SABER & 5.1.3 SDPC CURRICULARES & $\begin{array}{c}\text { "por que você diz } \\
\text { isso?" e "por que você } \\
\text { faz isso?" }\end{array}$ \\
\hline Não há saber & $\begin{array}{l}\text { - (na escola onde lecionava) ...tive contato com } \\
\text { alguns software que davam conta de apresentar } \\
\text { através de animações, alguns fenômenos que eram } \\
\text { de ciências... O aluno conseguia visualizar... Ele } \\
\text { podia fazer modificações, então, eu criei um } \\
\text { roteiro para trabalhar com o software ... Era o de } \\
\text { óptica geométrica (Prof.1) } \\
\text { MdC }\end{array}$ & $\begin{array}{c}\text { Não há } \\
\text { argumentações que } \\
\text { indiquem um saber, } \\
\text { apenas indícios de } \\
\text { distribuição de } \\
\text { softwares } \\
\text { pertencentes a } \\
\text { algum programa de } \\
\text { distribuição de } \\
\text { material didático do } \\
\text { governo. }\end{array}$ \\
\hline
\end{tabular}

\begin{tabular}{|c|c|c|}
\hline SABER & $\begin{array}{l}\text { 5.2 SPDC EXPERIENCIAIS DO USO DOS } \\
\text { RECURSOS }\end{array}$ & $\begin{array}{c}\text { “por que você diz } \\
\text { isso?" e "por que você } \\
\text { faz isso?" }\end{array}$ \\
\hline $\begin{array}{c}\text { 5.2.1 Saber que: “Os } \\
\text { alunos apresentam } \\
\text { graus bem } \\
\text { diferenciados de } \\
\text { familiaridade no } \\
\text { uso dos recursos } \\
\text { computacionais.”. }\end{array}$ & $\begin{array}{l}\text {-... a gente tem dois tipos de alunos, na verdade } \\
\text { três: aqueles alunos que têm muita empatia pelo } \\
\text { computador, aqueles que têm muito medo do } \\
\text { computador e aqueles alunos que tem o computador } \\
\text { como uma coisa legal, que ele usa, mas para ele não } \\
\text { é uma coisa essencial.... Por conta disso, é que eu } \\
\text { trabalho com duplas, porque é assim, tem um } \\
\text { aluno que sabe um pouco mais do que o outro e } \\
\text { consegue mostrar para o seu parceiro como é } \\
\text { que faz, e esse consegue fazer, com essas trocas } \\
\text { os dois conseguem alcancar melhor or } \\
\text { conhecimento (Professor1). } \\
\text { MtC/MdC/I }\end{array}$ & $\begin{array}{l}\text { Porque trabalhando } \\
\text { com duplas o aluno } \\
\text { que sabe um pouco } \\
\text { mais consegue } \\
\text { mostrar ao seu } \\
\text { parceiro como se faz. }\end{array}$ \\
\hline
\end{tabular}


Alguns alunos gostam e se identificam com o computador, gostam de trabalhar com ele, sabem manusear... Entendeu? Conhecem muita coisa de computação. Para esses alunos é fácil pegar o computador e pesquisar qualquer assunto, porque eles conhecem como se trabalha com a máquina. (Professor 1).

MtC/I

- As ferramentas são as mesmas, a diferença é que eles têm mais facilidades de baixar um vídeo, um arquivo, enfim, possuem mais facilidades. Coisas que tenho que fazer com um longo caminho, eles têm mais habilidades, ou seja, usam recursos diretos que o computador oferece e que por muitas vezes desconheco. (Professor. 4)

\begin{tabular}{l}
\hline MtC/I \\
- Para mim, os alunos têm muito mais agilidade de \\
lidar com os equipamentos, com os problemas que \\
eles apresentam, com muito mais facilidade que \\
nós, pois eles são de uma nova geracão que tem \\
um contato maior com os computadores do que \\
a nossa, por isso aprendo muito com eles. \\
(Professor 3). MtC/I
\end{tabular}

- Então, tem alguns alunos que têm medo, você pede para ele escrever um texto no Word ele não sabe formatar, não sabe isso, não sabe aquilo, ou imprime o negócio com data e tudo. Então é assim, tem algumas coisas que o aluno ainda não desenvolveu habilidade para trabalhar, e ai ele fica temeroso com aquilo. (Professor 1).

MtC

\section{Porque para esses}

alunos é fácil pegar 0 computador $\mathbf{e}$ pesquisar qualquer assunto; eles conhecem como se trabalha com a máquina.

Porque eles têm mais habilidades, ou seja, usam recursos diretos que o computador oferece e que por muitas vezes 0 professor desconhece.

Porque eles são de uma nova geração que tem um contato maior com os computadores do que a dos professores, por isso aprende-se muito com eles.

Porque os alunos que não desenvolveram

habilidades de trabalhar com o computador ficam

temerosos.
5.2.2 Saber que: “ $O$ uso dos recursos computacionais auxilia a
Quando fazemos seminários, apresentamos com cartazes, com maquetes ou com o PowerPoint, que entra como uma ferramenta ai, estes recursos ajudam o entendimento que ele tem, ou ajudam na producão de um texto que ele vai apresentar (Professor 1). $\mathrm{MtC} / \mathrm{MdC} / \mathrm{I}$
Porque estes recursos ajudam 0 entendimento, na produção de um texto que se vai apresentar. 


\begin{tabular}{|c|c|c|}
\hline \multirow[t]{3}{*}{$\begin{array}{c}\text { aprendizagem dos } \\
\text { alunos" }\end{array}$} & $\begin{array}{l}\text { - Não uso sempre o PowerPoint. Nesta aula em } \\
\text { particular, usei por dois motivos: para } \\
\text { sintetizar os conceitos que estamos } \\
\text { trabalhando, porque é melhor do que ficar } \\
\text { escrevendo na lousa...; e } \\
\text { tínhamos uma simulacão e este recurso } \\
\text { permite apresentar de uma forma mais } \\
\text { prática os espectros de alguns elementos } \\
\text { químico de emissão e absorção. (Professor } 2 \text { - } \\
\text { Observações Sala de Aula). } \\
\text { MtC/MdC } \\
\end{array}$ & \begin{tabular}{|c} 
Porque os alunos \\
ficam bem mais \\
motivados em \\
trabalhar com o \\
computador do que \\
com livros e revistas, \\
mais até mesmo do que \\
com atividade \\
experimental.
\end{tabular} \\
\hline & $\begin{array}{l}\text {.. Porque não temos algo prático para ser o } \\
\text { norte da atividade ... } 0 \text { vídeo vai fazer uma } \\
\text { abertura para comecarmos a discussão. } \\
\text { (Professor } 2-\text { Prática sala de aula). } \\
\text { MtC }\end{array}$ & $\begin{array}{l}\text { Porque o vídeo } \\
\text { permite fazer uma } \\
\text { abertura para começar } \\
\text { discussões. }\end{array}$ \\
\hline & $\begin{array}{l}\text {... é muito mais pobre sem visualização o aluno } \\
\text { precisa imaginar mais, com a animacão, os } \\
\text { alunos conseguem visualizar melhor e } \\
\text { compreender as diferencas. (Professor } 4- \\
\text { Prática sala de aula). } \\
\text { MdC }\end{array}$ & $\begin{array}{l}\text { Porque com a } \\
\text { animação os alunos } \\
\text { conseguem visualizar } \\
\text { melhor e compreender } \\
\text { as diferenças. }\end{array}$ \\
\hline
\end{tabular}

5.2.3 Saber que: "A
ação docente é
importante para
orientar e
direcionar os
alunos para buscar
e selecionar
conteúdos

Explicamos os endereços, as siglas, as informações confiáveis. Explicamos as diferenças entre sites confiáveis e os nãos confiáveis, o que é o Wikipedia, até que ponto é interessante, mostrando que qualquer um pode colocar informacõos lá e que podemos contribuir, mostrando toda a importância da navegação. (Professor 3).
Porque qualquer um pode colocar informações e contribuir, mostrando toda a importância da navegação. 


\begin{tabular}{|c|c|c|}
\hline \multicolumn{3}{|l|}{$\begin{array}{c}\text { confiáveis na } \\
\text { internet." }\end{array}$} \\
\hline \multirow{5}{*}{$\begin{array}{l}\text { 5.2.4 Saber que: “Os } \\
\text { recursos } \\
\text { computacionais } \\
\text { ampliam as } \\
\text { possibilidades das } \\
\text { ações didáticas.” }\end{array}$} & $\begin{array}{l}\text { - O computador é uma ferramenta que amplia as } \\
\text { possibilidades didáticas. Com o computador } \\
\text { conectado à internet existem muito mais } \\
\text { possibilidades do que sem ele, aumentando os } \\
\text { recursos. Com isso, mais alunos conseguem } \\
\text { entender no meio de uma coisa e outra. (Professor } \\
\text { 4). } \\
\text { I }\end{array}$ & $\begin{array}{c}\text { Porque consegue se } \\
\text { organizar melhor; ser } \\
\text { mais sucinto; adequar } \\
\text { melhor o tempo. } \\
\text { Porque com o } \\
\text { computador } \\
\text { conectado a internet } \\
\text { existe muito mais } \\
\text { possibilidades do que } \\
\text { sem ele, aumentando } \\
\text { os recursos. }\end{array}$ \\
\hline & $\begin{array}{l}\text { - Nas simulações, o aluno interage com as } \\
\text { atividades, faz cálculos precisos dos experimentos, } \\
\text { analisa o que ele viu na simulação com o real... } \underline{\mathbf{0}} \\
\text { computador pode dinamizar as minhas aulas } \\
\frac{\text { substituindo a lousa... (Professor } 2 \text { ). }}{\text { MtC/MdC }}\end{array}$ & $\begin{array}{l}\text { Porque o computador } \\
\text { pode dinamizar as } \\
\text { aulas substituindo a } \\
\text { lousa. }\end{array}$ \\
\hline & $\begin{array}{l}\text { - Hoje eu não consigo ver minhas aulas sem o } \\
\text { computador em sala de aula, se não tivesse eu teria } \\
\text { que começar do zero, seria menos autônoma, ou } \\
\text { seja, dependeria mais de materiais de outros } \\
\text { profissionais, como livros didáticos, orientações, } \\
\text { materiais do estado. (Professor 4). } \\
\text { MtC/MdC/I }\end{array}$ & $\begin{array}{l}\text { Porque dá autonomia } \\
\text { ao professor, } \\
\text { dependendo menos de } \\
\text { materiais de outros } \\
\text { profissionais. }\end{array}$ \\
\hline & $\begin{array}{l}\text { - .. Agora para as demais aulas em geral, se não } \\
\text { fosse de Laboratório de Investigação, mudaria } \\
\text { talvez, porque teria que produzir um número } \\
\text { maior de material de apoio impresso, } \\
\text { eventualmente uma utilização maior da lousa } \\
\text { com o giz... essa seria a grande diferenca. } \\
\text { (professor 2). } \\
\text { MtC/MdC/I }\end{array}$ & $\begin{array}{c}\text { Porque reduz a } \\
\text { produção de um } \\
\text { número maior de } \\
\text { material de apoio } \\
\text { impresso; uma } \\
\text { utilização menor da } \\
\text { lousa e giz. }\end{array}$ \\
\hline & $\begin{array}{l}\text { - Como poderia visitar locais como a profundeza } \\
\text { dos mares, onde eu não poderia estar indo, ele me } \\
\text { propicia esta possibilidade. (Professor } 1) . \\
\text { I }\end{array}$ & $\begin{array}{l}\text { Porque pode visitar } \\
\text { locais como a } \\
\text { profundeza dos }\end{array}$ \\
\hline
\end{tabular}


(...) me propicia mais tempo, pois para um professor, o tempo é uma coisa muito preciosa. Em segundos eu consigo buscar alguns materiais. Em livros didáticos, necessariamente não teria a mesma facilidade, pode ajudar os meus alunos, mas através do computador consigo adaptar os conteúdos para que fiquem de acordo com as necessidades de meus alunos, acrescentando ou tirando algumas coisas e aos poucos, vai ganhando a minha cara e nos anos seguintes vão sendo adaptados com o que já tenho, de acordo com a nova turma... (Professor 4).

$\mathrm{MtC} / \mathrm{I}$

Você tem programas que o aluno pode mudar o peso de algumas coisas, mas não é a mesma coisa de você poder pegar, poder mexer, entendeu? É diferente de pegar o multímetro e poder ir medir a voltagem na sala do que ter isso representado no computador. Mas é interessante porque para criancas muito pequenas, você não vai dar um multímetro na mão porque não sabe onde ele vai colocar... (professor 1).

MtC/MdC/I mares.

Porque consegue

adaptar os conteúdos

para que fiquem de acordo com as

necessidades dos alunos.

Porque para crianças muito pequenas não vai se dar um multímetro na mão, pois não sabe onde ele vai colocar.
5.2.5 Saber que: “O uso pessoal do computador influência o uso profissional."
Quando temos pouca intimidade com a tecnologia, fazemos pouco uso. Tem pessoas que tem intimidade zero com a tecnologia, principalmente as pessoas mais velhas as quais são resistentes. Quanto mais essa tecnologia esta incorporada no seu dia-a-dia, mais uso você vai fazer dela. Essa coisa do pessoal e do profissional acaba se encontrando. (Professor 3).

\section{Porque quanto mais} essa tecnologia está incorporada no dia-adia, mais uso se faz dela, o pessoal e do profissional acaba se encontrando.

\begin{tabular}{|c|c|c|}
\hline $\begin{array}{l}\text { 5.2.6 Saber que: } \\
\text { "Há alternativas } \\
\text { para substituir e } \\
\text { adequar o uso dos } \\
\text { recursos }\end{array}$ & $\begin{array}{l}\text { - É assim em sites extremamente confiáveis, por } \\
\text { exemplo: da Nasa, eu estava pronta para mostrar } \\
\text { uma coisa em um determinado dia, olhei estava } \\
\text { tudo certo no dia anterior. Entrei no dia e você diz: } \\
\text { nossa logo o site da Nasa esta fora do ar. Então são } \\
\text { coisas que você acaba ficando na mão. Você tem } \\
\frac{\text { que ter sempre um plano B. (Professor } 1 \text { ). }}{\text { I }}\end{array}$ & $\begin{array}{c}\text { Porque acaba } \\
\text { deixando na mão, tem } \\
\text { que se ter sempre um } \\
\text { plano } B .\end{array}$ \\
\hline
\end{tabular}




\begin{tabular}{|c|c|c|}
\hline computacionais em & & \\
caso de panes & & Porque tem que ter \\
digitais ou do não & Eu tenho que ter outras alternativas para & outras alternativas \\
funcionamento & minimizar os problemas com o computador & para minimizar os \\
adequado dos & MtC/MdC/I & problemas com o \\
Artefatos & & computador. \\
Computacionais. & & \\
\hline
\end{tabular}

\begin{tabular}{|c|c|c|}
\hline SABER & $\begin{array}{c}\text { 5.3 SDPC EXPERIENCIAIS DA } \\
\text { COMUNICAÇÃO }\end{array}$ & $\begin{array}{c}\text { "por que você diz isso?" } \\
\text { e "por que você faz } \\
\text { isso?" }\end{array}$ \\
\hline $\begin{array}{l}\text { 5.3.1 Saber que: "A } \\
\text { comunicação pela } \\
\text { internet é um meio } \\
\text { de comunicação }\end{array}$ & $\begin{array}{l}\text { - Eles podem me encaminhar trabalhos por email ... } \\
\text { por etapas e a gente vai corrigindo, vai devolvendo } \\
\text { para eles antes do trabalho final. Então, tanto por } \\
\text { email, como nas redes sociais, a gente troca } \\
\text { informação com o grupo de alunos dessa e de } \\
\text { outras escolas. (Professor } 2) . \\
\text { MtC/I }\end{array}$ & $\begin{array}{l}\text { Porque tanto por } \\
\text { email, como nas redes } \\
\text { sociais, se faz troca de } \\
\text { informação com grupo } \\
\text { de alunos. }\end{array}$ \\
\hline $\begin{array}{c}\text { que facilita a } \\
\text { interação entre } \\
\text { professores e } \\
\text { alunos na troca de } \\
\text { informações, envio } \\
\text { e } \\
\text { compartilhamento } \\
\text { de trabalhos". }\end{array}$ & $\begin{array}{l}\text { - (...) o email embora seja uma coisa normal, } \\
\text { básica, hoje em dia é uma coisa muito importante } \\
\text { pois as informações chegam muito rápido, você } \\
\text { abre o email já tem comunicado, e aqui como } \\
\text { trabalhamos muito em grupo ajuda, pois se algum } \\
\text { colega tem alguma dúvida, nós nos ajudamos e as } \\
\text { repostas chegam muito rápido. O email é uma } \\
\text { ferramenta básica e facilita muito para a } \\
\text { interacão entre os professores e alunos para o } \\
\text { funcionamento da escola. (Professor 3). } \\
\text { I }\end{array}$ & $\begin{array}{l}\text { Porque o email é uma } \\
\text { ferramenta básica e } \\
\text { facilita muito para a } \\
\text { interação entre os } \\
\text { professores e alunos } \\
\text { para o funcionamento } \\
\text { da escola. }\end{array}$ \\
\hline
\end{tabular}

\begin{tabular}{|c|c|c|}
\hline $\mathbf{S A}$ & $\begin{array}{l}\text { 5.4 SDPC EXPERIENCIAIS DA BUSCA } \\
\text { DIGITAL }\end{array}$ & $\begin{array}{c}\text { "por que você diz isso?" } \\
\text { e "por que você faz } \\
\text { isso?" }\end{array}$ \\
\hline \multirow{2}{*}{$\begin{array}{l}\text { 5.4.1 Saber que: } \\
\text { “Com o uso da } \\
\text { internet, existem } \\
\text { alunos que se } \\
\text { dispersam dos }\end{array}$} & $\begin{array}{l}\text {-... a gente tem sempre aquele aluno, que sai do } \\
\text { site que foi pedido para fazer coisas que não foram } \\
\text { pedidas. Então ele vai, entrar no msn dele.... } \\
\text { porque o UCA, por exemplo, ele não está } \\
\text { bloqueado para isso. (Professor 1). } \\
\text { I }\end{array}$ & $\begin{array}{l}\text { Porque o aluno vai } \\
\text { acessar o msn dele. }\end{array}$ \\
\hline & $\begin{array}{l}\text { - ... o computador pode desviar a atencão } \\
\text { daqueles alunos que vão olhar outro site, vão } \\
\text { ver isso, aquilo... (Professor } 1) .\end{array}$ & $\begin{array}{l}\text { Porque pode desviar a } \\
\text { atenção de alunos que }\end{array}$ \\
\hline
\end{tabular}




\begin{tabular}{|c|c|c|}
\hline $\begin{array}{c}\text { assuntos } \\
\text { pedagógicos e que }\end{array}$ & $\mathbf{I}$ & acessam outros sites. \\
\hline $\begin{array}{c}\text { não analisam as } \\
\text { informações } \\
\text { pesquisadas". }\end{array}$ & $\begin{array}{l}\text { - ...me entrega a página inteira, eu lhe faço uma } \\
\text { pergunta e se ele não conseguir encontrar a } \\
\text { resposta, é porque realmente ele não pesquisou, } \\
\text { ele pegou a primeira página que apareceu } \\
\text { aquele nome, colocou o seu e me entregou. } \\
\text { (Professor 1). } \\
\text { MtC/I }\end{array}$ & $\begin{array}{l}\text { Porque o aluno não } \\
\text { pesquisa, ele pega a } \\
\text { primeira página que } \\
\text { aparece com o assunto } \\
\text { pedido, coloca seu nome } \\
\text { e entrega }\end{array}$ \\
\hline
\end{tabular}

\begin{tabular}{|c|c|c|}
\hline \multirow{4}{*}{$\begin{array}{c}\text { 5.4.2 Saber que a } \\
\text { internet possui } \\
\text { diversas fontes de } \\
\text { informações que } \\
\text { devem ser } \\
\text { selecionadas } \\
\text { visando o objetivo } \\
\text { pedagógico. }\end{array}$} & $\begin{array}{l}\text { - O computador demanda uma nova habilidade que } \\
\text { é justamente essa, selecionar, pois você tem uma } \\
\text { gama gigante de informações que aparece a sua } \\
\text { frente muito rápida e você tem que saber lidar } \\
\text { com isso, como lidar com informacões tão } \\
\text { rápidas, direcionando os alunos para sites } \\
\text { confiáveis ... analisar, selecionar e sintetizar } \\
\text { para depois produzir um documento meu. } \\
\text { (Professor 3). }\end{array}$ & $\begin{array}{l}\text { Porque tem que saber } \\
\text { lidar com informações } \\
\text { que são tão rápidas, } \\
\text { direcionando os } \\
\text { alunos para sites } \\
\text { confiáveis. }\end{array}$ \\
\hline & $\begin{array}{l}\text { - Para buscar alguns conceitos específicos que me } \\
\text { faltam, posso recorrer a internet que me oferece } \\
\text { múltiplas fontes. (Professor 3). } \\
\text { I }\end{array}$ & $\begin{array}{l}\text { Porque a internet } \\
\text { oferece múltiplas } \\
\text { fontes. }\end{array}$ \\
\hline & $\begin{array}{l}\text { - Às vezes, levamos os alunos às bibliotecas, } \\
\text { mostramos o que tem, mas é difícil comparar, pois } \\
\text { na biblioteca às vezes tem uma ou duas fontes } \\
\text { enquanto na internet tem trinta ou muito mais } \\
\text { a cada minuto, é muito maior a quantidade de } \\
\text { informacões. (Professor 3). } \\
\text { I }\end{array}$ & $\begin{array}{l}\text { Porque na biblioteca } \\
\text { às vezes tem uma ou } \\
\text { duas fontes enquanto } \\
\text { na internet tem trinta } \\
\text { ou muito mais a cada } \\
\text { minuto, é muito maior } \\
\text { a quantidade de } \\
\text { informações. }\end{array}$ \\
\hline & $\begin{array}{l}\text {-... eles precisam saber usar as ferramentas como } \\
\text { fonte de ajuda e ter um olhar crítico para as } \\
\text { informacões que pegam da internet..., saber que } \\
\begin{array}{l}\text { eles podem receber informações importantes. } \\
\text { (Professor 3). }\end{array}\end{array}$ & $\begin{array}{c}\text { Porque tem que ter } \\
\text { um olhar crítico para } \\
\text { as informações que se } \\
\text { pegam na internet. }\end{array}$ \\
\hline
\end{tabular}




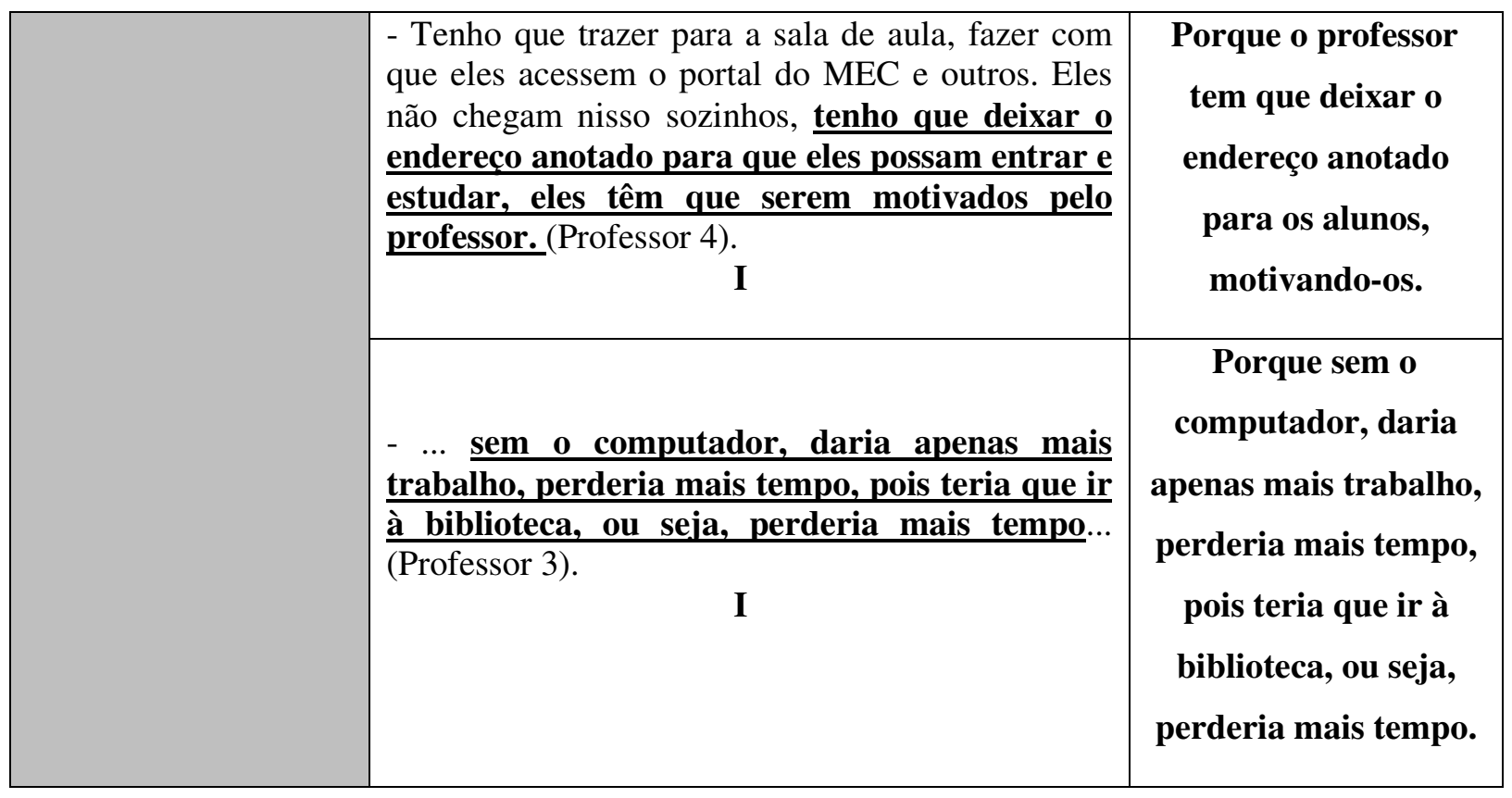

\begin{tabular}{|c|c|c|}
\hline SABER & $\begin{array}{c}\text { 5.5 SDPC EXPERIENCIAIS DO } \\
\text { COMPARTILHAMENTO DIGITAL }\end{array}$ & $\begin{array}{c}\text { "por que você diz isso?" } \\
\text { e "por que você faz } \\
\text { isso?" }\end{array}$ \\
\hline $\begin{array}{c}\text { 5.5.1 Saber } \\
\text { compartilhar } \\
\text { arquivos que julgar } \\
\text { de interesse para } \\
\text { professores e } \\
\text { alunos. }\end{array}$ & $\begin{array}{l}\text { - (Dropbox) É uma caixinha que você coloca nas } \\
\text { nuvens. Na verdade quem administra é um } \\
\text { professor por série. Você tem uma senha para } \\
\text { poder acessar e postar, salvar dentro desse espaço } \\
\text { conteúdos que podem ser acessados por todos.... } \\
\text { nós professores, colocamos os documentos que } \\
\text { acreditamos ser importantes: um artigo, uma } \\
\text { experiência, enfim, o que o professor achar ser } \\
\text { interessante e bacana, ele pode disponibilizar } \\
\text { nesta pasta... (Professor 3) } \\
\text { MtC/I }\end{array}$ & $\begin{array}{l}\text { Porque os professores } \\
\text { colocam os } \\
\text { documentos que } \\
\text { acreditam ser } \\
\text { importantes: um } \\
\text { artigo, uma } \\
\text { experiência; de } \\
\text { qualquer lugar pode } \\
\text { acessar, compartilhar } \\
\text { arquivos entre } \\
\text { professores e alunos. }\end{array}$ \\
\hline
\end{tabular}


De qualquer lugar posso acessar, posso compartilhar os arquivos entre os professores e os alunos, às vezes correções de trabalhos interdisciplinares, disponibilizar alguns arquivos para os alunos. Esse recurso não tem custo, apenas um limite de arquivos de 3G. (Professor 4).

$\mathrm{MtC} / \mathrm{I}$ 